\title{
Wills of Movables in American International Conflicts Law: A Critique of the Domiciliary "Rule"
}

\author{
Athanassios N. Yiannopoulos*
}

The inheritance laws of a state or country are designed to apply to successions involving predominantly domestic contacts. Successions with significant foreign contacts are ordinarily, on grounds of policy, referred to foreign law in accordance with choice-of-law rules. ${ }^{1}$ Place of execution of a will, situs of the personal property, and domicile and nationality of the testator are taken into consideration by the legal systems of other countries; but in the American common law the domicile of the testator is supposed to be the only significant connecting factor. Accordingly, the Restatement of Conflict of Lawes lays down, ${ }^{2}$ all writers in the field concur in, ${ }^{3}$ and the langnage of several liundreds of judicial decisions seems to support the proposition that testamentary succession to personal property is governed by the law of the testator's domicile at death. ${ }^{4}$

* Dipl. in Law, University of Thessaloniki, 1950; M.C.M. University of Chicago, 1954; L.L.M., J.S.D., University of California, 1956. Associate Professor of Conparative Law, Louisiana State Univesity. This article was submitted to the faculty of the University of California School of Law in partial satisfaction of the requirements of the degree, Doctor of the Science of Law. The research and writing were made possible by a Walter Perry Johnson Research Graduate Fellowship in Law (1954-1955) and a University of California Graduate Fellowship in Law (1955-1956). The author wishes to express his thanks to Dean Prosser, to the chairman and nemibers of his committee-Professors Ehrenzweig, Barrett, Ferrier, Harper and Riesenfeld -and to the entire faculty for the encouragenent and assistance offered him during his studies at Berkeley.

1 For the policies underlying the reference to foreign law see generally FaICONBRDGE, CONFLICT OF LAwS 10-49 (1954).

2 Restateanent, Conflict of Laws $\$ \S 301,303,306-08$ (1934).

3 E.g., 2 Beare, Conelict of Laws 1026-41 (1935); Brestauer, Private Internationat LaW of Succession 86-199 (1937); Cheshire, Private Internationac Law 519 (1952); DiceY, Conflict of Laws 818 (1949); FaICONBRDGE, Conflict of LaWs 528-41 (1954); Goodrich, Confuict of Laws 512-18 (1949); Story, Confuict of Laws 391-490 (1st ed. 1834); Strumberg, Conflict of Laws 409-36 (1951); Westlake, Prtvate International LAW 111-62 (1912).

4 See, e.g., the following international cases: Dammert v. Osborn, 140 N.Y. 30,35 N.E. 407 (1893) ; Matter of Lachenmeyer, 144 Misc. 678, 258 N.Y. Supp. 641 (Surr. Ct. 1928) ; Houghton v. Brantingham, 86 Conn. 630,86 Atl. 664 (1913) ; Harrison v. Nixon, 34 U.S. (9 Pet.) 483 (1835); In re Fricke's Will, 202 N.Y. Supp. 906 (Surr. Ct. 1924); Matter of Coudert, 92 Misc. 109, 155 N.Y. Supp. 145 (Surr. Ct. 1915); In re Kapell's Will, 120 N.Y.S.2d 52 (Sup. Ct. 1953); Harding v. Schapiro, 120 Md. 541, 87 Atl. 951 (1913); Matter of Hollins, 79 Misc. 200, 139 N.Y. Supp. 713 (Surr. Ct. 1913); New York Life Ins. and Trust Co. v. Viele, 161 N.Y. 11, 55 N.E. 311 (1899); Cruger v. Phelps, 21 Misc. 252, 47 N.Y. Supp. 61 (Sup. Ct. 1897); In re Feuermann's Will, 47 N.Y.S.2d 738 (Surr. Ct. 1944); Matter of Moran, 180 Misc. 469, 39 N.Y. S.2d 929 (Surr. Ct. 1943) ; In re Harwood, 104 Misc. 653, 172 N.Y. Supp. 296 (Surr. Ct. 1918); Palmer v. Bradley, 142 Fed. 193 (N.D. Mll. 1905), affd, 154 Fed. 311 (1907), cert. denied, 209 U.S. 548 (1908) ; Robert's Succession, 2 Rob. 427 (La. 1842); Estate of Yuill, 109 Misc. 465, 178 N.Y. Supp. 871 (Surr. Ct. 1919); In re Schneider's Estate, 96 N.Y.S.2d 652 (Surr. Ct. 1950), aff $d, 100$ N.Y.S.2d 371, 82 N.E.2d 29. 
Actually, a re-examination of the case law shows that: (1) A large number of decisions declaring that domiciliary law governs succession to movables do not involve a choice of law problem but rather the analytically distinct situation ${ }^{5}$ in which recognition of a foreign judgment is sought and such recognition is afforded or denied according to the forum notions of "indirect" jurisdiction and res judicata rather than according to choice-oflaw rules. ${ }^{6}(2)$ The domiciliary rule is unnecessarily invoked-a mere surplusage -in cases involving succession to real property ${ }^{7}$ or administration. ${ }^{8}$ (3) In most instances the situs of the personalty and domicile of the decedent are within the forum jurisdiction and the decisions invoking the law of the domicile could be rationalized as based on either the law of the situs or that of the forum. ${ }^{9}$ (4) While lip service is paid to the rule, other than domiciliary law is actually applied in a large number of cases by means of several devices; these include the presumption of identity of the foreign law with that of the forum, the invocation of the testator's intention that some particular law be applied, the localization of the domicile at the situs of the personal property, and the acceptance of renvoi from the domiciliary law. ${ }^{10}$ (5) Finally, in several instances the applicability of the rule is questioned and other than domiciliary law openly applied. ${ }^{11}$

Accordingly, it is the thesis of this article that the domiciliary rule as such is not supported by case authority, at least with respect to cases involving international conflicts; ${ }^{12}$ testamentary succession to personal prop-

\footnotetext{
5 See Hopkins, The Extraterritorial Effect of Probate Decrees, 53 Yate L.J. 221, 230 (1944).

G.g., Williams v. Saunders, 45 Tenn. (5 Cold.) *60 (1867) ; Freeman's Appeal, $68 \mathrm{~Pa} .151$ (1871) ; Jacobs v. Willis, 147 Tenn. 539, 249 S.W. 815 (1923); Trimble v. Dzieduzyiki, 57 How. Pr. 208 (N.Y. 1878); Manuel v. Manuel, 13 Ohio 458 (1862) (cited in 2 BEALE, Conflict or LAws $1034 \mathrm{n} .5$, for the proposition that the law of the testator's domicile governs succession). For the distinction between "direct" and "indirect" jurisdiction see note 24 infra.

7 E.g., Singleton v. St. Louis Union Trust Co., 191 S.W.2d 143 (Texas Ct. of Civ. App. 1945); Seaton v. Seaton, 184 Va. 180, 34 S.E.2d 236 (1945); Shaw v. Grimes, 187 Ky. 250, 218 S.W. 447 (1919) (cited in 2 BEALE, Conflict of Laws 1035 n.3).

8 E.g., Dixon v. Ramsay, 7 U.S. (3 Cranch) 319 (1806); De Sobry v. De Laistre, 3 Am. Dec. 535 (Md. 1807) ; Atchison v. Lindsey, 43 Am. Dec. 153 (Ky. 1845) ; Heydock's Appeal, 7 N.H. 496 (1835) ; Matter of Grant-Suttie, 205 Misc. 640, 129 N.Y.S.2d 572 (Surr. Ct. 1954).

9 E.g., Rutledge v. Wiggington, 166 Ky. 421, 179 S.W. 389 (1915); Beaumont's Estate, 216 Pa. 350, 65 Atl. 799 (1907); Dupuy v. Wurtz, 53 N.Y. 556 (1873); Roberts' Succession, 2 Rob. 427 (La. 1842); Matter of Brown, 133 Misc. 457, 233 N.Y. Supp. 145 (Surr. Ct. 1929) (cases cited in 2 Beate, Confutct of Laws 1034 n.5).

10 See text at note 259 infra.

11 See notes $68,165,170,185,225,250,350,390,392$ infra; cf. notes 97, 99, 132, 138, 171-75, $187-89,267,270,278,337$ infra.

12 A case may be called an international conflicts case if it involves conflicts with the laws of another nation or country and interstate if it involves conflicts between the laws of the states of the United States. See Cheatraam, Goodrich, Grisword and Rease, Cases and Materials ox ConfLICTS of Laws 557 (3d ed. 1951).
} 
erty is governed by a variety of choice of law rules designed to give effect to the intention of the testator and to the domestic and conflicts policies of the forum.

In the following analysis of what is believed to be all the reported international cases in the United States involving issues of substantive law applicable in testamentary succession to personal property, an attempt will be made to outhine the historical and functional aspects of the domiciliary rule; to test its application in the light of the case law; and, placing the emphasis on the "actual doing" 13 of the courts rather than their language, to ascertain the rules actually governing formal and essential validity, interpretation, construction, and revocation of wills of movables and their policy bases.

HISTORICAL AND FUNCTIONAL ASPECTS OF THE "RULE"

\section{A. Area of Operation}

The Restatement of Conflict of Laws, following Professor Beale, ${ }^{14}$ and laying stress on the seemingly consistent language of several hundreds of judicial decisions, lays down the rule that "the validity and effect of a will of movables is determined by the law of the state in which the deceased died domiciled."15 This choice-of-law rule, apparently covering cases involving both interstate and international contacts, purports to be applicable by any forum in the distribution of personal property wherever situated, and solves all substantive issues of succession.

1. Very little indication of a conscious distinction between interstate and international contacts can be found in American judicial decisions ${ }^{\mathbf{1 6}}$ or legal literature. ${ }^{17}$ This distinction, however, finds support in a number of cases

13 See Llewellyn, On Reading and Using the Newer Jurisprudence, 40 CoLva. L. REv. 581, 608 (1940).

14 See 2 Beare, Conflict of Laws 1034, 1036 (1935); cf. Falconbrmge, Conftict of LAWs 275 n.(w) (1954).

15 Restateanent, Confict of Laws \$ 306 (1934).

10 See, e.g., Bank of Augusta v. Earle, 38 U.S. (13 Pet.) 517, 590 (U.S. 1839); D'Oench, Duhme \& Co. v. Federal Deposit Ins. Corp., 315 U.S. 447 (1942). The Restatement of the American Law Institute does not distinguish between the two fields, and presumably its rules are applicable to both interstate and international conflicts. But cf. FaICONBRIDGE, CoNELICT of Laws 231 (2d ed. 1947), arguing that "possibly we must think of the Restatement as an exposition of a system of conflicts of laws limited in its application to the states of the United States."

17 Modern writers stress the possibility, and perhaps, desirability of such distinction. See in general Du Bois, The Significance in Conflict of Laws of the Distinction between Interstate and International Transactions, 17 MINN. L. REv. 361 (1933); see also CHEATHAM, GoodricH, Griswold and Rease, Cases and Matertals on Conflict of Laws 662 (3d ed. 1951) ; Cook, The Logical and Legax Bases of the Conflict of Laws 223, 244 (2d ed. 1949); Ehrenzweig, Interstate and International Conficts Law: A Plea for Segregation, 41 MrN. L. REv. 717 
involving determination of inheritance rights ${ }^{\mathbf{1 8}}$ and seems justified by policy and other considerations. ${ }^{19}$ Apart from constitutional ties, the states of the Union, with the exception of Louisiana, share the heritage of common law doctrines and techniques; their domestic laws of inheritance are to a large extent uniform; methods of interpretation and legal thinking are similar and, perhaps most important, the economic and social environment, which according to modern sociological research plays a predominant role in the regulation of the descent of property upon death of the owner, ${ }^{20}$ is substantially the same. On the other hand, the expensive and painful establishment of the law of a foreign country by frequently conflicting expert testimony, the natural distrust as to its justice, and the fear of its mistaken application due to linguistic and other technical difficulties, are likely to induce the American judge to limit its apphicability as much as possible. Thus, constitutional links, psychological factors, and considerations of convenience of courts and parties are sufficient to predicate a distinct judicial attitude toward the inheritance laws of a foreign country.

(1957); Ehrenzweig, Recognition of Custody Decrees Rendered Abroad, 2 Ax. J. Coxr. L. 167, 171 (1953) ; Griswold, Renvoi Revisited, 51 HARv. L. REv. 1165, 1179 (1938) ; Neuner, Policy Considerations in the Conflict of Laws, 20 CAN. BAR REv. 479, 481 (1942); Rheinstein, Comparative Law and Conflict of Laws in Germany, 2 U. C\#. L. Rev. 232, 262 (1935); FaICONBridge, Confuict of Laws $269 \mathrm{ff}$. (1954).

18 See, e.g., In re New York Life Ins. and Trust Co., 139 N.Y. Supp. 695 (Surr. Ct.), aff'd, 209 N.Y. 585, 103 N.E. 315 (1913), for a conscious and articulate attempt at distinguishing, on policy grounds, between interstate and international conflicts. Surrogate Fowler said in the course of an elaborate opimion: "it would still be doubtful whether American decisions, on questions arising between citizens of different states of our own country, could justify the alteration of an established rule of international law.... In the state of New York, one of tho greatest commercial states of the world, we should be very cautious in the adoption of a general exception deviating from accepted rules of international dealing. In this matter the alleged divergence is between the law of Italy and the law of New York, not between the law of Massachusetts and the law of Maryland." 139 N.Y. Supp. at 703 (emphasis added). Distinction between interstate and international conflicts was also made in several cases involving acquisition by deceased of a domicile in a foreign country. E.g., Dupuy v. Wurtz, 53 N.Y. 556 (1873); Cruger v. Phelps, 21 Misc. 252, 47 N.Y. Supp. 61 (Sup. Ct. 1897) (France); Matter of Lachenmeyer, 144 Misc. 678, 258 N.Y. Supp. 641 (Surr. Ct. 1928) (Germany); Matter of Lynch, 170 Misc. 966, 11 N.Y.S.2d 303 (Surr. Ct. 1939) (Bahama Islands). See also Gibbs v. Chisholm, 204 Misc. 892, 126 N.Y.S.2d 150 (Sup. Ct. 1953) (distinction between executors appointed in a sister state and those appointed in a foreign country).

${ }^{19}$ See concurring opinion by Mr. Justice Jackson in D'Oench, Duhme \& Co. v. Federal Deposit Ins. Corp., 315 U.S. 447 (1942): "For example, the common law doctrines of conflict of laws worked out in a unitary systen to deal with conflicts between domestic and truly forcign law may not apply unmodified in conflicts between the laws of states within our federal system which are affected by the full faith and credit or other relevant clause of the Constitution."

${ }^{20}$ See in general MAX Weber, LAW IN ECONOMY AND SocIETY 137 (Rheinstein's transl. 1954); Nussbaum, Liberty of Testation, 23 A.B.A.J. 183 (1937); BOISSONADE, HistoIRE DE IA Reserve HérédTtatre ET De SEN Influence Morale ex Economique (1873); Touster, Testamentary Freedom and Social Control-After-born Children, 6 BUFFalo L. REv. 251 (1957),

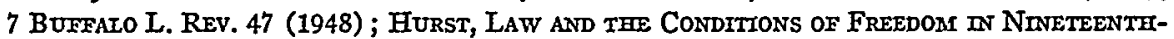
Century Untred States 8 ff (1956). 
A full study would be required to determine the rules governing testamentary succession to personal property in cases involving interstate contacts; ${ }^{21}$ the present article is confined to a survey of cases involving international contacts.

2. It is commonly stated that the law of the testator's domicile at death governs succession to personal property "wherever situated." This seems to imply that the domiciliary rule is actually applicable by courts sitting

21 The cases cited 2 BEAIE, CONFLICT OF LAWs 1034-36 (1935), do not seem to warrant the assertion that the law of the testator's domicile governs. Professor Beale in his discussion of "validity" and "effect" of wills of movables cites 41 decisions. Three of them are English cases: Enohin v. Wylie, 10 H.L. 1 (1862); In re Goods of Keiler, 61 L.J.P. (N.S.) 39 (1891); In re Cunnington, $1 \mathrm{Ch} .68$ (1924). In seventeen cases situs, fortm, and domicite were in the same jurisdiction: Rutledge v. Wiggington, 166 Ky. 421, 179 S.W. 389 (1915); Beaumont's Estate, 216 Pa. 350, 65 Atl. 799 (1907); Dupuy v. Wurtz, 53 N.Y. 556 (1873); Matter of Brown, 133 Misc. 457, 233 N.Y. Supp. 145 (Surr. Ct. 1929) ; Robert's Succession, 2 Rob. 427 (La. 1842); Cameron v. Watson, 40 Misc. 191 (1866) ; Matter of Anderson, 78 Misc. 713, 140 N.Y. Supp. 230 (Surr. Ct. 1912); Estate of O'Conner, 218 Cal. 518, 23 P.2d 1031 (1933); Slocomb v. Slocomb, 95 Mass. (13 All.) 38 (1866); Shute v. Sargent, 67 N.H. 305, 36 Atl. 282 (1892); Patterson v. Ranson, 55 Ind. 402 (1876); Manuel v. Manuel, 13 Ohio 458 (1862); Dickinson v. Belden, 268 III. 105, 108 N.E. 1011 (1915) (the case shows that part of the estate, situated in a nondomiciliary state, was distributed according to the latter's situs and forum law); Von Overbeck v. Dallgren, 28 F.2d 936 (6th Cir. 1928) ; McCume v. House, 8 Ohio 144 (1837); Nat v. Cooms, $10 \mathrm{Mo} .543$ (1847) "It does not appear upon what precise ground this decision was made, nor whether the will related to real or to personal estate." Moultrie v. Hunt, 23 N.Y. 394, 416 (1861); Matter of Van Kleeck, 95 Misc. 40, 158 N.Y. Supp. 539 (Surr. Ct. 1916). Four cases involve recognition of foreign probate decrees: Williams v. Saunders, 45 Tenn. (5 Cold.) *60 (1867) ; Freeman's Appeal, $68 \mathrm{~Pa} .151$ (1871) (suit by legatee against executor in ancillary administration to compel payment of legacy out of assets situated abroad); Jacobs v. Willis, 147 Tenn. 539, 249 S.W. 815 (1923) (domiciliary proceedings for the probate of a will mistakenly probated abroad); Trimble v. Dzieduzyiki, 57 How. Pr. 208 (N.Y. 1878). Five cases are clearly out of point: King v. Martin, 67 Ala. 177 (1880) (assumpsit for money had and received); Irwin's Appeal, 33 Conn. 128 (1865) (situs same as donicile and language favoring situs law); Davis v. Upson, 209 Ill. 206, 70 N.E. 602 (1904) (ordering new trial); In re Pretto, 4 Phila. 380 ( $\mathrm{Pa}$. Register's Ct. 1861) (denying probate for lack of "information" about the foreign domiciliary and actus law); Estate of Yuill, 109 Misc. 465, 178 N.Y. Supp. 871 (Surr. Ct. 1919) (involving issues of administration rather than substantive law of succession). One case involves succession to lands: Shaw v. Grimes, $187 \mathrm{Ky} .250,218 \mathrm{~S} . \mathrm{W} .447$ (1919). Another was subsequently reversed: Higgins v. Eaton, 188 Fed. 938 (N.D.N.Y. 1911), rev'd, 202 Fed. 75 (2d Cir. 1913). And while lip service was paid to the "general rule," situs lawe was applied over the contrary domiciliary law, Estate of Sloane, 171 Cal. 248, 152 Pac. 540 (1915) ; Johns Hopkins University v. Uhrig, $145 \mathrm{Md}$. 114, 125 Atl. 606 (1924); In re Chappell's Estate, 124 Wash. 128, 213 Pac. 684 (1923); Carey's Appeal, $75 \mathrm{~Pa} .201$ (1874); and the law of the testator's domicile at the time of execution in Ex parte McCornick, 2 Bradf. Surr. 169 (N.Y. 1852).

Thus, the domiciliary rule is actually supported by only five cases. Two involve formal validity: Desesbats v. Berquier, 2 Am. Dec. 448 ( $\mathrm{Pa}$. 1808); Grattan v. Appleton, 10 Fed. Cas. 992, No. 5707 (C.C. Mass. 1843) (application of situs and forum law, however, would lead to the same result; see infra text at note 66); and the remaining three construction, so that the preference for the law of the testator's domicile can be explained by the results reached in each case according to the testator's intention; Lowndes v. Cooch, 87 Md. 478, 39 Atl. 1045 (1898); Matter of Tallmadge, 109 Misc. 696, 181 N.Y. Supp. 336 (Surr. Ct. 1919) ; Matter of Coudert, 92 Misc. 109, 155 N.Y. Supp. 145 (Surr. Ct. 1915) (construction according to the situs law was "not desired and not pressed" by the interested parties). 
(1) at the domicile of the testator and adjudicating inheritance rights over personal property situated within the jurisdiction or abroad, (2) in a nondomiciliary state and adjudicating inheritance rights over property situated within the jurisdiction, and (3) in a state other than that of the situs or the testator's domicile and adjudicating right over personal property situated in a foreign jurisdiction.

The interest of the forum, however, in succession to local personal property or to property of local domiciliaries differs from that of a forum adjudicating inheritance rights over personal property situated abroad or belonging to foreign testators; these diverse interests may dictate the development of choice-of-law rules differing with the circumstances. ${ }^{22}$ Thus, it becomes important for the clarification of the pertinent problems of succession and the understanding of the policies underlying the choice-of-law rules to know the character of the forum facing the conflicts problem.

No international case has been found involving determination of inheritance rights by a court sitting in a domiciliary non-situs, ${ }^{23}$ or non-domiciliary and non-situs state ${ }^{24}$ consequently, no opinion can be expressed as to the law which is to be applied in these situations. This article is thus confined to the choice-of-law rules applied by American courts in the determi-

22 See Briggs, "Renvoi" in the Succession to Tangibles: A False Issue Based on Faulty Analysis, 64 YALE L.J. 195, 211 (1954); see also Rubin v. Irving Trust Co., 305 N.Y. 288, 299, 113 N.E.2d 424, 428 (1953): "The interest of the State in matters affecting the testamentary dispositions of its domiciliaries is much more than casual."

23 Considerations of convenience seem to account for the absence from the reports of cases involving proceedings in a domiciliary non-situs forum. Such a forum has normally both "local" and "international" jurisdiction to probate, construe, and determine the validity of a will of personal property situated abroad, but it lacks such jurisdiction, and ordinarily will abstain from entering a decree of distribution of property situated in another state or country. "Local" or "direct" jurisdiction is that "jurisdiction which a state, through its laws, assumes for its courts." Nussbaudr, Prtnctples of Prtvate Internationat Law 241 (1943). "International" or "indirect" jurisdiction, on the other hand, has been defined as "the power to decide a controversy in such a way that courts in other states and nations will 'generally' regard the judgment as conclusive". Hopkins, The Extraterritorial Effect of Probate Decrees, 53 YALE L.J. 221, 224, 263 (1944). See also Nussbaum, Jurisdiction and Foreign Judgments, 41 CouvM. L. Rev. 221, 224-225 (1941); of. Restatement, Confutct of Laws \$\$ 42, 470 (1934).

Whenever the estate is partly located at the domicile and partly abroad, the domiciliary court, according to the prevailing view, must be confined to the distribution of local assets. Ford v. Ford, 70 Wisc. 19, 33 N.W. 188 (1887); Lines v. Lines, 142 Pa. 149, 21 Atl. 809 (1891) ("this is familiar law"); Newcomb v. Newcomb, $108 \mathrm{Ky}, 582,57$ S.W. 2 (1900). If distribution of the entire estate is attempted, the enforceability of the decree at the situs of the personal property will depend entirely on forum law. See Hopkins, The Extraterritorial Effect of Probate Decrees, 53 YaIe L.J. 221, 225, 265 (1944); Lorenzen, Cases and Materuats on the CONFLICT OF Laws 15 (6th ed. 1951).

24 Similar considerations of convenience to those discussed in note 23 supra, along with the absence of "local" jurisdiction in most instances and the suspicion as to the enforceability of a decree obtained in a "naked" forum, seem to bave prevented the determination of inheritance rights in a forum which is neither that of the situs nor that of the domicile. 
nation of inheritance rights over personal property situated within the forum jurisdiction.

3. According to the Restatement, domiciliary law governs "the validity and effect of a will," including such "specific" issues as "the capacity to make a will, the form necessary to make a valid will, the validity of a particular provision in the will, the nature of the estate created, and the capacity of a legatee to take his legacy"; "25 "the right of a widow or child to take against the will";"26 and "revocation." $2 \pi$

The Restatement lacks systematic classification; indeed no such classification would be necessary were we to proceed on the assumption that the domiciliary law solves all substantive issues. ${ }^{28}$ But if, as here, the applicability of the rule is questioned, some scheme of rational classification might prove necessary to assist in the clarification of issues, and possibly, the differentiation of policies. It is submitted that the categories of formal and essential validity, construction, and revocation will prove most useful for this purpose. The analysis of the case law in accordance with this scheme will be proceeded by a short survey of the choice-of-law problem in its historical perspective and an outline of the procedural framework in which the choice-of-law rules operate.

\section{B. Historical Perspective}

\section{Continental Tradition}

The choice-of-law problem was first considered by those medieval continental writers to whom we refer as statutists. ${ }^{29}$ These writers, hiving in a world in which the law of the territorial sovereign was in conflict and frequently in competition with the "personal law" that each individual claimed to carry with him, were primarily concerned with the delimitation of the areas where each law was applicable and supreme. Having Roman law methods and doctrines as their common starting point and natural law ideas, maxims, and logical deductions therefrom, the statutists thought the solution of the conflicts problem to be the classification of all statutes as personal, real, and mixed.

Statutes having for their principal object the regulation of property

25 Restatentent, Conflict of Laws § 306 (1934).

20 Id. $\$ 301$.

27 Id. $\$ 307$.

28 This assumption probably explains the inadequate classification of the subject-matter in some of the leading texts. The distinction between formal and essential validity, revocation, and construction, becomes meaningless for the conflict of laws if all issues are referred to the

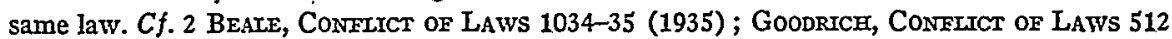
(1949 ed.); Cemesemre, Private Internationat Law 519 et seq. (1952); Dicey, Conflict of Laws 827 et seq. (1949); Stumirerg, Conflict of Laws 411 et seq. (1951). See Higgins v. Eaton, 202 Fed. 75 (2d Cir. 1913).

${ }^{29}$ See in general LanNé, Introduction aU Drort InTERnationat PrTvé 45 et seq. (1888). 
were classified as real; such statutes were considered supreme within the jurisdiction and applicable to all property controlled. ${ }^{30}$ Laws regulating principally the status of individuals were regarded as personal; and though potentially derived from a foreign source, were applicable within the jurisdiction to the determination of the status and the personal relations of a person. ${ }^{31}$ Finally, statutes regulating both the status of a person and property, or specific transactions, came to be classified as mixed; such statutes were applicable to all transactions taking place within the jurisdiction. ${ }^{32}$

While all statutists agreed that the laws referring to immovables were real and that transfer of title to such property was governed by the law of the situs, there was a difference of opinion with regard to the laws referring to inovables. D'Argentré, Burgundus, Bouhier, and Hertius, thought such laws to be personal. ${ }^{33}$ According to this view, movables had no situs but adhered to the person of the owner and were governed by his personal law, the law of his domicile. Radenbourgh, P. Voet, and Boullenois, regarded the laws referring to movables as real. ${ }^{34}$ Movables in their view had always a situs at the domicile of the owner and were governed by the law of that fictitious situs, the law of the owner's domicile. The difference of opinion, therefore, was merely nominal ${ }^{35}$ and the maxim mobilia sequuntur personam gives expression to the common statutist approach that all transfers of movables, whether inter vivos or causa mortis, are governed by the law of the owner's domicile. This maxim, however, was supplemented by the doctrine that with respect to formalities compliance with the law of the place of execution was sufficient to render the transaction valid everywhere. ${ }^{38}$

The statutists' solution to the conflicts problem, "full of intricacies, metaphysical niceties and overcurious learning" ${ }^{37}$ and based on fortuitous statutory language rather than on rational criteria, failed to cope with the exigencies of a growing international communication; along with the classification of the statutes, the domiciliary rule has long disappeared from most continental systems as either the law governing inter vivos transactions or

30 By "statutes" is meant the "whole municipal law from whatsoever source arising." Story, Confutct of Laws 11, 13 (1st ed. 1834). See also Livermore, Dissertations on the Contrartety of Postrtve Laws 22 (1823).

${ }^{31}$ See Story, Confutct of Laws 12 (1st ed. 1834).

32 Id. at 13.

33 Id. at $309-10$.

34 Id. at 310.

$35 \mathrm{Id}$. at 311 .

36 The maxim, originally expressing only an option, came later to be regarded as imperative and applicable to all transfers, regardless of the nature of the estate as movable or immovable. See Lorenzen, The Validity of Wills, Deeds and Contracts as Regards Form in the Confict of Laves, 20 Yate L.J. 427, 428, 431 (1911); 2 LAREE, INTRODUCTION AU DroIt INTERNatTonat PrLvé 397 (1888).

37 StORY, CONELTCT OF Laws 14 (1st ed. 1834). 
disposition of property upon death. ${ }^{38}$ But, at a time when the reform movement was about to begin, the statutist approach and the domiciliary rule were transplanted across the channel and spread roots in the English common law.

\section{English Precedents}

The choice-of-law rule that the law of the testator's domicile governs succession to personal property is not one of those rules "deeply embedded" in the common law. The rule represents a comparatively recent development; up to the end of the eighteenth century wills of Englishmen domiciled abroad were admissible to probate if executed in the English form ${ }^{39}$ and wills of foreigners disposing of personal property situated in England and executed "according to the custom of the country" were ordinarily given effect in accordance with English situs and forum law. ${ }^{40}$

The domiciliary rule was first applied in England during the middle eighteenth century in cases involving validity of inter vivos transfers of personal property, and particularly, discharge in bankruptcy. ${ }^{41}$ And, as typical of the common law process of reasoming from case to case, the rule was first extended to intestate and then to testamentary succession. Lord Hardwick's dictum in Pipon v. Pipon" that a "man's personal estate is supposed to follow his person, wherever he is, and is distributable accord-

38 See Nussbaud, Deutsches Internationales Privatrecht 303 (1932) ; Niboyet, Droit Internationad Privé 598 et seq. (1946) ; Ehrenzweig-Fragistar-Yiannopoulos, AJiericanGreek Private International Law 74 ff. (1957).

${ }^{39}$ See, e.g., Duchess of Kingston's Will (1791), cited in 2 Add. Ecc. 21; Curling v. Thornton, 2 Add. Ecc. 6 (1823). See also Lorenzen, The Validity of Wills, Deeds and Contracts as Regards Form in the Conflict of Laws, 20 YaLE L.J. 427, 434 (1911).

40 See Bowaman v. Reeve, 24 Eng. Rep. 259 (1721). Testator died domiciled in his native Holland, having executed a will "according to the custoin of the country." Upon his death, creditors seized the estate in Holland. The executor and residuary legatee did not "intermeddle therewith," but proved instead the will in England and took possession of all property there, personal and real. In a suit by unsatisfied specific devisees from Holland "to have a recompense" to the value of their devises, the Lord Chancellor, without specifying the applicable law, decreed account and satisfaction. "The residuum is chargeable with the debts," he declared. See also Tourton v. Flower, 3 P. Wm. 369 (1735), involving inconsistent probate decrees under French (domiciliary) and English (situs and forum) law.

41 See case discussed in BeAwe's Lex MERoatoria 516 (6th ed. 1723). The same rule was apphed in Captain Wilson's Bankruptcy, stated by Lord Loughborough in Sill v. Worswick, 1 H.Bl. 665, 692 (1791), citing Solomons v. Ross, 1 H.BI. 131 (1764); Jollet v. Deponthieu, 1 H.B1. 132 (1769); Grattan v. Cottingham, 1 H.BI. 132 (1764). See also Hunter v. Potts, 4 T.R. 182 (1791); Sills v. Worswick, 1 H.Bl. 665 (1791), laying down for the first time the general principles governing transfers of movables. See also LTVERMore, Dissertations on tar CONTRARIETY OF Posimve Laws 141 (1823).

$42 \mathrm{Amb} .25$ (1744). Neither were reasons given, nor authority cited for this proposition. The counsel's argument, however, runs as follows: "If the effects were to be distributed according to their locality, it would greatly affect our public funds; for no foreigner would be concerned in thein if, after his death intestate, the personal estate which he had here was to be distributed according to our laws, and not according to those of his country." 
ing to the law of the country where his person is" was cited with approval in Thorne v. Watkins ${ }^{43}$ and Burn v. Cole $;^{44}$ all three cases involved administration. Relying on those precedents, Lord Thurlow applied domiciliary law in the succession of an intestate English citizen in Bruce v. Bruce; ${ }^{45}$ and by a series of decisions ${ }^{46}$ the rule that the personal estate of an intestate is to be distributed according to the law of his domicile became firmly established. Finally, the rule was extended to testamentary succession, and it became settled in 1830 , by the decision of the Court of Delegates in Stanley v. Barnes ${ }^{47}$ that the validity of a will of personal property was governed by the law of the testator's domicile at death.

"Comity" considerations, and the idea that they were adopting a rule of "jus gentium" may have influenced the English judges in their recognition of the domiciliary rule; for, although the cases do not expressly refer to the writings of the statutists, it is not a mere coincidence that they fall in line with the doctrines then prevailing on the continent. ${ }^{48} \mathrm{But}$ the preference for the law of domicile can be also explained by its beneficial impact on British financial interests ${ }^{49}$ and the fact that in the vast majority of cases the rule lead to the application of English law as the law of the domicile of origin. Thus, if the testator was an Englishman with a domicile of origin in

432 Ves. Sen. 35 (Ch. 1750).

44 Amb. 414 (P.C. 1762).

456 Bro.P.C. 566 (H.L. 1790).

46 Balfour v. Scott, 6 Bro.P.C. 550 (H.I. 1793); Bempde v. Johnston, 3 Ves.Jr. 198 (Ch. 1796); Ommaney v. Bingham, cited 5 Ves.Jr. 757 (H.L. 1796); Sommerville v. Lord Sommerville, 5 Ves.Jr. 750 (Ch. 1801).

47 Stanley v. Bernes, 3 Hagg.Ecc. 373 (1830). See also Craigie v. Lewin, 3 Curt.Ecc. 435 (1842); De Zichy Ferraris v. Hertford, 3 Curt.Ecc. 468 (1843); Bremer v. Freeman, 10 Moo. P.C. 306 (1857). Cf. Curling v. Thornton, 2 Add.Ecc. 6 (1823), admitting to probate under the English situs law a will invalid under French domiciliary law.

48 Professor Nussbaum, Deutsches Internationazes Privatrecht 23, 302 n. 1 (1932), suggests that the doctrines of the Dutch School were transplanted, through Scotland, to England and the United States. This could, perhaps, explain the prevalence of the "comity" doctrine as the basis of all law of the conflict of laws, in the English and American legal systems, but it does not satisfactorily explain the adoption of the domiciliary rule. Scottish law favored the lex rei sitae principle, and it was only through a series of decisions of the House of Lords that the domiciliary rule became a part of the law of Scotland. See Bruce v. Bruce, 6 Bro.P.C. 566 (H.L. 1790), where Scottish authorities applying situs law were collected. Lord Thurlow observed in that case that "to say that the rei sitae is to govern though the domicilium of the deceased be without contradiction in a different country, is a gross misapplication of the rules of civil law and jus gentium, though the law of Scotland on this point is constantly asserted to be founded on them." Cf. Parra, DIE Reger "Locus Regit ActuM" und DIE Formien der TESTAMENTE 110 (1955).

49 See Ogden v. Saunders, 25 U.S. (12 Wheat.) 213, 1827). Justice Johnson suggested that "It was all important to a great commercial nation, the creditors of all the rest of the world, to maintain the doctrine as one of universal application." See also Blake v. Williams, 23 Mass. (6 Pick.) *286 (1828). "The English courts have gone upon this principle; as they give credit to all nations and owe none, the rule of comity, in this case, is for their advantage." (Id. at 291). 
England, English law would apply regardless of an extended residence in the colonies..$^{50}$

The possible hardship involved in the exclusive reference of succession to the testator's domiciliary law was not felt in England until the will of an English woman, executed in the English form in Paris, was denied effect in France as having failed to comply with the law of the place of execution, and in England as having failed to comply with the law of the domicile at death. ${ }^{52}$ Shortly following the decision in that case, Lord Kingsdown secured the passage of an act introducing hiberal rules with respect to the law governing succession, ${ }^{62}$ but by that time the domiciliary rule had already crossed the Atlantic and had started its career in the American common law.

\section{Early American Precedents}

In the United States, in contrast to England, the domiciliary rule was denounced by the courts in bankruptcy proceedings, ${ }^{53}$ and was never consistently applied in other inter vivos transfers of personal property. Though strongly advocated by Livermore ${ }^{54}$ who first wrote on the subject and by Judge Story, ${ }^{65}$ in these situations the rule met the reluctance of the courts and the criticism of other commentators ${ }^{56}$ and is completely abandoned today. ${ }^{87}$

But with respect to the disposition of personal property upon death, the domiciliary rule-taken over from the English precedents of the late eigliteenth century as a rule of public international law ${ }^{58}$ - still survives in

50 See Bruce v. Bruce, 6 Bro.P.C. 566 (H.L. 1790); Munroe v. Douglas, 5 Madd. 379 (1820) ("A domicile in India is, in legal effect, a domicile in the province of Canterbury and the law of England . . . is therefore to be applied to his personal property.").

51 Bremer v. Freeman, 10 Moo.P.C. 306 (1857).

52 See Phmimore, IV InTERnaTronar LAW 226 (1889); Lorenzen, The Validity of Wills, Deeds and Contracts as Regards Form in the Confict of Laws 20 YaIE L.J. 427, 435 (1911).

53 As early as the colonial era the American courts denounced the domiciliary rule in bankruptcy cases and "Lord Turlow heard with surprise, in 1787, that some of the states in America did not respect the title of the assignees under an English commission." Lrverurore, Dissertatjons on tere Contrariety of Positive Laws 151 (1823). See also Harrison v. Sterry, 9 U.S. (5 Cranch) 289 (1809); Ogden v. Saunders, 25 U.S. (12 Wheat.) 213 (1827).

54 Livermore, Dissertations on the Contrartety of Posttive Laws 133, 136 (1823).

55 Story, Confutct of Laws 312, 395 (1st ed. 1834).

${ }^{58}$ See Lees v. Harding, 68 N.J. Eq. 622,60 Atl. 352 (1905) ("That personal property has no situs seems rather a metaphysical position than a practical and legal truth."); Ames Iron Works v. Warren, 76 Ind. 512 (1881); Hutchison v. Ross, 262 N.Y. 381, 187 N.E. 65 (1933) ("The maxim mobilia sequuntur personanı cannot always be carried to its logical conclusion. Practical considerations often stand in the way."). See also 2 BeaIE, ConfLICT of LAwS 978 (1935) ; Goodrich, Confuict of Laws 470 (1949 ed.).

57 See RESTATENENT, ConfLICT OF LAwS $\$ \S 334,256$ (1934).

58 See, e.g., Desesbats v. Berquier, 2 Am. Dec. 448 (Pa. 1808); In re New York Life Ins. and Trust Co., 139 N.Y. Supp. 695, 703 (Surr. Ct. 1913); Parsons v. Lyman, 20 N.Y. 103 (1859); Higgins v. Eaton, 202 Fed. 75 (2d Cir. 1913); Sneed v. Ewing, 22 Am. Dec. 41 (Ky. 1831); Atchison v. Lindsey, 43 Am. Dec. 153 (Ky. 1845); Heydock's Appeal, 7 N.H. 496 (1835). 
the language of judicial decisions and is to be found as a fundamental precept in the Restatement of Conflict of Laws.

The earliest reported case in this country applying the law of the testator's domicile at death was Desesbats v. Berquier. ${ }^{50}$ Deceased, a French citizen, executed in the island of San Domingo where he was domiciled an instrument designed to dispose of personal property situated in Pennsylvania. This instrument, admittedly "not a last will and testament" under the law of the place of execution and the domicile of the testator, was offered for probate in Pennsylvania where it was a valid will under the domestic law of that commonwealth.

The issue whether such an instrument should be given effect under the law of the situs or denied effect according to the law of the domicile was novel for the Pennsylvania court; the precedents were scarce "with no authority directly in point," and decision could be given either way. Discussing English precedents, the court considered as "very commendable" the rule that "succession to the personal estate of an intestate is to be regulated according to the law of the country of which he was a [domiciled] inhabitant at the time of his death." "The presumed intention of the deceased," the court said, "the presumption that everybody is expected to know the law of his country," and "the desire of the civilized nations to permit the law of the domicile to prevail," suggested the applicability of the domiciliary rule. Thus, laying emphasis on policy considerations and lamenting the result in the particular case before it, ${ }^{80}$ the court denied probate to the instrument. But the Desesbats case, though often cited, was never actually followed even as to its narrow holding that a will invalid under both the law of the testator's domicile at death and the law of the place of execution should be denied effect in spite of the favorable law of the situs.

502 Am. Dec. 448 (Pa. 1808), cited in STORY, CONFIICT OF Laws 394 (Ist ed. 1834). LIVERmore, Dissertations on the Contrariety of Positive Laws 130 (1823), and 2 Beare, Conflict of Laws 1030, 1041 (1935), 'citing two earlier decisions; Dixon v. Ramsay, 7 U.S. (3 Cranch) 319 (1806), and De Sobry v. De Laistre, 3 Am. Dec. 535 (Md. 1807). Neither involved substantive issues of succession. The issue in the Dixon case was "whether plaintiffs (foreign executors) can maintain an action in the District of Columbia, without taking letters testamentary in the District of Columbia"; and in the De Sobry case, whether an executor c.t.a. is "answerable to the crectitors."

60 "But they contend that the establishment of the will . . . will carry the wishes of the foreigner into effect. It is very true that in this instance it will; but we must take care how we establish a principle, which, at the same time it carries the will of one man into effect, may tend to destroy the will of one hundred others ... This [apphication of local law] may produce very mischievous consequences, not only to foreigners who have property here, but to our own citizens who may bave property abroad. For we must expect that other nations will pay no greater regard to us than we pay to them. We are a commercial people, and should be forward in reciprocating those acts of courtesy which the nations of Europe are in the habit of practicing" (at 450). 
In Harvey v. Richards, ${ }^{\text {,1 }}$ chronologically the first case citing Desesbats v. Berquier, the court did not actually choose between foreign and domestic law. An American citizen died domiciled in Calcutta leaving a will and personal property in Massachusetts. In a proceeding initiated in Massachusetts by American next-of-kin for the distribution of the residue of the estate as to which admittedly the deceased had died intestate, the power of the court to decree distribution locally was challenged by the administrator. The court held, in an opinion by Story, J., that it was within its discretion to enter a decree of distribution of local personal property, and that "the distribution whether made here or abroad, must be according to the law of the testator's domicile." "But," the court continued, "the law of Calcutta ... is the law of England; and as that is the same as the law of Massachusetts, the distribution would be the same, as if the testator had died domiciled here"; a decree of distribution was entered according to the law of Massachusetts.

In the following decades, wills invalid under the law of the testator's domicile at death were carried into effect by a reference to the law of the place of execution in one case, ${ }^{62}$ and to the law of the domicile at the time of execution in another. ${ }^{63}$ And in three cases ${ }^{64}$ the domiciliary law at death was disregarded and foreign executed wills conforming with the law of the place of execution and that of the domicile at the time of execution were held to constitute a valid testamentary disposition of personal property. ${ }^{65}$

The only case in which effect was denied to a foreign executed will of movables on the authority of Desesbats v. Berquier was Grattan v. Appleton $^{68}$ Deceased in that case died domiciled in New Brunswick, Canada, and his alleged will was denied effect in Massachusetts, the situs of personal property, on the ground that the instrument was invalid under the law of the testator's domicile. But it appears from the statement of facts that the instrument was also invalid under the law of the place of execution and that of the situs. And, as the court observed, even if the instrument were a valid will its probate would serve no purpose since deceased was insolvent.

The domiciliary rule first became settled in this country in 1861 by the celebrated decision of the New York Court of Appeals in Moultrie $v$. Hunt, ${ }^{87}$ a case involving interstate conflicts. Colonel Hunt changed his

611 Mason 381 (1818).

62 Schultz v. Dambmann, 3 Bradf.Sur. 379 (N.Y. 1855); cf. text at note 90 infra.

${ }^{63}$ Ex parte McCormick, 2 Bradf.Sur. 169 (N.Y.1852); cf. text at note 89 infra.

64 Matter of Roberts' Will, 8 Paige 446 (N.Y. Ch. 1840); Matter of Roberts' Will and Codicil, 8 Paige 519 (N.Y.Ch. 1840); McCune v. House, 8 Ohio 144 (1837).

65 For other early American decisions bearing on the problem of applicable law see Nat. v. Coons, supra note 12 ; Harrison v. Nixon, infra note 351. Cf. Parsons v. Lyman, infra note 68. 6810 Fed. Cas. 992, No. 5707 (C.C.Mass. 1843).

B7 23 N.Y. 394 (1861). 
domicile early in 1854 from South Carolina to the city of New York and died there in the fall of the same year. A will executed in South Carolina while the testator was domiciled in that state was offered for probate in New York. The instrument was a good and valid will under the law of South Carolina but null and void under the law of New York, the testator's domicile at death and situs of the personal property. The Surrogate admitted the will to probate, writing an elaborate opinion and the Supreme Court affirmed. But on appeal the Court of Appeals reversed, three justices vigorously dissenting. The majority, relying on principle rather than authority ${ }^{68}$ and on Story's questionable interpretation of continental sources, ${ }^{8}$ held that the will thougl formally executed according to the law of the testator's domicile at the time of execution (and also to the law of the place of execution), should be denied probate and effect as it failed to conform with the law of New York, the testator's domicile at deathand the situs of the personal property.

The conclusion from this short historical survey of American precedent is that, in spite of contrary language, the domiciliary rule could not be regarded as settled in the field of international conflicts as recently as the

68 The majority relied on Desesbats v. Berquier, supra note 62; Grattan v. Appleton, sutpra note 66; Nat v. Coons, subpra note 12; Parsons v. Lyman, 20 N.Y. 103 (1859) (involving ancillary proceedings for the recognition of a foreign probate). All those cases were distinguished by the Surrogate and the dissenting Justices of the Court of Appeals; and the majority was compelled to admit that "none of those decisions presented the case of a change of domicile after the signing and attesting the will." Moreover, "in absence of contrary authoritative ruling on the precise point involved" and relying on Matter of Roberts' Will, 8 Paige 446 (N.Y. Ch. 1840), and Matter of Roberts' Will and Codicil, 8 Paige 519 (N.Y.Ch. 1840), the Surrogate had declared that "the rule locus regit actum has been generally received" and adnitted the will to probate. Hunt v. Moultrie, 3 Bradf.Sur. 322 (N.Y. 1855).

${ }^{69}$ See Story, Confzict of Laws 398 (1st ed. 1834). "But it may be asked, what will be the effect of a change of domicile after a will is made of personal property, if it is valid by the law of the place, where the party was domiciled, when it was made, and not valid by the law of the domicile at the time of death? The terms, in which the general rule is laid down, sufficiently establish the principle, that in such a case the will is void, for it is the law of the actual domicile, which must govern." The Surrogate (at 340) and the dissenting opinion of the Court of Appeals (at 410) pointed out that Story's text is not sustained by his authorities. Story quoted from JoEn VoET, at PaNd. Lib. 3, Tom. 2, No. 13. The passage related only to the question of testamentary capacity and not to formalities. The example Voet gives is this: if one is hiving in Holland, where one may validly execute a will at the age of fifteen, makes his will and then changes his domicile to Utrecht, where in the case of a male testator the eighteenth year is required for the valid execution of a will-his will of novables would be rendered void by the change of domicile. Voet also observes that the same thing would occur if one should institute his wife heir in a country where that was lawful, and then changes his domicile to a place where it was not lawful. It should be noticed that JOEN VoET, DE STATUTIS, Lib. 1 No. 13, 14,15 , is one of the strongest supporters of the doctrine locus regit actum along with almost all continental writers of the period. See LarNé, Introduction aU Droit Internatronar PrivE, 328-428 (1888); Lorenzen, The Validity of Wills, Deeds and Contracts as Regards Form in the Confict of Laws, 20 YaLE L.J. 427,429 (1911). 
middle of the past century. Whether that rule became the law following the decision in Moultrie v. Hunt-generally regarded as establishing the applicability of the domiciliary law in the interstate conflicts situationremains to be seen from the following analysis of case law.

\section{Procedural Framework}

"Procedural regulations enter into and condition all substantive law's becoming actual." 70 This applies fully to cases of succession involving contacts with some foreign country and, therefore, a description of the procedural framework of succession seems highly desirable.

In general, at common law personal property does not descend to the heir or legatee directly as it does in most civil law countries but title is vested in him by the decree of distribution, ${ }^{71}$ preceded by the probate of the will and the administration of the estate. The distinction between administration and distribution, though it cannot be always clearly drawn, is particularly important in the law of conflicts because administration, as a matter of procedure, is governed by the law of the forum while distribution, as a matter of substance, is subject to the law governing succession. ${ }^{73}$

A will of personal property in order to pass title must be probated in the jurisdiction in which such property is situated. ${ }^{33}$ Statutory provisions now in effect in almost all states regulate in detail the requirements for the probate of foreign wills and define the instruments which may be admitted to probate on the basis of authenticated copies of foreign proceedings, and those - usually resident's wills - that must be presented for original probate. $^{74}$

T0 LIETELIYN, The BraMLBLe BusH 17 (1951).

71 See Arknsson, WIIIS 796 (1953). Probate and administration may not be necessary when title vests in the distributee under the domiciliary law of a civil law country. Ullmann v. Ullmann, 223 App. Div. 636, 229 N.Y. Supp. 176 (1st Dep't 1928) (Germany); Roques v. Grosjean, 66 N.Y.S.2d 348 (Sup. Ct. 1946) (France) ; Anglo-California Nat. Bank v. Lazard, 106 F.2d 693 (9th Cir. 1939) (France); Berney v. Drexel, 33 Hun 34 (N.Y. 1884) (France); Du Roure v. Alvord, 120 F. Supp. 166 (S.D.N.Y. 1954) (France). But cf. Matter of Nordhauser, 197 Misc. 119, 94 N.Y.S.2d 48 (Surr. Ct. 1950) (Germany); Emmerich v. May, 130 F. Supp. 426 (S.D.N.Y. 1955) (Holland); In re Prevost's Estate, 138 N.Y.S.2d 828 (Surr. 1955) (France).

72 Emmerich v. May, 130 F. Supp. 426 (S.D.N.Y. 1955) (Holland). See also BrESLAUER, PrTVATE InTERNATtoNat LAW OF SUCCESSTON 4 (1937).

73 Armstrong v. Lear, 25 U.S. (12 Wheat.) 169 (1827).

74 See in general Hopkins, The Extraterritorial Effect of Probate Decrees, 53 YALE L.J. 221, 254 ff. (1944). In principle original probate must be held in the domiciliary state. In re Lockwood's Will, 147 N.Y.S.2d 106 (Surr. 1955) (Norway); Matter of Patenotre, 206 Misc. 231, 134 N.Y.S.2d 402 (Surr. 1954) (France); In re Smith's Estate, 126 Mont. 558, 255 P.2d 687 (1953) (interstate). However, wills of non-residents may also be originally probated at the situs of the personal property pursuant to the provisions of a statute or according to the directions of the deceased. Darrow v. Fifth Third Union Trust Co., 139 N.E.2d 112 (Com. PI. Ohio 1954); Estate of Wood, 155 N.Y.S.2d 959 (Surr. 1956); Matter of Holden, 110 Vt. 60, 1 A.2d 721 (1938) ; Bolton v. Barnett, 131 Miss. 802, 95 So. 721 (1923) (interstate cases). While several 
Proceedings at the situs of the personal property, and the resulting administration, are designated as ancillary when a will has been originally probated in some other jurisdiction-ordinarily that of the testator's domicile at death-and applieation is made for probate on the basis of a duly authenticated copy of the foreign proceedings. ${ }^{75}$

Sister-state proceedings and probate decrees though not generally entitled to full faith and credit under the Constitution ${ }^{78}$ are, according to the prevailing view, enforceable at the situs of the personal property and conclusive as to all issues adjudicated if the foreign court had jurisdiction of the subject-matter and all interested parties were properly before it. ${ }^{7 \pi}$ Recognition of probate decrees rendered in a foreign country rather than in a sister state may present a more difficult case, particularly where the foreign decree does not satisfy domestic standards of justice. In such a case it may be suggested that the court at the situs lacks jurisdiction to probate the authenticated copies, ${ }^{78}$ that the foreign will has not been sufficiently established or probated abroad, ${ }^{79}$ that the foreign court was without

states require for original proceedings that the will be executed in writing and subscribed by the testator, no such requirement exists with respect to ancillary proceedings. In re Batsholt's Estate, 66 N.Y.S.2d 358 (Surr. Ct. 1946) (nuncupative will of American citizen executed in Switzerland where testator was domiciled). Forum law determines the persons entitled to ancillary letters of administration. Matter of Renard, 157 Misc. 174, 283 N.Y. Supp. 44 (Surr. Ct. 1935) (France); In re Patenotre's Estate, 123 N.Y.S.2d 492 (Surr. Ct. 1953) (France); Matter of Zietz, 201 Misc. 580, 105 N.Y.S.2d 876 (Surr. Ct. 1951) (Lichtenstein); Matter of Kassam, 141 Misc. 366, 252 N.Y. Supp. 706 (Surr. Ct. 1931) (Estonna); Matter of Mayer, 84 Misc. 9, 145 N.Y. Supp. 665 (Surr. Ct. 1914) (France) ; cf. Sultan of Turkey v. Tiryakian, 147 N.Y. Supp. 978 (Sup. Ct. 1914) (Turkey). The forum may dispense with requirements such as "envol en possession" imposed on the executors by the domiciliary law. In re Daltroff's Estate, 43 N.Y. S.2d 75 (Surr. Ct. 1943) (France); Matter of Spitzer, 170 Misc. 160, 9 N.Y.S.2d 868 (Surr. 1939) (France); In re Bloch's Estate, 48 N.Y.S.2d 823 (Surr. Ct. 1944) (France); In re d'Ursel's Estate, 74 N.Y.S.2d 558 (Surr. Ct. 1947) (France); In re Blumenthal's Estate, 90 N.Y.S.2d 540 (Surr. Ct. 1949) (Holland).

75 See Matter of Schrader, 196 Misc. 400, 92 N.Y.S.2d 160 (Surr. 1949) (Germany); Matter of Patenotre, 206 Misc. 231, 134 N.Y.S.2d 402 (Surr. 1954) (France).

76 See, e.g., Matter of Beban, 135 Misc. 25, 237 N.Y. Supp. 701 (Surr. Ct. 1929); Matter of Nordhauser, 197 Misc. 119, 94 N.Y.S.2d 48 (Surr. Ct. 1950); Matter of Roeben, 171 Misc. 548, 13 N.Y.S.2d 53 (Surr. 1939); affd, 285 N.Y. 807, 35 N.E.2d 195 (1941); Brown v. Fletcher's Estate, 210 U.S. 82 (1908) ; cf. Williams v. Saunders, 45 Tenn. (5 Cold.) *60 (1867); Kurtz v. Kurtz' Estate, 182 Atl. 456 (Md. Ct. of App. 1936). See generally Hopkins, The Extraterritorial Effect of Probate Decrees, 53 YALE L.J. 221 (1944).

77 Ordinarily, wills of non-residents properly probated at their domicile may not be subject to collateral attack at the seat of ancillary admimistration. See Jones v. Jones, 301 S.W.2d 310 (Tex. Civ. App. 1957) (interstate). However, the adjudication of domicile abroad does not bind the situs courts. See In re Lockwood's Will, 147 N.Y.S.2d 106 (Surr. 1955) (Norway).

78 See Matter of Armstrong, 167 Misc. 592, 4 N.Y.S.2d 413 (Surr. Ct. 1938) (Ireland); Matter of Zietz, 201 Misc. 580, 105 N.Y.S.2d 876 (Surr. Ct. 1951) (Lichtenstein).

79 See Matter of Morland, 184 Misc. 435, 55 N.Y.S.2d 910 (Surr. Ct. 1944) ("The documents submitted by the petitioner here are entirely inadequate as a proof of the establishment or probate of the will in Norway"); Matter of Connell, 221 N.Y. 190, 116 N.E. 986 (1917) (Canada); In re Neukircher's Estate, 48 N.Y.S.2d 868 (Surr. Ct. 1944) (Holland) ; Laches may preclude ancillary proceedings for the probate of wills established abroad. Matter of Hug, 201 Misc. 709, 107 N.Y.S.2d 664 (Surr. Ct. 1949) (Switzerland). 
jurisdiction, ${ }^{80}$ or even that the death of the testator has not been satisfactorily proved. ${ }^{81}$

The admissibility of a will to probate on the basis of authenticated copies of a foreign proceeding does not involve a choice-of-law problem but one of effect and recognition of a foreign judgment; ${ }^{82}$ and although some courts deal with this problem in terms of choice-of-law, their decisions, notwithstanding much of their language, are outside the scope of the present study.

Where the situs and forum law denies conclusive effect to foreign probate proceedings, or where there was no previous probate abroad, the will is offered at the situs of the personal property for original probate and the resulting administration is ordinarily designated as principal. In such a case, if the will involves substantial foreign contacts the situs courts are faced with a choice-of-law problem.

In probate proceedings the courts at the situs are confronted only with the issues of formal validity of the will-i.e., its compliance with the forms prescribed for the valid execution of testamentary instruments-and the capacity of the testator. ${ }^{83}$ The grant of probate establishes within the jurisdiction the fact that the instrument is the will of a competent testator, formally executed. However, it is not conclusive as to whether the instrument is essentially valid, for it is not the busmess of the probate court to determine the effect of the will in proceedings to probate; even a totally ineffective will is admissible to probate if it is formally executed by a testator with testamentary capacity. ${ }^{84}$

${ }^{80}$ See Opton v. Guaranty Trust Co., 194 Misc. 261, 86 N.Y.S.2d 720 (Sup. Ct. 1949) (Holland) ; In re Neukircher's Estate, 48 N.Y.S.2d 868 (Surr. Ct. 1944) (Holland).

81 See Opton v. Guaranty Trust Co., 194 Misc. 261, 86 N.Y.S.2d 720 (Sup. Ct. 1949) (Holland); Matter of Goldstein, 299 N.Y. 43, 85 N.E.2d 425 (1949) (Holland). Cf. In re Elias' Estate, 70 N.Y.S.2d 856 (Surr. Ct. 1947) (France); In re Kohn's Estate, 124 N.Y.S.2d 861 (Surr. Ct. 1953) (Czechoslovakia).

82 See, e.g., the following cases involving ancillary probate on the basis of authenticated copies: In re de Von der Hallen's Trust, 169 N.Y.S.2d 698 (Special Term 1957) (Argentina); In re Batsholt's Estate, 66 N.Y.S.2d 358 (Surr. Ct. 1946) (Switzerland); Matter of Renard, 157 Misc. 174, 283 N.Y. Supp. 44 (Surr. Ct. 1935) (France); Matter of Warburg, 129 Misc. 832, 223 N.Y. Supp. 780 (Surr. Ct. 1927) (Germany); Goldtree v. McAlister, 86 Cal 93, 23 Pac. 207 (1890) (England); In re Connell's Will, 188 App. Div. 772, 177 N.Y. Supp. 414 (1st Dep't 1919) (Canada); Matter of Marsland, 142 Misc. 230, 254 N.Y. Supp. 293 (Surr. Ct. 1931) (Switzerland); Matter of Betancourt, 144 Misc. 173, 258 N.Y. Supp. 649 (Surr. Ct. 1931) (Cuba); Mather v. Cunningham, 105 Me. 326, 74 Atl. 809 (1909) (China); In re Coppock's Estate, 72 Mont. 431, 234 Pac. 258 (1925) (China); Drohan v. Avellar, 276 Mass. 441, 177 N.E. 583 (1931) (Portugal); Ennis v. Smith, 55 U.S. (14 How.) 400 (1852) (SwitzerlandFrance).

83 See Rabe v. McAlister, 177 Md. 97, 8 A.2d 922 (1939) (Germany); Matter of Rubens, 128 App. Div. 626, 112 N.X. Supp. 941 (1st Dep’t 1908) (France). See also ArkINson, Wrirs 499, 518 (1953).

84 "A will may be entitled to probate, although all its dispositions of property may be discovered to be invalid." Matter of McMulkin, 5 Dem. 295 (N.Y. Surr. 1886), cited with approval by Matter of Rubens, 128 App. Div. 626, 629, 112 N.Y. Supp. 941, 944 (1st Dep't 1908). 
The final step in the process of succession is a decree of distribution entered by the situs court. ${ }^{85}$ When the issues of formal validity and testamentary capacity have been favorably decided in the probate proceedings, the court is faced with what we may call the issue of essential validity of the disposition and with determination of the testator's intention.

Where the proceedings at the situs are original and the administration principal, a decree of distribution will be locally entered. But where the administration is merely ancillary, the court has two alternatives; it may (1) direct the personal representative to remit the assets to the domiciliary court or (2) enter a decree of distribution locally as if it were the seat of principal administration. According to the Restatement, it should be normally expected that the assets will be remitted to the domiciliary court for distribution; ${ }^{86}$ but data showing the frequency of this practice are not available. Regardless of the nature of the administration as principal or ancillary, all the cases herein involve decrees of distribution entered at the situs of the personal property.

\section{II}

PRINCIPLES DEDUCIBLE FROM CASE LAW

\section{A. Formal Validity}

It is traditionally stated that the formal validity of wills of movables is governed by the law of the testator's domicile at death. ${ }^{87}$ Accordingly, a will executed and formally valid under that law is ordinarily admitted to probate at the common law situs of the personal property irrespective of compliance with domestic standards.

But analysis of the cases also shows that wills invalid under the domiciliary law of the testator are quite ordinarily admitted to probate in com-

85 See Atrmsson, Writs 796 (1953); Goodrich, Conflict of Laws 576 (1949 ed.).

86 Restatexent, Confutct of Laws $\$ 522$, comment $b$ (1934). See Note, 35 Am. Dec. 488 (1882).

87 Restatearent, Confuict of Laws $\$ 306$, comment $b$ (1934). See also 2 Beare, Conftict of Laws 1035 (1935); Goodrich, Conflict of Laws 514 (1949 ed.); Bresiauer, Prtvate International Law of Succession 108 (1937); Cheshire, Private Internationat Law 522 (1952) ; 4 PaIGe, WIIIS 705 (1941) ; Wharton, Conflict of LaWs 1303 (1st ed. 1872) ; StorY, Confurcr of Laws 394 (1st ed. 1834); Note, 169 A.L.R. 554 (1947) ; Lorenzen, The Validity of Wills, Deeds and Contracts as Regards Form in the Conflict of Laws, 20 Yare L.J. 427 (1911); Rebel, The Form of Wills, 6 VAND. L. REv. 533 (1953). Distinction, however, is commonly made with respect to the formal validity of wills exercising a power of appointment. See 2 BEALE, CONFuict of Laws 1010 (1935); GoODRICH, CONFLICT OF Laws 531 (1949 ed.); BrEsLaUER, Private International Law of Succession 183 (1937) ; Fatconbrigge, Conftict of Laws 531 (1954); Mulford, The Conflict of Interest in Powers of Appointment, 8 U. PA. I. REv. 403 (1939); Durand, Exercise of Power of Appointment, 95 Trusts \& EsTates 424 (1956). Cf. In re N.X. Life Ins. and Trust Co., 139 N.Y. Supp. 695 (Surr. Ct. 1913); Matter of Marsland, 142 Misc. 230, 254 N.Y. Supp. 293 (Surr. Ct. 1931) ; Aubert's Appeal, 109 Pa. 447, 1 Atl. 336 (1885); In re de Von der Hallen's Trust, 169 N.Y.S.2d 698 (Special Term 1957) (Argentina). 
mon law forums by a reference to some other law- the law of the place of execution, the domicile at the time of execution, or even the situs and forum law. Resort to this broad choice-of-law is always made with the view of validating testamentary instruments rather than rendering them invalid. It seems, therefore, that in a multiple contact case it is actually the law validating the disposition which governs the formal validity of wills of movables.

First, most of the international cases in point have been decided under modern statutory law supposedly abrogating the domiciliary rule by the adoption of a broader option. However, the few cases whicl were decided during the early and middle nineteenth century and hence long before the enactment of such statutes, far from establishing the view that in the old common law formal validity was exclusively governed by the domiciliary law of the testator, seem to be based on a equally broad option. Thus, in Aubert's Appeal, ${ }^{88}$ testatrix died domiciled in Paris and left a will, executed in the French form in France, disposing of personal property situated in Pennsylvania. This will was admitted to probate in Pennsylvama as a valid will according to deceased's domicilary law at death. In Ex parte McCormick, ${ }^{89}$ testator and his wife executed a "conjoint" will in a Danish colony where they were domiciled, according to the forms of the Damish law. The husband died domiciled in New York and the will was offered for probate in that state where deceased's personal estate was also situated. This will, although not conforming to the law of the testator's domicile at the time of death, was admitted to probate as a valid testamentary instument according to the law of the testator's domicile at the time of execution. In Schultz $v$. Dambmann, ${ }^{90}$ a person domiciled in Germany executed a will in New York, designed to dispose of personal property situated in that state. This will, though invalid under the testator's domiciliary law, was admitted to probate in New York on the ground that the law of the place of execution governed formal validity. And in Dupuy v. Wurtz, ${ }^{, 1}$ a will invalid under the law of the place of execution and alleged domicile at death, France, was saved by a reference to the law of New York.

${ }^{88} 109 \mathrm{~Pa} .447,1$ Atl. 336 (1885) (the court partly relying on a power given to testatrix by a Pennsylvania donor to execute a testament "in the forms of her domicile"). See also Potter v. Titcomb, 22 Me. 300 (1843) (St. Croix, West Indies).

892 Bradf.Sur. 169 (N.Y. 1852).

803 Bradf.Sur. 379 (N.Y. 1855).

0153 N.Y. 556 (1873). Mrs. Wurtz, an American citizen, had been residing in France for twelve years when she executed a will in that country in the form prescribed by the laws of New York, the state of the situs of her real and personal property. When this will was offered for original probate in New York, interested parties contested its validity with regard to the personal property, on the ground that it did not conform with the formalities prescribed by the law of France-the country where deceased had been domiciled at death. Although the New York Court of Appeals agreed with the contestants' legal theory, it decided against them on the 
During the same period probate was denied in only two instances: in Grattan v. Appleton, ${ }^{92}$ to an instrument invalid under the law of the testator's domicile, the law of the place of execution, and the law of the situs and forum; and in Desesbats v. Berquier, ${ }^{93}$ to an instrument invalid under both the law of the place of execution and the testator's domicile.

Second, the New York Court of Appeals in Moultrie v. Hunt, ${ }^{04}$ an interstate conflicts case, declared that the formal validity of wills of movables was exclusively governed by the law of the testator's domicile at death. But by the time that case was decided, several states had already enacted statutes making use of alternative points of reference, ${ }^{95}$ and following that decision, New York itself acquiesced in the new trend by legislative action. Thus, the "common law" choice-of-law rule announced in Moultrie v. Hunt has long ago ceased to be the law either in the interstate or the international conflicts situation.

Third, today, as in the old common law days, an instrument executed in compliance with the forms prescribed by the law of the testator's domicile, the law of the place of execution, or the law of the situs of the personal property and forum, is generally admissible to probate..$^{98}$ In accordance with such hiberal doctrines, wills complying with only the law of the situs

ground that, contrary to much of the evidence, the deceased had had her domicile in New York. "Change of residence alone, however long continued," the court declared, "does not effect a change of domicile as regulating the testamentary acts of the individual" and "a mere declaration of intention not to return is not conclusive as to a change of domicile .... The intention to make such a change should be established by very clear proof, especially when the change is to a foreign coutrtry." Testatrix "desired to retain her domicile or origin," the court concluded, "and to have her estate administered according to the lawes of the state of New York." Id. at 565 (emphasis added).

9210 Fed. Cas. 992, No. 5707 (C.C. Mass. 1843), discussed in text at note 66 supro.

$932 \mathrm{Am}$. Dec. 448 ( $\mathrm{Pa} .1808)$, discussed in text at note 59 supra.

9423 N.Y. 394 (1861), discussed in text at note 67 stupro.

95 See, e.g., Irwin's Appeal, 33 Conn. 128 (1865). For present day legislation see Hopkins, The Extraterritorial Effect of Probate Decrees, 53 YaLE L.J. 221, 255 (1944). Practically tho first work of the National Conference of Commissioners on Uniform State Laws was the drafting of an act relating to the execution of wills. The UNIFORM WIIS ACT, ForEIGN EXreurED, promulgated in 1910 and adopted in thirteen states permitted adjustment to the law of tho enacting state, the lex loci actus, and the law of the domicile. See Handbook of Natronar. Conterence of Commasstoners on UnTFora State Laws 9 (1892); Rabel, The Form of Wills, 6 VAND. L. REv. 533 (1953); 9 U.L.A. 419 (1951). The UNIFORac Wris ACr was declared obsolete in 1940 because the substance of its provisions were included in $\S 7$ of the new MODEx EXECUTros of WIITS Acr, approved by the National Conference at the same time, which intended to unify the domestic requirements of the execution of wills, and thus to simplify the (interstate) conflicts problen. See 9 U.L.A. 420 (1951).

96 For a general view see Hopkins, The Extraterritorial Effect of Probate Decrees, 53 YaIE L.J. 221 (1944). If the will is invalid under all legal systems having contact with the succession, distribution will be made according to the rules governing intestate succession. See Matter of Lurcy, 207 Misc. 179, 136 N.Y.S.2d 549 (Surr. 1954), involving the will of an American citizen and New York resident which was executed in New York and invalid under both French (situs) law and New York (domiciliary) law. 
and forum were admitted to probate in several cases; ${ }^{n 7}$ wills complying with only the law of the domicile at time of execution, ${ }^{98}$ with only the law of the place of execution, ${ }^{99}$ with both the law of the domicile and that of the situs, ${ }^{100}$ and finally, with both the law of the domicile and that of the place of execution, ${ }^{101}$ have been admitted to probate in other cases.

\section{B. Essential Validity}

For a valid testamentary disposition of personal property not only must the testator's intention be expressed in a formal way guaranteeing genumeness of execution and freedom from coercion, but also a lawful scheme of distribution must be adopted. Thus, a domestic will, though admitted to probate, may nevertheless be wholly or partially ineffective to transfer title to personal property because it contains provisions which contravene certain rules, social standards, or interests of the forum. Such invaliditydepending upon compliance with "imperative" rules of the forum and fre-

97 Matter of Rubens, 128 App. Div. 636, 112 N.Y. Supp. 941 (1st Dep't 1908) (will of American citizen invalid under the domiciliary law and law of place of execution, France); Matter of McMulkin, 5 Dem. 295 (N.Y.Surr. 1886) (will of a Scotsman, executed in Scotland, invalid under Scottish law); Matter of Seabra, 18 Wkly Dig. 428 (Sup.Ct.N.Y. 1884) (will of a Portuguese citizen and domiciliary, executed in Portugal, invalid under Portuguese law); In re Smith's Estate, 48 N.Y.S.2d 631 (Surr. Ct. 1944) (will of American citizen domiciled in Spain, executed in Spain according to the law of New York) ; Matter of Coudert, 92 Misc. 109, 155 N.Y. Sup. 145 (Surr. Ct. 1915) (will of a French citizen and resident, executed in France according to the laws of New York). See also Matter of Cleveland, 28 Misc. 369, 59 N.Y. Supp. 985 (Surr. Ct. 1899) (France); Cruger v. Phelps, 21 Misc. 252, 47 N.Y. Supp. 61 (Sup. Ct. 1897) (France) (both wills, invalid under the law of the place of execution and alleged domicile at death, were saved by a finding of domicile within the forum jurisdiction). Cf. Palmer v. Bradley, 142 Fed. 193, 196 (N.D. Ill. 1905) (France); In te Clayton's Estate, 26 Wash. 253, 66 Pac. 410 (1901) (Canada).

98 Matter of Hansgirg, 196 Misc. 948, 94 N.X.S.2d 26 (Surr. Ct. 1949) (Manchuria).

${ }^{99}$ de Garmendia's Estate, 146 Md. 47, 125 Atl. 897 (1924) (France); In re de Franceschi's Estate, 17 Tenn. App. 673, 70 S.W.2d 513 (1933) (Italy) ; Matter of Fowler, 161 Misc. 204, 291 N.Y. Supp. 639 (Surr. Ct. 1936) (France) ; Matter of Speyer, 176 Misc. 419, 27 N.X.S.2d 603 (Surr. Ct. 1941) (Germany); Matter of Hansgirg, 196 Misc. 948, 94 N.Y.S.2d 26. (Surr. Ct. 1949) (Korea-Manchuria); Matter of Tallmadge, 109 Misc. 696, 181 N.Y. Supp. 336 (Surr. Ct. 1919) (France) ; Matter of Logasa, 161 Misc. 774, 293 N.Y. Supp. 116 (Surr. Ct. 1937) (France). See also In re Eighmie's Will, 201 N.Y. Supp. 876 (Surr. Ct. 1923) (England) ; Succession of Drysdale, $124 \mathrm{La} .256,50$ So. 30 (1909) (Canada), reversed on other grounds, $127 \mathrm{La}$. 890, 54 So. 138 (1910); In re Marques' Will, 123 N.Y.S.2d 877 (Surr. 1953) (interstate).

100 New York Life Ins. and Trust Co. v. Viele, 161 N.Y. 11, 55 N.E. 311 (1899) (will of American citizen executed in Germany according to the forms of the law of New York, the domiciliary state).

101 Matter of Wizelholc, 176 Misc. 100, 26 N.Y.S.2d 586 (Surr. Ct. 1941) (Poland); Lindsay v. Wilson, 103 Md. 252, 63 Atl. 566 (1906) (France); Olivet v. Whitworth, 82 Md. 258, 33 Atl. 723 (1896) (Switzerland); see also In re Wiener's Will, 120 N.Y.S.2d 774 (Surr. 1953); Matter of Stein, 119 Misc. 9, 194 N.X. Supp. 909 (Surr. 1922) (interstate). Cf. Matter of Banta, 204 Misc. 985, 128 N.Y.S.2d 334 (Surr. Ct. 1953) (testamentary instrument executed in Canada was denied probate in New York as having not compled with either the law of New York or the law of Canada). 
quently arising out of the nature of the disposition-is termed, in contrast to the formal validity discussed above, essential invalidity. ${ }^{102}$

The Restatement laying stress on the courts' seemingly consistent recognition of the domiciliary rule rather than on its adjustment to varying fact situations, declares that the essential validity of a will of movables is governed by the law of the testator's domicile at death. ${ }^{103}$. It seems, however, that all international cases in point have been decided in accordance with a much broader choice-of-law rule and that whenever the will does not violate superior policies of the forum essential validity is governed by the law upholding the will. To this effect, the law of the testator's or the beneficiary's domicile, the law of the place where a trust of movables is to take effect, and the situs and forum law, are consistently and uniformly applied by the American courts.

These common law choice-of-law rules will be traced in the following discussion of selected problems of essential validity: first, capacity to dispose and to receive; second, charitable bequests; third, unknown and forbidden interests; and fourth, forced heirship. ${ }^{104}$ Other issues such as the intervention of fraud and undue influence or the effect of a subsequent marriage and birth of child will not be considered here since it is believed that the question of fraud in most instances is inainly one of fact to be proved and not of applicability of foreign law, ${ }^{105}$ and that the subsequent marriage or birth of child raises in common law a question of revocation rather than essential validity. ${ }^{106}$

\section{Capacity}

While the civil law has developed a general concept of "capacity" based on an individual's personal law and embracing almost all inter vivos and

102 The term "essential validity" is largely undefinable, and in effect indicates a conclusion of law, i.e., that a formally valid testamentary instrument will be carried into effect. Cf. I JARMLAN, WIIIS 5 (8th ed. 1951) ("efficacy of the testamentary dispositions"). See also CuESmIRE, Private International Law 532 (1952); Dicey, Conflict of Laws 855 (1949); Goodruch, CONFLICT OF LAWS 512 (1949).

103 Restatement, Conflict of LAWS $\$ 306$ (1934); cf. notes 25-28 supro.

104 Forced heirsbip is sometimes classified as a matter of "capacity to dispose." Cf. Trimble v. Dzieduzyiki, 57 How. Pr. 208 (N.Y. 1878), note 113 infra. The matter will be separately dealt with because of its great practical significance and bccause it involves the clash of strong policies which may affect a differentiation of the rules governing other issues of essential validity. 105 See Matter of Cruger, 36 Misc. 477, 73 N.Y. Supp. 812 (Surr. Ct. 1901), where the will of an American citizen domiciled in France was contested partly on the grounds of fraud and undue influence and the court disposed of those issues as questions of fact without reference to choice-of-law rules. See also Matter of Lang, 9 Misc. 521, 30 N.Y. Supp. 388 (Surr. Ct. 1894); Succession of Drysdale, 127 La. 890, 54 So. 138 (1910); Matter of Moran, 180 Misc. 469, 39 N.Y.S.2d 929 (Surr. Ct. 1943) ; Matter of Cleveland, 28 Misc. 369, 59 N.Y. Supp. 985 (Surr. Ct. 1899) ; cf. Breslauer, Private Internationat Law of Succession 180 (1937).

106 See text at note 370 infra. 
causa mortis transactions, ${ }^{107}$ at common law the issue of "capacity" is determined only in connection with the particular transaction in which the question arises. ${ }^{108}$ Thus, the capacity to dispose and to receive personal property by testamentary act is considered a matter of inheritance, allegedly governed by the law of the testator's domicile at death. ${ }^{109}$

(a) Capacity to dispose. The term "capacity to dispose" or "testamentary capacity" has been used by the courts in the sense of "mental capacity," 110 capacity as a matter of "age" or "status," 111 and capacity to dispose of property "generally" 112 ('m the absence of descendants' rights to a forced share) or "for specific purposes"113 (in the absence of a prohibition of charitable bequests).

If the question is "whether a decedent is capable of sufficient thought, reflection, and judgment to know of the property he has, and to decide and declare what shall be done with it" 114 - that is, mental capacity-it would seem that no conflicts problem is involved; ${ }^{115}$ the question in such a case is one of fact to be proved by competent evidence. ${ }^{116}$ Capacity "to dispose of property generally" will be dealt with as a matter of forced heirship; ${ }^{117}$

107 Cf. Batrffor, Droit Internationat Privé 667 (1949); 4 Frankenstend, Internationates Privatrecet 417 (1935); Nussbaum, Deutches Internationates Privatrecht 118 (1932); 1 Putret, Droit International Prux́ 486 (1923).

108 See 2 Beale, Conflict of Laws 660 (1935); Fatconbrdoge, Conflict of Laws 121

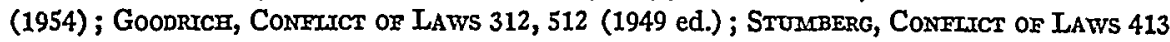
(1951); Wolf, Private InternationaI Law 591 (1946).

109 See Restatenient, Conflict of Laws $\$ 306$, comment $b$ (1934); 2 Beare, Confutct or Laws 1035 (1935); Goodrich, Conflict of LaWs 512 (1949 ed.); 4 Paige, WIIIS 705 (1941). 110 See Matter of Lang, 9 Misc. 521, 30 N.Y. Supp. 388 (Surr. 1894); Matter of Moran, 180 Misc. 469, 39 N.Y.S.2d 929 (Surr. Ct. 1943) ; Matter of Cruger, 36 Misc. 477, 73 N.Y. Supp. 812 (Surr. Ct. 1901); Schweitzer v. Bean, 154 Ark. 228, 242 S.W. 63 (1922) (interstate). 111 See Roberts' Succession, 2 Rob. 427 (La. 1842). Cf. Schultz v. Dambmann, 3 Bradf.Sur. 379 (N.Y. 1885) ("general capacity to make a will").

112 See Trimble v. Dzieduzyiki, 57 How. Pr. 208 (N.Y. 1878), discussed in text at note 207 infra. See also Schultz v. Dambmann, 3 Bradf.Sur 379 (N.Y. 1885) (distinguishing between "the general capacity to make a will" and "the disposable power over the estate"). The case is discussed in text at note 226 infra.

113 See Pottstown Hospital v. New York Life Ins. and Trust Co., 208 Fed. 196 (S.D.N.Y. 1913); Chamberlain v. Chamberlain, 43 N.Y. 424 (1871). Statutes regulating charitable bequests, however, are at times construed as involving capacity to receive rather than capacity to dispose. $C f$. text at notes 151,162 infra.

114 Matter of Lang, 9 Misc. 521, 30 N.Y. Supp. 388 (Surr. Ct. 1894).

116 See Higgins v. Eaton, 202 Fed. 75 (2d Cir. 1913) ("... the question of capacity is one of local law and the law of the domicile is no longer controlling ....); Matter of Lang, 9 Misc. 521, 30 N.Y. Supp. 388 (Surr. Ct. 1894).

110 See Matter of Cruger, 36 Misc. 477, 73 N.Y. Supp. 812 (Surr.Ct. 1901); Matter of Lang, 9 Misc. 521, 30 N.Y. Supp. 388 (Surr. Ct. 1894) ; Schweitzer v. Bean, 154 Ark. 228, 242 S.W. 63 (1922) (interstate); Hebert v. Winn, 24 La. Ann. 385 (1872) (interstate); cf. Slougb, Testamentary Capacity: Evidentiary Aspects, 36 Texas L. REv. 7 (1957).

117 See text at note 183 infra. 
and capacity to dispose of property "for specific purposes" will be discussed in connection with the issue of validity of charitable bequests. ${ }^{118}$ We are thus concerned at this point with the intended testator's capacity as a matter of age or status.

Several dicta may be cited to the effect that such capacity is governed by the law of the testator's domicile at death. ${ }^{110} \mathrm{But}$ in the only international case in point, Roberts' Succession, ${ }^{120}$ the issue was determined according to the law that gave full effect to the intention of the testatrix. Maria Josepha Robert, an illegitimate child born in Louisiana, was sent to France at the age of six. She died in that country fifteen years later, having executed a will in the French language disposing of personal property situated in Louisiana. Testatrix directed that all that the law permitted her to give be given to her intended husband. This will was originally probated in Louisiana; and the courts of that state were requested to determine the capacity of the testatrix to dispose of her estate. Had this capacity been determined under the law of France, the will could pass only one-half of the estate because testatrix was a minor at the time of execution of the will and according to French law she could dispose of only that portion. Were the issue, on the other hand, to be determined according to Louisiana law, the will would pass the entire estate, since under that law testatrix had full testamentary capacity. The court, disregarding the contentions of the natural mother of the testatrix that her daughter was emancipated and had acquired a domicile of choice in France, held that testatrix was legally domiciled in Louisiana and that her capacity should be determined accord-

\footnotetext{
118 See text at note 143 infra.
}

110 See Ex parte McCormick, 2 Bradf.Sur. 169 (N.Y. 1852) (involving formal validity of a foreign executed will by a Danish citizen); In re Harwood, 104 Misc. 653, 172 N.Y. Supp. 296 (Surr. Ct. 1918) (involving ancillary proceedings and recognition of foreign probate); Matter of Roberts' Will and Codicil, 8 Paige 519 (N.Y. Ch. 1840) (involving formal validity of a foreign executed will of a Cuban domiciliary). See also Matter of Moran, 180 Misc. 469, 39 N.Y.S.2d 929 (Surr. Ct. 1943). Testator, a former American citizen allegediy domiciled in New York, died in Cuba. A will executed in Cuba and "protocolized" there as the will of a resident, was admitted to ancillary probate in New York where a large personal estate belonging to decedent was situated. Testator's widow at a subsequent proceeding sought to annul this ancillary probate on the ground of "decedent's lack of testamentary capacity and fraud and undue influence practiced upon him" and offered for original probate in New York an earlier will executed in that state. The court apparently confused the issue of choice-of-law with that of "local" and "international" jurisdiction (supra note 24), and declined to adjudicate the issue of capacity prior to a showing that testator died domiciled in New York. A trial for the determination of this prejudicial issue was ordered with the instruction that "A finding of no domicile here would impel this Court to decline to try the question of the validity of the Cuban will and to remit such question to the Cuban courts."

1202 Rob. 427 (La. 1842). See also Estate of Sloan, 7 Cal. App. 2d 319, 46 P.2d 1009 (1935) (interstate). 
ing to the law intended by testatrix to govern her capacity anyway. ${ }^{121} \mathrm{Ac}$ cordingly, the entire estate was awarded to the designated beneficiary. (b) Capacity to Receive. The term "capacity to receive" has been used by the courts in the sense of general capacity of the beneficiary to take and hold property ${ }^{122}$ and of what we may call "specific" capacity of charitable associations to receive bequests in the absence of a mortmain statute. ${ }^{123}$ The second, specific capacity, is discussed in connection with the issue of validity of charitable bequests; ${ }^{124}$ we are presently interested in a beneficiary's general capacity to receive a legacy.

No international case has been found involving determination of an individual's capacity to receive. ${ }^{125}$ All the cases in point involve determination of the general capacity of municipalities, corporations, unincorporated associations and boards to receive, in trust ${ }^{126}$ or absolutely, ${ }^{127}$ bequests for charitable purposes. However, since the courts do not distinguish between corporate and individual or charitable and non-charitable beneficiaries we may fairly assume that the same choice-of-law rules are applicable in all situations. ${ }^{128}$

The Restatement regards the capacity of a legatee to receive his legacy as a matter of inheritance, governed by the testator's domiciliary law at

121 See id. at 437. "It seems to us clear, that the testatrix intended to bequeath all that she was capable of giving, and that nothing in her disposition, or in the expression of her last will, indicates that the law by her alluded or referred to, if indeed she alluded or referred to any particular law, was the law of France rather than that of Louisiana. It is true her residence de facto was in France, but she had no property there, beyond her wearing apparel and some furniture; and if she had really intended to dispose according to the law of that country, would it not have been easy for her to ascertain exactly the extent of her capacity there? Her disposition shows an entire ignorance of the law that was to govern her capacity; and we inay fairly presume that she did not know which was to have that effect. But certain it is that it evinces clearly the intention of bequeathing to ... her intended husband, all she could legally give to him, and the whole of her estate if it happened that she was by law permitted to do so.... Her intention was undoubtedly to dispose to the full extent of her legal capacity; and if so, how could her intention be separated from her capacity? Is not the one, on the contrary, closely connected with the other? We think so. ..."

122 This "general capacity" includes the concepts of "Inental" capacity and capacity as a matter of age or status. $C f$. text at notes 110-11 supra.

${ }^{123} \mathrm{Cf}$. text at note 147 infra.

124 See text at note 157 infra.

125 Cf. Harding v. Schapiro, 120 Md. 541, 87 Atl. 951 (1913), discussed in text at note 348 infra.

126 Bequests, in trust, inay conflict with either mortınain statutes or statutes prohibiting perpetuities. $C f$. text at notes 159,168 infra.

127 Whenever the bequest is absolute, no prohibition against perpetuities is involved. But still there may be violation of a mortmain statute. $C f$. text at note 151 infra.

128 See cases cited in notes 132-42, 175-76 infra. See also In re Chappell's Estate, 124 Wash. 128, 132, 213 Pac. 684, 685 (1923): "While the courts are very keen sighted to discover the intent to make a charitable bequest, and very solicitous to give effect to such intent, still we know of no reason why the courts should not be equally solicitous to give effect to any other lawful intent on the part of the testator which can be clearly gathered from the will"; LAND, Trusts IN TEE CoNFiICT of Laws 59, 75 (1940). 
death. ${ }^{129}$ But, while this view finds support in a number of cases, the alleged rule is contradicted by other cases which regard this capacity as a matter of "personal" law of the beneficiary, governed by his domiciliary law. ${ }^{130}$

Whenever the beneficiary has general capacity to receive and hold property under his own domiciliary law, such capacity will be determined and the disposition upheld under that law. ${ }^{131}$ The question is most frequently raised in cases involving capacity of a foreign domiciliary to receive a bequest made in the will of a resident testator. Thus, the capacity of a Scottish mumicipality to take a legacy given by a Louisiana testator was determined and the disposition upheld under Scottish law; ${ }^{132}$ the capacity of a Swiss nuunicipality to receive a bequest made by a Louisiana testator, under Swiss law; ${ }^{133}$ the capacity of a German mumcipality to receive a bequest given by a New York citizen under German law; ${ }^{134}$ and, the capacity of an Australian beneficiary to take a bequest made by a New York citizen under Australian law. ${ }^{135}$ Similarly, a bequest by a New York citizen to an English unincorporated religious association was upheld under English law, the court declaring that "the power to take the bequest, is governed by the law of the place where the purpose is to be performed, or where the donee resides." ${ }^{136}$ And a legacy left by a New York testator to an apparently unincorporated German beneficiary was upheld under German law with a holding that "the law of the legatee's domicile controls as to his capacity to receive and as to the validity of the bequest." ${ }^{137}$

The same choice-of-law rule is also applicable in the rather uncommon converse situation where the capacity of a domestic beneficiary to receive a bequest made in the will of a non-resident is an issue. If such capacity

129 RestaTEMENT, Confurct of LAWs $\S 306$, comment $b$ (1934). The same comment specifies that "in case of a legacy to a corporation, the question whether the acceptance of the terms of the gift is within the purposes of incorporation is determined by the law of the state of incorporation." See also 2 BEAIE, Conflict of Laws 1036 (1935); Goodrich, Conflict of Laws 516, 518 (1949 ed.) ; 4 Page, WIIS 716 (1941).

130 See Matter of Huss, 126 N.Y. 537, 27 N.E. 784 (1891) ("The ability to take a testamentary bequest depends upon the law of the legatee's domicile"); cases cited in notes 131-39 infra. See also Wearton, Conflict of Laws 1354 (1872 ed.); Cheshure, Prtyate InternaTTONAL LAW 522 (1952); Note, 91 A.L.R. 491, 492 (1934); 65 L.R.A. 181 (1904).

131 See Matter of Lang, 9 Misc. 521, 30 N.Y. Supp. 388 (Surr. Ct. 1894) ("The law of the legatee's domicile controls as to the validity of the bequest, and the courts of this State will recognize a bequest, which, if made to a legatee here, would be illegal, as valid when given to a legatee entitled to take under the laws of his domicile").

132 Duke of Richmond v. Milne's Ex'rs, 17 La. 312 (1841).

133 Succesion of Meumer, 52 La. Ann. 79, 26 So. 776 (1899).

134 Matter of Huss, 126 N.Y. 537, 27 N.E. 784 (1891).

135 Matter of Grant, 200 Misc. 35, 101 N.Y.S.2d 423 (Surr. Ct. 1950); see also Kurzman

v. Lowy, 23 Misc. 380, 52 N.Y. Supp. 83 (Sup. Ct. 1898).

136 Matter of Merritt, 273 App. Div. 79, 75 N.Y.S.2d 828 (4th Dep't 1947).

137 Matter of Lang, 9 Misc. 521, 30 N.Y. Supp. 388 (Surr. Ct. 1894). 
exists under the forum and beneficiary's domiciliary law, the issue will be determined, and the disposition upheld, under that law. Thus, a bequest by an American citizen domiciled in England to "American charities" and "to poor needlewomen," allegedly invalid under English domiciliary law, was upheld under New York law; ${ }^{138}$ and where a domiciliary of Peru made a bequest to the "Sevilla home of children" to be founded in New York, the general capacity of the beneficiary was determined under New York law. ${ }^{139}$

In contrast, if the beneficiary lacks capacity to receive under his own domiciliary law the disposition will be given effect under the law of the testator's domicile. Thus, a bequest by a New York domiciliary to a German charity was upheld under New York law over the objections of the executor that the beneficiaries "became non-existent" and the trustees "incompetent to act." "If there were inability of the trustees to take," the court said, "the trust would nevertheless be subject to administration .... The court will enforce such gifts as that here made."140 Similarly, a bequest to a French religious seminary allegedly lacking capacity to receive under French law was upheld under the law of New York, the situs and domicile of the testator. ${ }^{141}$ And a bequest by a Mimnesota testator to a Swedish religious association which lacked capacity to receive under the law of Sweden was saved under Minnesota law. ${ }^{142}$

138 Manley v. Fiske, 139 App. Div. 665, 124 N.Y. Supp. 149 (1st Dep't 1910). The legal theory of the court is not clear. The court said that "under the law of England and the state of New York the validity or invalidity of the attempted charitable bequest is to be determined according to the law of the place where the gift is to take effect." This statement, however, does not explain the application of New York law.

The action of the New York court can be explained under three different theories: First, that situs law was applied without consideration of choice-of-law principles. This can be made by a broad delimitation of the forum and situs law, as covering all property within the jurisdiction. Second, it may be that situs law was applied following a choice-of-law rule of the forum referring the issue of the validity of the bequest to the law of the place where the assets were situated. And third, it may be that the court applied situs law on a renvoi theory. Following a choice-of-law rule of the forum which referred the issue of validity of the bequest to the domiciliary law of the testator (England), the court interpreted this reference as including English conflicts law and upheld the disposition under the law of New York, the law governing validity according the English choice-of-law principles. $C f$. text at note 283 infra.

139 Dammert v. Osborn, 140 N.Y. 30, 35 N.E. 407 (1893). Cf. text following note 173 infra. 140 Matter of Dreyfuss, 154 Misc. 47, 276 N.Y. Supp. 438 (Surr. Ct. 1934). See also Matter of Bell, 141 Misc. 720, 253 N.Y. Supp. 118 (Surr. Ct. 1931) (bequest by New York domiciliary to an unincorporated Irish church upheld under New York law).

141 Matter of Miller, 149 App. Div. 113, 133 N.Y. Supp. 828 (1st Dep't 1912). See also Matter of Lamborn, 171 Misc. 734, 13 N.Y.S.2d 732 (Surr. Ct. 1939) (interstate).

142 In re Henrikson's Estate, 163 Minn. 176, 203 N.W. 778 (1925). But cf. Matter of Crum, 98 Misc. 160, 164 N.Y. Supp. 149 (Surr. Ct. 1916). Testator, a New York citizen, left his residuary estate "to the Wildenthierbach," a parish or a village in the Kingdom of Wïrtenberg, Germany. The bequest was held invalid under the law of New York as too indefinite, and under the law of Germany as made to a beneficiary lacking capacity to receive. 


\section{Charitable Bequests}

Charitable bequests, though generally favored by the law, ${ }^{143}$ are subject to specific prohibitions and restrictions ${ }^{144}$ arising from the pursuit of various domestic policies embodied in several kinds of statutes. Thus, a charitable bequest may be ineffectual because of the violation of a statute prohibiting bequests to charities during a specified period of time before death designed to safeguard testator's freedom from undue influence ${ }^{146}$ a statute restricting a testator's freedom to leave property to charities when he is survived by certain relatives enacted for the protection of close relatives; ${ }^{146}$ a mortmain statute aimed at preventing accumulation of wealth in the hands of powerful associations $;^{147}$ or finally, a statute prohibiting perpetuities aimed at securing free alienability of estates. ${ }^{148}$

It is commonly accepted that "the validity of the attempted charitable bequest is to be determined according to the law of the place where the gift is to take effect." ${ }^{140}$ Indeed, this rule has been followed in the great majority of cases; but, in certain instances, bequests invalid under the law of the place where the gift would take effect have been saved by a reference to the domiciliary law of the testator. It seems, therefore, that the courts actually apply the law validating the charitable bequest. ${ }^{150}$ In this respect, a

143 "Charitable trusts are highly favored, and a liberal construction will be adopted in order to render them effectual." Hagen v. Sacrison, 19 N.D. 160, 123 N.W. 518 (1909). See also Matter of Antoni, 186 Misc. 988, 61 N.Y.S.2d 349 (Surr. Ct. 1946); Succession of Meunier, 52 La. Ann. 79, 26 So. 776 (1899); Dammert v. Osborn, 140 N.Y. 30,35 N.E. 407 (1893).

144 See in general Joslin, Confict of Laws Problems Raised by "Modern Mortmain Acts," 60 Dick. I. REV. 7 (1955).

145 See Rhennstein, Cases on Decedents' Estates 98 (2d ed. 1955); Joslin, Conflict of Laws Problems Raised by "Modern Mortmain Acts," 60 Dick. L. Rev. 7, 11 (1955); Note, 91 A.L.R. 491, 496 (1934).

${ }^{146}$ See Dammert v. Osborn, 140 N.Y. 30, 40, 35 N.E. 407, 410 (1893). "There are other statutes that invalidate testamentary gifts to certain corporations ... where the testator had wife, children, or parents. The purpose of these statutes is evident. They were intended to prevent improvident and hasty bequests, to the prejudice or neglect of those natural obligations which the law also imposes upon the citizen." See also Note, 91 A.L.R. 491, 501 (1934).

147 See Rhennstein, Cases on Decedents' Estates 112, 114 (2d ed. 1955). Cf. Hope v. Brewer, 136 N.Y. 126, 132, 32 N.E. 558, 561 (1892) ("It was said of the English Statute of Mortmain that its object was political, and intended to have but a local operation. It was enacted to prevent what was deemed a public mischief and not to regulate, as between ancestor and heir, the power of disposing by will, or to prescribe as between grantor and grantee the forms of alienation. It is an incident only, and with reference to a particular object, that the exercise of the owner's dominion over his property is abridged.").

148 See Rheinsters, Cases on Decedents' Estates 133 (2d ed. 1955).

149 Manley v. Fiske, 139 App. Div. 665, 124 N.Y. Supp. 149 (1st Dep't 1910). See also In re Stepbani's Estate, 300 N.Y. Supp. 813 (Surr. Ct. 1937); Matter of Crum, 98 Misc. 160, 164 N.Y. Supp. 149 (Surr. Ct. 1916).

150 Cf. Hope v. Brewer, 136 N.Y. 126, 32 N.E. 558 (1892). "This result, I think, is in harmony with the tendency of courts to sustain testamentary dispositions of property when it fairly can be done under the rules of law, and in accordance with principles of enlightened justice." See also Beach v. Gilbert, 133 F.2d 50 (D.C. Cir. 1943) (interstate); Joslin, Conflict of Laws Problems Raised by "Modern Mortmain Acts," 60 Drck. L. Rev. 5, 11 (1955). 
flexible characterization of the issue as involving capacity to receive, believed to be governed by the law of the beneficiary's domicile, or capacity to dispose, allegedly governed by the law of the testator's domicile, is a technique commonly employed ${ }^{151}$ to accommodate the conflicting policies of the forum-the policy favoring freedom of disposition and the policy underlying the particular prohibition.

Whenever the will violates a statute of either the forum and situs or the domiciliary state designed to safeguard testator's freedom from undue influence one would expect that, in most instances, the bequest should be declared invalid. ${ }^{162}$ The courts, however, have construed such restrictions as applicable only in exclusively domestic successions and following a characterization of the issue as involving capacity to receive or capacity to dispose according to the circumstances have managed to uphold the disposition under the most favorable law. ${ }^{153}$

When a statute designed to protect the dependents of a testator is violated, the residence of those dependents within the jurisdiction should be a significant consideration in the determination of the validity of the charitable bequest in view of the fact that such statutes are primarily enacted for the protection of residents. ${ }^{154}$ But, without regard to the dependents' residence, the courts, as in cases involving forced heirship rights, are inclined to apply the law upholding the disposition made by the testator. ${ }^{155}$ Accordingly, the issue is frequently characterized as involving capacity to receive if the bequest is valid under the law of the beneficiary's domicile and capacity to dispose if the bequest is valid under the law of the testator's domicile. ${ }^{158}$

${ }^{161} \mathrm{Cf}$. note 113 supra; notes $153,156,162,172$ infra.

162 See Joslin, Confict of Laws Problems Raised by "Modern Mortmain Acts," 60 Drck. L. REv. 5, 11 (1955); Note, 91 A.L.R. 491, 501 (1934). Cf. Succession of Herber, 128 La. 111, 54 So. 579 (1911) (will of Mississippi citizen invalid under Louisiana law) ; Kerr v. Dougherty, 79 N.Y. 327 (1880) (will of New York citizen invalid under Pennsylvania law).

163 See, e.g., Hildeburn's Estate, $16 \mathrm{~Pa}$. County Ct. 39 (1894) (capacity to dispose) ; Pottstown Hospital v. New York Life Ins. and Trust Co., 208 Fed. 196 (S.D.N.Y. 1913) (capacity to receive). But ef. Succession of Herber, 128 La. 111, 54 So. 579 (1911) (incapacity to receive); Kerr v. Dougherty, 79 N.X. 327 (1880) (incapacity to receive and to dispose).

154 Cf. text at note 245 infra.

$155 \mathrm{Cf}$. text at note 257 infra. See Estate of Layton, 217 Cal. 451, 19 P.2d 793 (1933); Chamberlain v. Chamberlain, 43 N.Y. 424 (1871); Johns Hopkins University v. Uhrig, 145 Md. 114, 125 Atl. 606 (1924); Reed's Will, 48 Ore. 500, 87 Pac. 763 (1906); Crnn v. Bliss, 47 Conn. 592 (1880). But cf. Estate of Lathrope, 165 Cal. 243, 131 Pac. 752 (1913).

158 In Damnert v. Osborn, 140 N.Y. 30, 35 N.E. 407 (1893), discussed in text following note 173 infra, the party invoking New York law to invalidate a bequest made by a citizen of Peru to a New York charity was a non-resident. The New York court classified the issue of validity as involving capacity to dispose and upheld the disposition under the domiciliary law of the testator. Cf. id. at 410. See also Note, 91 A.L.R. 491, 496 (1934); Joslin, Confict of Laws Problems Raised by "Modern Mortmain Acts," 60 Drck. L. REv. 7, 14, 18 (1955); Crum v. Bliss, 47 Conn. 593 (1880) (capacity to dispose); Chamberlain v. Chamberlain, 43 N.Y. 424 
In several states, charitable associations are forbidden to receive gifts above a certain amount or to hold property or land above a certain value either unconditionally, or without government permission. ${ }^{167}$ These mortmain statutes are designed to prevent the accumulation of wealth in the hands of religious and other associations within the jurisdiction. ${ }^{158}$ Consequently, the only relevant consideration in a multiple contact case involving violation of a mortmain statute should be the law of the place where the bequest is to take effect; if valid under that law the bequest will be generally given effect without regard to the situs and forum or the domiciliary prohibition..$^{159}$ But, like statutes prohibiting perpetuities, ${ }^{100}$ mortmain restrictions are narrowly delimited and their policy is never carried to its logical conclusion. Accordingly, courts sitting in a jurisdiction having a mortmain statute generally uplold the disposition without regard to the law of the place where the bequest is to take effect if it is valid under the domiciliary law of the testator. ${ }^{161}$ To this effect, a characterization of the issue as involving capacity to dispose rather than capacity to receive is frequently made. ${ }^{102}$

A charitable bequest may also be ineffectual because of the violation of a statute designed to secure free alienability of estates. This invalidity -in contrast to that arising from the violation of statutes designed to protect testator's freedom from undue influence, the testator's dependents from

(1871) (capacity to receive). Cf. Johns Hopkins University v. Uhrig, 145 Md. 114, 125 Atl. 606 (1924). In California, where a statutory provision makes forum law applicable, the restriction is relazed to some extent by the determination of the disposable portion on the basis of the entire estate wherever situated. See Estate of Dwyer, 159 Cal. 680, 115 Pac. 242 (1911); Estate of Sloane, 171 Cal. 248, 152 Pac. 540 (1915) ; Estate of Lathope, 165 Cal. 243, 131 Pac. 752 (1913). But cf. Estate of Layton, 217 Cal. 451, 19 P.2d 793 (1933).

157 See Zorrman, American Law of ChartTies (1924) ; Rhetnstenn, Cases on Decedents' Estates 135 (1955); Thompson v. Swoope, 24 Pa. 474 (1855).

158 See Vansant v. Roberts, 3 Md. 119, 129 (1852) ("This provision in our Bill of Rights, was designed for the protection or benefit of the people of Maryland ... (We) cannot see why it should be a matter of concern to Maryland that the personal property of her citizens should not pass away to foreign corporations any more than to individuals living abroad ... These are questions to be regulated by each state for itself") ; Chamberlain v. Chamberlain, 43 N.Y. 424 (1871).

159 Vansant v. Roberts, 3 Md. 119 (1852); Chamberlain v. Chamberlain, 43 N.Y. 424 (1871); Thompson v. Swoope, 24 Pa. 474 (1855); Matter of Merritt, 273 App. Div. 79, 75 N.Y.S.2d 828 (4th Dep't 1947); Matter of Lamborn, 171 Misc. 734, 13 N.Y.S.2d 732 (Surr. Ct. 1939).

$160 \mathrm{Cf}$. text at note 163 infra.

161 See Crum v. Bliss, 47 Conn. 592 (1890); cases cited note 162 infra. Butt cf. Mapes v. American Home Missionary Society, 33 Hun 360 (N.Y. 1884).

162 See Thompson v. Swoope, $24 \mathrm{~Pa} .474$ (1855) (capacity to dispose) ; Matter of Merritt, 273 App. Div. 79, 75 N.Y.S.2d 828 (4th Dep't 1947) (capacity to receive). See also Vansant v. Roberts, 3 Md. 119 (1852); Chamberlain v. Chaunberlain, 43 N.Y. 424 (1871); Matter of Lamborn, 171 Misc. 734, 13 N.Y.S.2d 732 (Surr. Ct. 1939). But of. Mapes v. American Home Missionary Society, 33 Hun 360 (N.Y. 1884) (incapacity to receive). 
pauperization, or accumulation of wealth in the "dead hand" of religious associations-is not peculiar to charitable bequests. We shall consider that issue, therefore, in the following discussion of unknown and forbidden interests.

\section{Unknown and Forbidden Interests: Validity of Trusts of Movables}

According to the Restatement, "the validity of a trust of movables created by a will is determined by the law of the testator's domicile at the time of death." 163 The American courts, however, in order to give effect to the testator's intention and save the disposition, resort to a much broader choice-of-law by referring the issue of validity of a testamentary trust of movables to the law of the place where the trust is to take effect, the domicile of the testator, or the situs of the personal property. ${ }^{164}$

(a) The rule against perpetuities. Most international cases concern domestic wills creating trusts valid under the law of the foreign place where the bequest is to take effect but invalid under the forum, situs, and domiciliary law of the testator, prohibiting perpetuities and accumulations. In this category of cases such prohibitions have been construed as regulating ca-

163 Restatemmant, Confutct of Laws $\$ 295$ (1934). Comment $a$ explains that "this is an instance of the type of problem involved in determining the validity of a will of movables and is treated in §306." See also 2 BEate, Confuicr of Laws 1035 (1935) ; Goodrich, Confurcr of LAws 516 (1949 ed.); 4 PAgE, Wirs 722 (1941); Beale, Equitable Interest in Foreign Property, 20 Harv. L. Rev. 382 (1907). But cf. Equitable Trust Co. v. Ward, 29 Del. Ch. 206, 48 A.2d 519 (1946) ("While the domicile of the donor is a circumstance to be considered in determining the seat of a trust, it is no longer regarded as the decisive factor."); In re Grant's Will, 101 N.Y.S.2d 423, 426 (Surr, Ct. 1950).

Most international cases involve determination of the validity of charitable trusts; and only a few, trusts for the benefit of private individuals. But, although some writers suggest that with respect to charitable trusts "standards ordinarily employed may be deemed to be inapplicable" (Stumberg, Confurct of Laws 418 (1951); Goodrich, Confurct of Laws 517 (1949 ed.) ; Joslin, Conflict of Laws Problems Raised by "Modern Mortmain Acts," 60 Drck. L. REv. 5,19 (1955)), no such distinction is inade by the courts. See Equitable Trust Co. v. Ward, 29 Del. Ch. 206, 48 A.2d 519 (1946) ("Most of the cases applying that rule (i.e., that the validity of a trust of movables is determined according to the most favorable situs law) involve charitable trusts, but it is not limited to cases of that nature.") ; In re Grant's Will, supra. See LAND, TRUSTS IN THE CONFLICT OF LAWS 59 (1940); note 128 supra. Accordingly, the choice of law rules governing both charitable and non-charitable trusts are discussed together.

164 Distinction is ordinarily made with respect to instruments exercising a power of appointment over a trust of movables; the essential validity of such instruments is allegedly governed by the law of the donor's domicile. See GoodricH, ConfLICT OF Laws 529 (1949 ed.); Brestauer, Prtvate International Law of Succession 182 (1937); Stumiberg, Conflict of LAws 429 (1951) ; Wharton, CONFLICT OF Laws 441 (1871 ed.). But cf. RestateMent, CoNFLICT OF LAWS $\$ 287$ (1934); 2 BEALE, CONFLICT OF LAWs 1010 (1935) (donor's or donee's domiciliary law); Note, 38 HARv. L. Rev. 661, 667 n.26 (1925) (situs law). It seems, however, that the essential validity of wills exercising powers of appointment is governed by the law validating the disposition. See Gallard v. Winans, 111 Md. 434, 74 Atl. 626 (1909) (France); Matter of Marsland, 142 Misc. 230, 254 N.Y. Supp. 293 (Surr. Ct. 1931) ; In re Barnhart's Will, 137 Misc. 518, 244 N.Y. Supp. 130 (Surr. Ct. 1930) (Canada) ; Ameritage v. Attorney General, 324 Mass. 648, 88 N.E.S. 126 (1949) (interstate). Cf. text at notes 330, 304 infra. 
pacity to receive rather than capacity to dispose, ${ }^{185}$ and their underlying policy has been declared to be strictly local, covering only property remaining within the jurisdiction. ${ }^{166}$ Accordingly, the validity of the bequest has been determined and the disposition given effect under the foreign law without regard to the situs and domiciliary prohibitions. ${ }^{107}$

Thus, in the leading case of Hope v. Brewer, ${ }^{168}$ a New York testator bequeathed property to a charity in Scotland under conditions that violated the New York statute against perpetuities. The court declared that the law of New York was inapplicable "to a gift in trust to be administered in Scotland, and perfectly valid there," and upheld the validity of the disposition under Scottish law, the law of the place where the trust was to take effect.

When the trust is valid under the law of the forum, situs, and the testator's domicile, the law of the foreign country where the bequest is to take effect need not be invoked. Tlus, a residuary trust settled by an Iowa testator for the benefit of the "poor of Voorst, Gelderland, Netherlands," was upheld under Iowa law. The validity of the disposition "necessarily depends on the law of the decedent's domicile and location of the property, rather than on the place of distribution," the Iowa court declared. ${ }^{180}$ And a New York Surrogate "assumed" that the laws of Germany, where a be-

165 Cf. Hope v. Brewer, 136 N.Y. 126, 139, 32 N.E. 558, 561 (1892). "Such laws are not generally regarded as limitations upon the power of the owner to transfer or transmit the property, but regulations applicable to the holding of property in the particular community, founded upon political or social considerations."; Equitable Trust Co. v. Ward, 29 Del. Ch. 206, 48 A.2d 519, (1946): "Ordinarily, the policy of any such general prohibitory statutory provision in the domiciliary state seems to be directed at the holding rather than the giving of the fund."

106 Cf. Hope v. Brewer, 136 N.Y. 126, 137-38, 32 N.E. 558, 561 (1892). "The law of this state inhibiting ... the suspension of the power of alienation of real estate, and the absolute ownership of personal property is founded upon a public policy of our own. Our law . . w was designed only to regulate the liolding of property under our laws and in our state, and a trust intended to take effect in another state, or in a foreign country, would not scen to be within either its letter or spirit." Kurzman v. Lowy, 23 Misc. 380, 383, 52 N.Y. Supp. 83, 85 (Sup. Ct. 1898). "Such property as shall remain within the state of New York must be subject to the laws against perpetuities and forbidden trusts, for the laws of this state in that respect are designed to operate upon all the property within its limits.... But the object of the law is satisfied if the property is to be removed from the jurisdiction of the state."

$107 \mathrm{Cf}$. Hope v. Brewer, 136 N.Y. 126, 140, 32 N.E. 558, 562 (1892). "If the legatee, whether a natural or artificial person, and whether he takes in his own right or in trust, is capable, by the law of his domicile, to take the legacy in the capacity and for the purposes for which it is given, and the bequest is in other respects valid, it will be sustained irrespective of the law of the testator's domicile." (Emphasis added).

Strict compliance with the domiciliary rule would result in invahidation of wills of residents and validation of wills of non-residents. By resorting to the law of the place where the trust is to take effect, the courts avoid this harsh result and confine invalidity to the exclusively domestic situation where situs of the personal property, domicile of the testator, and law of the place where the trust is to take effect, are within the forum jurisdiction.

168136 N.Y. 126, 32 N.E. 558 (1892).

160 Klumpert v. Vrieland, 142 Iowa 434, 121 N.W. 34 (1909). 
quest made by a New York domiciliary was to take effect, were the "same as prevail in this state," and held the trust to be valid "as being within section 12 of the personal property law." 170

One would, perhaps, expect that wills of nonresidents creating trusts prohibited by the law of the forum, situs, and place where the bequest is to take effect, should be declared invalid as violating the "strictly" local policy against accumulation of estates. ${ }^{171}$ In this group of cases, however, the courts have construed the forum law as regulating capacity to dispose rather than capacity to receive and have so narrowly delimited its applicability ${ }^{172}$ that it is generally held that wills of nonresidents which are valid according to the testator's domiciliary law will be given effect despite the violation of the situs and forum law and the invalidity of the trust under the law of the place where the bequest is to take effect. ${ }^{173}$

Thus, a bequest by a native and domiciliary of Peru to a New York charity, though invalid under the New York law prohibiting perpetuities, was upheld under the law of Peru. "There is no law that forbids gifts to charity by testators in other countries," the New York court said. "Our

170 Matter of Stephani, 164 Misc. 240, 300 N.Y. Supp. 813 (Surr. Ct. 1937). Similar bequests to foreign charities were upheld under the local law without reference to choice-of-law principles. See Morse v. First Nat. Bank, 194 S.W. 2d 578 (Texas Ct. of Civ. App. 1946) (bequest by Texan to the "poor of the Island of Jersey," England) ; Matter of Antoni, 186 Misc. 988, 61 N.Y.S.2d 349 (Surr. Ct. 1946) (bequest by New York domiciliary to the poor of a German village); Matter of Bell, 141 Misc. 720, 253 N.Y. Supp. 118 (Surr. Ct. 1931) (bequest by New York domiciliary to an Irish Church for the "Minister's salary"); Succession of Meunier, 52 La. Ann. 79, 26 So. 776 (1899) (bequest by Louisiana domiciliary to the poor of a Swiss municipality). Cf. In re Abbott's Will, 3 N.Y.2d 261, 165 N.Y.S.2d 63 (1957) (England); and companion cases In re Bishop's Will, 3 N.Y.2d 294, 165 N.E.S.2d 86 (1957) ; In re Perkins Will, 3 N.Y.2d 281, 165 N.Y.S.2d 77 (1957), involving bequests to nationalized English hospitals.

171 See note 166 supra.

172 Cf. Dammert v. Osborn, 140 N.Y. 30, 40-41, 35 N.E. 407, 410 (1893). "The policy that dictated our statutes against perpetuities and accumulations did not anticipate any danger from abroad, and our recent decisions are to the effect that they are local in their general scope and effect. . . . An accumulation to take effect in another country, or a bequest made there to take effect here, was not within the intention of the legislature when these statutes were framed...." Note 167 stepra.

${ }^{179}$ In addition to the cases discussed in the immediately following text see In re Grant's Estate, 200 Misc. 35, 101 N.Y.S.2d 423 (Surr. Ct. 1950) (bequest in favor of the testator's sister, though violating New York situs and domiciliary law of the testator, was upheld under Australian law-the law of the place where the trust was to take effect) ; Klumpert v. Vrieland, 142 Iowa 434, 121 N.W. 34 (1909); In re Stephani's Estate, 164 Misc. 240, 300 N.Y. Supp. 813 (Surr. Ct. 1937). But cf. In re Trotter's Estate, 175 Misc. 356, 23 N.Y.S.2d 1107 (Surr. Ct. 1940), where an appoimtment of personal property by an English donee, valid under the domiciliary English law, was declared invalid as violating the New York situs and donor's domiciliary law against perpetuities. "It is the established law of this state," the court said, "that the courts of New York alone must determine the validity and effect of an instrument, whether will or deed, which purports to exercise a power of appointment under the will of a New York donor." And, distinguishing Hope v. Brewer, note 168 supra, the court held that "That rule of law has never been extended to equitable or legal estates or remainders dependent upon the exercise under the power granted by a donor, resident in New York." 
statutes apply to domestic wills, that by their provisions are to be executed here."174 Similarly, certain testamentary trusts settled by a German domiciliary were "salvaged," partly under the law of Germany, and partly under the situs law of New York. ${ }^{175}$ And a bequest violating the New York statute against perpetuities was upheld under the testator's domiciliary law (Canada), though other provisions of the will were construed in the light of New York law in accordance with the testator's implied intention. ${ }^{176}$

(b) Unknown interests. It frequently happens that American citizens domiciled abroad create in their wills trusts and other interests unknown or forbidden by their domiciliary law. In such cases, application of the domiciliary rule would result in invalidation of wills perfectly valid under the American situs and forum law. The courts, in order to avoid this harsh result, resort to the situs law; and, to this effect, the device of finding a technical domicile within the situs jurisdiction, an appeal to the testator's intention that situs law be applied, and the presumption that the foreign domiciliary law is the same as that of the situs, are commonly employed techniques. ${ }^{177}$

In Cruger v. Phelps ${ }^{178}$ an American citizen who, with the exception of very short intervals, had spent his last forty years in France, executed on a visit to New York a will designed to dispose of real and personal property situated in that state. This will created interests unknown to the French law and was invalid in France though valid under the New York situs law. Had the court placed the emphasis on the testator's oral declarations that he intended "to live and die" in France and on certain of his acts manifesting that intention, the will would have failed with regard to the disposition of personal property which constituted the bulk of the estate. However, the court was quick to declare that "the will should be construed under the law of this state, as testator intended, where its general provisions are effective and valid," and found that the testator had not by his prolonged stay abroad relinquished his American domicile of origin. "A change of domicile to a foreign country," the court said, "is so injurious to the welfare of families, and affects so radically the validity and construction of testamentary acts ..." that "in cases of succession it requires plain and certain

174 Dammert v. Osborn, 140 N.Y. 30, 35 N.E. 407 (1893). See also Cross v. United States Trust Co., 131 N.Y. 330,30 N.E. 125 (1892) (interstate).

175 Matter of Lachenmeyer, 144 Misc. 678, 258 N.Y. Supp. 641 (Surr. Ct. 1928).

170 Matter of Grant-Suttie, 205 Misc. 640, 129 N.Y.S.2d 572 (Surr. Ct. 1954).

${ }^{177}$ See Equitable Trust Co. v. Ward, 29 Del. Ch. 206, 219, 48 A.2d 519, 526 (1946): "... [I]f a person creates a testamentary trust of personal property, to be held and administered in another state, where it is valid, the fact that its provisions are contrary to the general policy of the testator's domicile is usually unimportant in determining the validity of the gift and the conditions imposed."

17821 Misc. 252, 47 N.Y. Supp. 61 (Sup. Ct. 18997); cf. note 260 infra. 
evidence showing a fixed and definite purpose to establish that a person has become a foreigner to his native land." 179

Similarly, in the case of Matter of Tabbagh $h^{180}$ an American citizen domiciled in France, created by a will executed in that country a trust of movables for the benefit of his wife. Had the New York court determined the essential validity of the will under the law of the testator's domicile the disposition would have failed because testamentary trusts were illegal in France. But the court made reference to the testator's intention that his will be construed under the laws of New York and declared that "the construction and the validity of the will disposing of the deceased's assets in the United States are to be determined by the laws of this state."

The same rule was subsequently followed by the New York court on similar facts, the court stating that "the facts indicate deceased's intention to have New York law control the validity and effect of the testamentary dispositions." 181 Finally, a testamentary trust created by a German domiciliary for the benefit of German beneficiaries was upheld under New York law, the law of the forum and situs, the court "assuming" the laws of Germany to be in favor of the disposition. ${ }^{182}$

\section{Forced Heirship}

The law of forced heirship-that is, the legal rules granting certain dependents the right to participate in the distribution of the estate against the testator's express intention-necessarily represents a compromise between conflicting policies. The policies in favor of equal justice and fairness among the beneficiaries, protection of the family from pauperization, and indirectly, protection of the state from the obligation to support such pauperized families run counter to the policies underlying freedom of disposition and the protection of creditors. ${ }^{183}$ An evaluation and balancing of those conflicting policies results, in almost all legal systems, in limitations imposed upon a testator's freedom to dispose of his property; these vary from an almost unlimited freedom of testation to a practical abolition of testamentary succession. ${ }^{184}$

The adoption of choice-of-law rules with regard to cases involving sig-

$179 I d$. at 262,47 N.Y. Supp. at 68 . This despite the fact that the testator had purchased a burial vault in France.

180167 Misc. 156, 3 N.Y.S.2d 542 (Surr. Ct. 1938); cf. note 268 infra.

181 In re Stebbins-Vallois' Estate, 99 N.X.S.2d 402 (Surr. Ct. 1950). See also Matter of Vanneck, 158 Misc. 704, 286 N.Y. Supp. 489 (Surr. Ct. 1936) (Canada).

182 Stieglitz v. Attorney General, 91 Misc. 139, 154 N.X. Supp. 137 (Sup. Ct. 1915); cf. note 267 infra.

${ }^{183}$ See Scoles, Conflict of Laws and Nonbarrable Interests in Administration of Decedents Estates, 8 U. FLA. L. REv. 151, 156 (1955); Touster, Testamentary Freedom and Social Control-After-born Children, 6 Burrato L. Rev. 251, 258 (1957).

${ }^{184}$ See Dainow, The Early Sources of Forced Heirship; Its History in Texas and Lonisiana, LA. L. REv. 42 (1941). 
nificant foreign contacts depends on the forum's particular solution to the issue of forced heirship and on policies underlying its entire conflict of laws structure; among the latter are the protection of justified expectations, the recognition of a predominant interest in a foreign country, and the ease of determination of the applicable law. ${ }^{185}$

The Restatement of Confict of Lawes declares that "the right or other interest of the widow, child, or other person to a share of the movables of a decedent in preference to legatees is determined by the law of the state in which the decedent died domiciled." 186 This rule, which expressly includes the right to a "forced share" 187 against the provisions of the will, is according to the Restatement "a specific application" of the principle that "the domicile of the decedent is, in general, controlling in the distribution of his movable estate." 188

It is submitted that, at least with respect to cases involving international conflicts, the Restatement is not sustained by case authority; policy considerations militate against invariable determination of forced heirship claims according to the testator's domiciliary law; and the cases can be reconciled only on the grounds that (1) forced heirship of the surviving spouse is ordinarily governed by the law affording protection to that spouse, and (2) forced heirship of descendants is governed by the situs law validating the disposition in common law jurisdictions, and reducing it to the disposable portion in Louisiana.

The scarcity of authority in support of the domiciliary rule may be illustrated by the cases collected in two supplementary publications of the American Law Institute; the State Annotations, covering cases decided prior to the publication of the Restatement of Conflict of Laws, and the Restatement in the Courts, covering subsequent cases.

According to the State Annotations of Alabama, Florida, Illinois, Indi-

$185 \mathrm{Cf}$. Scoles, Conflict of Laws and Nonbarrable Interests in Administration of Decedents" Estates, 8 U. FLA. L. Rev. 151, 162 (1955).

188 Restatement, Confutct of Laws \$301 (1934). See Caeshure, Private InternaTTONAL LAW 532 (1952); DiceY, Conflict of LAWS 828 (1949); FaIConbridGe, Conflict or Laws 530 (1954); Goodrich, Conflict of Laws 513 (1949 ed.); Stumberg, Confutct of Laws 413 (1951); Westrake, Private Interatatjonat Law 156 (1912); Wharton, Conflict of LAWS 585 (1872). STORY, CoNfuTCT of LaWs (1st ed. 1834), does not discuss the problem.

187 Restateacent, Confutct of Laws \& 301 , comment $b$ (1934). The terms "forced heirship" and "legitime" describe the right given by civil law systems to certain classes of designated relatives to take agamst the will of a testator. Cf. BLACK, LAw Dictronary 1047 (1951 ed.). These terms are not used to describe the right of the surviving spouse, or child, to take against the will in common law jurisdictions. In New York, where the common law institutions have been abolished and the survivor has been given statutory rights very similar in nature to the civil law forced heirship, the term "election" has prevailed. It is arguable, therefore, that the Restatement which expressly mentions "forced share" was drafted to apply to both interstate and international conflicts.

188 RESTATEMENT, CoNFLiCT of LAwS \& 301, comment a (1934). 
ana, Kansas, Maryland, Michigan, Nebraska, New Hampshire, Oklahoma, Rhode Island, Tennessee, Texas, Virginia, West Virgnia, and Wisconsin, no cases were found in support of the rule either as to the forced heirship of the surviving spouse or that of the testator's descendants.

Several cases are cited in the State Annotations of California, Colorado, Louisiana, Massachusetts, Minnesota, Mississippi, Missouri, New York, Pennsylvania, South Dakota, and Washington, in support of the proposition that the rights of the surviving spouse are governed by the law of the testator's domicile at death. Only three involve international contacts. Of these, Barrett v. Heim ${ }^{189}$ involved intestate, and In re Pompal ${ }^{190}$ testamen tary succession. In both, the domicile of the deceased and the situs of the personal property were in the same jurisdiction, Minnesota, and the matter in issue was the applicability of local law for the protection of non-resident widows of resident deceased husbands. In both cases it was held that the widow was protected. In the third, Matter of Thorold, ${ }^{191}$ there was a dictum to the effect that the rights of the survivor were governed by the law of the testator's domicile. All that the case held was that a hearing should be granted for the determination of the domiciliary state since the survivor contended that, in spite of express declarations in the will to the contrary, deceased died domiciled within the situs and forum state. Thus, the actual holding of none of the international cases sustains the domiciliary rule.

Nor do the interstate cases support the domiciliary rule. Ten of them involved intestate succession. ${ }^{102}$ Among those involving testamentary succession, in eight instances situs of the personal property and domicile of the deceased were within the forum jurisdiction; ${ }^{193}$ two cases clearly involved succession to lands ${ }^{194}$ two simply held that widows of non-residents were not afforded protection under the situs and forum law; ${ }^{195}$ in another

180152 Minn. 147, 188 N.W. 207 (1922).

180150 Wash. 242, 272 Pac. 980 (1928).

101147 Misc. 899, 265 N.Y. Supp. 39 (Surr. Ct. 1933).

182 Connor's Widow v. Administrators, 10 La. Ann. 440 (1855); Foster v. Ferguson, 1 La. Ann. 262 (1846); Dunbar v. Dunbar, 5 La. Ann. 158 (1850); In re Lavenberg's Estate, 104 Wash. 515, 177 Pac. 328 (1918); Richardson v. Lewis, 21 Mo. App. 531 (1886); Matter of Bleicher, 142 Misc. 549, 255 N.Y. Supp. 368 (Surr. Ct. 1931); Lines v. Iines, 142 Pa. 149, 21 Atl. 809 (1891) ; Northwestern Masonic Aid Ass'n v. Jones, 154 Pa. 99, 26 Atl. 263 (1893); Stromberg v. Stromberg, 119 Minn. 325, 138 N.W. 428 (1912).

103 Blatt v. Blatt, 79 Colo. 57, 243 Pac. 1099 (1926); Matter of Harris, 150 Misc. 758, 271 N.Y. Supp. 464 (Surr. Ct. 1934) ; Matter of Brown, 133 Misc. 457, 233 N.Y.S. 145 (Surr. Ct. 1929) ; Hairston v. Hairston, 27 Misc. 704, 61 Am. Dec. 530 (1854) ; Ishain Austin's Estate, 73 Mo. App. 61 (1898) ; Estate of Myers, 115 Cal. App. 443, 1 P.2d 1013 (1931) ; Mallory's Estate, 300 Pa. 217, 150 Atl. 606 (1930); Matter of Cutler, 114 Misc. 203, 186 N.X. Supp. 271 (Surr. Ct. 1921).

194 Cheney v. Cheney, 214 Mass. 580, 101 N.E. 1091 (1913) ; Norris v. Lloyd, 183 Iowa 1056, 168 N.W. 557 (1918).

185 Slaughter v. Garland, 40 Misc. 172 (1866); In re Babcock's Estate, 64 S.D. 283, 266 N.W. 420 (1936). 
two, the court resorted to the law of the marital domicile; ${ }^{100}$ and finally, one case involved the distinct problem of revocation by subsequent marriage. ${ }^{107}$

Only six cases are cited in the State Annotations which concern forced heirship of descendants. In the first, Estate of Baubichon, ${ }^{108}$ forum, situs, and domicile were in California, and full effect was given to the testator's intention under the law of that state. In the second, In re Lewis's Estate, ${ }^{100}$ and third, Succession of Harris, ${ }^{200}$ Louisiana law was applied in the succession of foreign domiciliaries following a characterization of the property in question as "incorporeal immovable." The fourth, Matter of Marsland, ${ }^{201}$ applied New York situs law in the succession of a Swiss domiciliary on a power of appointment theory. ${ }^{202}$ Thus, only in the fifth and sixth, Trimble v. Dzieduzyikit ${ }^{203}$ and In re Cruger, ${ }^{204}$ was a foreign domiciliary law applied; both are distinguishable on their facts.

Of these, Trimble v. Dzieduzyiki-the only authority relied on by Professor Beale for the proposition that the law of the domicile of the testator determines "whether there is a forced heirship"205 - testatrix died domiciled in Italy and left her entire estate, consisting partly of a trust fund in New York over which she had a power of appointment, to her husband. The will was admitted to probate in Italy, but the disposition, which infringed on a minor child's legitime, was reduced to the disposable portion according to the Italian law. In a proceeding for a judicial settlement in New York, seat of ancillary administration, the court ordered that the assets be remitted to the domiciliary executor for distribution according to the law of the domicile of testatrix. For several reasons the value of this case as a precedent is questionable. First, there was an amicable settlement rather than an adversary proceeding since the husband of testatrix had freely relinquished all his claims in excess of the disposable portion under the law of Italy. Second, the case involved recognition of a foreign judgment rather than a problem of choice-of-law. ${ }^{206}$ Third, distribution was

106 Hageman v. Fox, 31 Barb. 475 (N.Y.1860); Flatauer v. Loser, 156 App. Div. 591, 141 N.Y. Supp. 951 (1st Dep't 1913).

107 In re Braithwaite, 19 Abb. N.C. 113 (N.Y. 1887).

19849 Cal. 18 (1874). Testator, a French citizen, left his entire estate situated in California to his American mistress to the prejudice of his children who, under French law, were entitled to a forced share. The court found that the testator had died domiciled in California and upheld the disposition not only disregarding the law of France but also an antenuptial agreement which limited the testator's power to dispose of more than one third of his estate. $C f$. text following note 228 infra.

10932 La. Ann. 385 (1880).

200179 La. 954, 155 So. 446 (1934). See text at note 250 infra.

201142 Misc. 230, 254 N.X. Supp. 293 (Surr. Ct. 1931).

202 Cf. text at notes 266, 304 infra.

20357 How. Pr. 208 (N.Y. 1878).

20436 Misc. 477,73 N.Y. Supp. 812 (Surr. Ct. 1901).

2052 Beate, Conflict of LaWs 1036 (1935).

206 See text at note 4 supra. 
not locally made but the assets were remitted to the domiciliary executor. Fourth, subsequent decisions have consistently applied the law of the donor's domicile in cases of succession to personal property subject to a power of appointment; and the decision in Matter of Marsland, supra, is directly to the contrary. ${ }^{207}$ And finally, the case may be regarded as confined to its own facts by the recent decision in Matter of Cook. ${ }^{208}$

Nor is the other, In re Cruger, conclusive as a precedent. In that case, the testator, an American citizen, died in France. By a proper will executed in the holographic form in France deceased left to his French mistress his entire estate consisting of personal property situated in New York. Children of the testator by a former marriage residing in New York contested the disposition on several grounds, among them (1) total invalidity of the disposition if the law of New York governed succession and (2) partial invalidity, in so far as they were deprived of their rights to a forced share, if the law of France governed. The court chose the alternative better conforming with the testator's intention and upheld the disposition in so far as this was warranted by the law of France. Separate determination of the issue of formal validity under the law of France, the law of the place of execution, and of the issue of forced heirship under the law of New York, the alleged domicile at death, was impossible at that time because the New York statute referred the issue of formal validity of wills of residents exclusively to the law of New York and under that law the instrument was null and void. The court observing that "the propounded paper ... can be sustained, if at all, only as a French will, executed in France by a resident of that country," proceeded to find that the testator was domiciled in France. ${ }^{209}$ But ordering that the will be carried into effect, the court felt restrained "to grant to the beneficiary named in it no greater rights than the law of France, to which it [the will] owes all of its force that it has, gives to it." 210

If we may rely on the Restatement in the Courts, not a single court has followed the Restatement in the determination of forced heirship rights of descendants; and in the determination of forced heirship rights of the surviving spouse the pertinent section was cited only twice since its publication in 1934-both times in interstate cases. In the first of these an inter

207 See Matter of Marsland, 142 Misc. 230, 254 N.Y. Supp. 293 (Surr. Ct. 1931).

208204 Misc. 704, 123 N.X.S.2d 568 (Surr. Ct. 1953), aff'd, 283 App. Div. 1047, 131 N.Y.S.2d 882 (1st Dep't 1954).

209 Cf. text at note 260 infra.

210 A court today would not be confronted with such a dilemma since, with respect to the formal validity of wills, alternative reference is made to the law of the place of execution for both residents and non-residents. Thus, the issue of formal validity would be independently considered, and most probably, the issue of forced leirship would be adjudicated in favor of the will under the situs law. See text at note 87 supra; text at note 258 infra. 
vivos trust was upheld under the situs law; ${ }^{211}$ in the second, a non-resident widow was not permitted to recover against the will under the situs law. ${ }^{212}$

The conspicuous scarcity of cases applying foreign domiciliary law, ${ }^{213}$ may be contrasted with numerous decisions in which the issue of forced heirship of the surviving spouse and of the descendants of the testator, was determined according to policy considerations rather than "logical" postulates.

(a) The Surviving Spouse. Domestic laws in both civil law countries and common law jurisdictions afford protection to the surviving spouse against the express intention of the testator. Provisions which preserve some portion of a decedent's estate to the surviving spouse are found in some form in all states; ${ }^{214}$ these vary from the old common law institution of dower and curtesy ${ }^{215}$ to the idea of a forced portion. ${ }^{216}$ Moreover, the common law doctrine of implied revocation of the will by subsequent marriage, prohitions against charitable bequests, and the institution of community property give expression to the same policy-protection of the survivor from undeserving pauperization. Because of this similarity of domestic laws and policies the conflict in multiple-contact cases of succession is one of degree

211 National Shawmut Bank v. Cumming, 325 Mass. 457, 91 N.E.2d 337 (1950).

212 In re Sahadi's Estate, 125 N.Y.S.2d 204 (Surr. Ct. 1953).

213 The only recent case applying a restrictive domiciliary law was Estate of Russel, 159 N.Y.S.2d (Surr. Ct. 1956) (actually involving a United States'-and not a child's interest).

214 See Kunn, Comparattve Comementartes on Private Internationat Law 333 (1937); Rinensstend, Cases on Decedents' Estates 62 (2d ed. 1955); Breslauer, Conflict of Laws in Restriction of Freedom of Testation, 27 Iowa L. Rev. 425 (1942); Bordwell, Statute Law of Wills, 14 IOWA L. REV. 1 (1928); Scoles, Confict of Laws and Nonbarrable Interests in Administration of Decedents' Estates, 8 U. FIA. L. REv. 151 (1955); Conflict of Laws and Elections in Administration of Decedents Estates, 30 IND. L. J. 293 (1955); BEECHERR, ELEcTIONS Agansst WrIs (1940); Haskins, Homestead Exemptions, 63 HARv. L. REv. 1289 (1950); Laube, Right of a Testator to Pauperize His Helpless Dependents, 13 CoRs. L.Q. 55 (1928); Opton, Recognition of Foreign Heirship and Succession Rights to Personal Property in America, 19 GEO. WASE. L. REv. 156 (1950); Laufer, Flexible Restraints on Testamentary Freedom, 69 HARv. L. REv. 227 (1955); Cahn, Restraints on Disinheritance, 85 U. PA. L. REv. 139 (1936); McMurray, Liberty of Testation and Some Modern Linitation Thereon, 14 Irr. L. REv. 96 Notes, 22 A.L.R. 437 (19923); 88 A.I.R. 861 (1934); 105 A.L.R. 271 (1936); Restriction on Testation in Kentucky, Common Law and Statutory with a suggested plan of legislation, $46 \mathrm{Kr}$. L.J. 133 (1957).

${ }^{215}$ See e.g. ArA. Code tit. 34, $\$ 40$ (1940); ARK. Stat. tit. 61, $\$ 201$ (1947); Dex. Code ANv. tit. 12, § 901 (1953); Ga. Code tit. 536, § 101 (1933); Irx. REv. STat. Ch. 3, \& 170 (SmithHurd 1953); Iowa CoDe tit. 636, $\$ 4$ (1954). See Breslauer, Conflict of Laws in Restriction of Freedom of Testation, 27 IOWA L. Rev. 425, 426 n.4 (1942); Bordwell, Statute Law of Wills, 14 IowA L. REv. 172, 191 (1929).

${ }^{216}$ See Breslauer, Conflict of Laws in Restriction of Freedom of Testation, 27 Iowa $L$. REv. $425,426 \mathrm{n} .12$ (1942). In these jurisdictions where the system of community property prevails, dissolution of the marriage by death results in the immediate acquisition by the survivor of an undivided half in the community property and no adverse testatmentary disposition can deprive him from a share in the community fund. See RHEINSTERN, CASES on DECEDENTS' EsTATES 62 (2d ed. 1955). 
of protection in both the interstate and the international level; and the applicability of a foreign domiciliary law in such cases does not ordinarily conflict with the forum policy.

The Restatement of Confict of Laws, we have seen, suggests invariable determination of the issue of forced heirship of the surviving spouse according to the law of the testator's domicile at death. But, while domiciliary law was applied in some cases, the Restatement rule is contradicted by what is perhaps the majority of the decisions; these have applied either situs law ${ }^{217}$ or the law of the last common domicile of the spouses. ${ }^{218}$

It may be that it is too early to speak of a common law choice-of-law rule in this field since the law making process is still in full swing. The seemingly contradictory international cases, however, can be reconciled on the ground that the right of the surviving spouse to a forced share is governed by the law that would afford protection rather than the law that would uphold the disposition. To this effect, claims by the surviving spouse against the will have been classified as involving (1) succession and (2) marital property. ${ }^{219}$

Whenever the issue is characterized as a matter of succession, the survivor may be afforded protection either under the situs and forum law or that of the domicile of the deceased. More frequently in cases involving interstate than international contacts, the surviving spouse seeks protection under the situs and forum law. Several state statutes cover only resident survivors of resident deceased spouses; ${ }^{220}$ others extend their protection to non-resident survivors of resident or even non-resident testators. ${ }^{221}$ Ordinarily, the courts are inclined to afford protection under their forum and situs law, ${ }^{222}$ although decisions adopting a narrow delimitation of local

217 See text at note 220 infra.

218 See text at notes 226,229 infrra.

219 See text following note 228 infra. But cf. Marse, Martral Property iv Confeitcr of LAws 732 (1951), arguing that "the claim of a surviving spouse for an nonbarrable share in the common law states has heen invariably characterized as an issue of succession for choice. of-law purposes." See also Delaume, Marital Property and American-French Conflict of Laws, 4 Arr. J. Cosrp. L. 35 (1955); Goodrich, Matrimonial Domicile, 27 YaIE L.J. 49 (1917); Harding, Matrinonial Domicile and Marital Rights in Movables, 30 MTCH. L. REv. 859 (1932); Leflar, Community Property and the Conflict of Laws, 21 CAcIF. L. REv. 221 (1953). 220 See Scoles, Confict of Lazes and Nonbarrable Interests in Administration of Decedents' Estates, 8 U. FLA. L. REv. 151, 173 (1955).

221 See In re Smith's Estate, 48 N.Y.S.2d 641 (Surr. Ct. 1944); In re McCombs' Estate, 80 N.E.2d 573 (Ohio Prob. 1948).

222 In re Gould's Estate, 140 N.E.2d 793 (Ohio Prob. 1956), affd, 140 N.E.2d 801 (1956) (granting to the non-resident survivor the right to elect under the statutes of Ohio as to personal property situated in that state, although under the law of deceased's domicile, British Bermuda, the surviving spouse had no such right); In re Gallagher's Estate, 169 N.Y.S.2d 271 (Surr. Ct. 1957) ; Darrow v. Füth Third Union Trust Co., 139 N.E.2d 112 (Com. Pl. Ohio 1954) ; Palmer v. Crews, 203 Miss. 806, 35 So.2d 430 (1948); Boeing v. Owsley's, 122 Minn. 190, 142 N.W. 129 (1913); Bolton v. Barnett, 131 Miss. 802, 95 So. 721 (1923) (interstate cases); cf. notes 224,225 infra. 
law may be found. ${ }^{223}$ Thus, non-resident widows of resident testators were afforded protection under the situs, forum, and domiciliary law in two international cases, ${ }^{224}$ and in another, ${ }^{225}$ the non-resident widow of a testator domiciled in Spain was afforded protection under the New York situs law. On the other hand, invocation of a foreign domiciliary law affording protection to the survivor is quite common in cases involving international contacts. But here, unlike the determination of other issues of essential validity where the foreign law is disregarded and the disposition is carried into effect under the situs law, the courts ordinarily apply foreign restrictive law and reduce the disposition to the disposable portion. ${ }^{226}$

Quite frequently, the surviving spouse is afforded protection under a law other than that of the situs or of the domicile of the testator at death following a characterization of the issue as a matter of marital property. In this respect, two lines of decisions are distingnishable: those based on antenuptial agreements, and those based on the law of the matrimonial domicile. Two cases, Crosby v. Berger ${ }^{227}$ and Strebler v. Wolf, , $^{228}$ are examples of the former. In both, non-resident survivors of resident testators were awarded estates of personal property situated in New York according to the terms of antenuptial contracts entered into and valid in France. On the other hand, resort to the law of the matrimonial domicile has been made in several cases. Thus, the non-resident widow of a testator who died in a lunatic asylum in Pennsylvania was awarded in New Jersey one-half

${ }^{223}$ See, e.g., Matter of Slade, 154 Misc. 275, 276 N.Y. Supp. 956 (Surr. Ct. 1935). The court, however, pointed out that "the disparity between the benefits under the will and the amount of one-half of the net estate is relatively small, but the payment to her of the difference between such benefits and her statutory share would diminish the interest of other legatees and particularly those of certain infants named as beneficiaries in the will." See also Potter v. Titcomb, 22 Me. 300 (1843) (St. Croix, West Indies).

224 In re Weiss' Will, 64 N.Y.S.2d 331 (Surr. Ct. 1946). (England); In re Pompal, 150 Wash. 242, 272 Pac. 980 (1928) (Canada). See Barrett v. Heim, 152 Minn. 147, 188 N.W. 207 (1922); Wood v. Wood, 5 Paige 596 (N.Y. Ch. 1836).

225 In re Smith's Estate, 48 N.Y.S.2d 631 (Surr. Ct. 1944). See Hutchison v. Ross, 262 N.Y. 381,187 N.E. 65 (1933) (validity of inter-vivos trust).

${ }^{226}$ Schultz v. Dambmann, 3 Bradf.Surr. 379 (N.Y. 1855). See also Matter of Thorold, 147 Misc. 899, 265 N.Y. Supp. 39 (Surr. Ct. 1933) (England); Matter of Moran, 180 Misc. 469 , 39 N.Y.S.2d 929 (Surr. Ct. 1943). For interstate cases to the same effect see Bolling v. Bolling, 88 Va. 524, 14 S.E. 67 (1891) (lands) ; Staigg v. Atkinson, 114 Mass. 564, 12 N.E. 354 (1887) (lands) ; Flatauer v. Loser, 156 App. Div. 591, 141 N.Y. Supp. 951 (1st Dep't 1913); Hegeman v. Fox, 31 Barb. 475 (N.Y. 1860).

2273 Ed. Ch. 538 (N.Y. 1842).

228152 Misc. 859, 273 N.Y. Supp. 653 (Sup. Ct. 1934). For other international cases involving antenuptial contracts see Decouche v. Savetier, 3 Johns. Ch. 190 (N.Y.1817) (intestacy); De Barrante v. Gott, 6 Barb. 492 (N.Y. 1849) (intestacy); Kleb v. Kleb, 70 N.J. Eq. 305, 62 Atl. 396 (1905) (lands); Fuss v. Fuss, 24 Misc. 256 (1869) (lands); Roth v. Roth, 104 III. 35 (1882) (lands); Ordronaux v. Rey, 2 Sandf. Ch. 33 (N.Y. 1844) (lands). Forced heirship claims of descendants according to the terms of antenuptial agreement were denied In re Estate of Baubichon, 49 Cal. 18 (1874); Long v. Hess, 154 IIl. 482, 40 N.E. 335 (1895) (lands). 
of the estate according to the law of France; ${ }^{229}$ the non-resident widow of a non-resident testator recovered one-half of the estate situated in New York under the law of $\mathrm{Cuba}^{230}$ and the non-resident widow of a resident testator was allowed to recover part of the estate in New York on the ground that the law of the matrimomal domicile (localized in France, the place of the celebration of the marriage, the domicile of the widow, and apparently the last common domicile of the spouses) gave rise to an "implied contract" limiting deceased's power of disposition. ${ }^{231}$

(b) The Descendants of the Testator. Civil law and common law, in spite of historical, structural, and procedural differences, and though premises, rules, and methods of legal thinking differ, give in most instances strikingly similar solutions to the problems of everyday life; but in the field of forced heirship for the benefit of a testator's descendants, ${ }^{232}$ the two systems take almost diametrically opposite positions and compete sharply in jurisdictions in which they meet. ${ }^{233}$

Civil law has developed an elaborate system of forced heirship, a venerable institution of a social environment offering fewer opportunities for individual economic development. ${ }^{234}$ In the American common law, on the

220 Harral v. Wallis, 37 N.J. Eq. 458 (1883), aff'd sub nom. Harral v. Harral, 39 N.J. Eq. 279 (1884).

230 In re Mesa's Estate, 159 N.Y. Supp. 59 (1916).

231 Bonati v. Welsch, 24 N.Y. 157 (1861). See also Succession of McKenna, $23 \mathrm{La}$. Ann. 369 (1871); Gale v. Davis, 4 Martin. 645 (La. 1817). Strebler v. Wolf, 152 Misc. 859, 273 N.Y. Supp. 653 (Sup. Ct. 1934) ("the law of matrimonial domicile, which is in France, will govern"). But cf. Matter of James, 221 N.Y. 242, 116 N.E. 1010 (1917) (widow amply provided for in the will, estopped from claiming community property rights under the law of matrimomial domicile); Matter of Dumarest, 146 Misc. 442, 262 N.Y. Supp. 450 (Surr. Ct. 1933 (no commurity property between decedent and his non-resident and divorced widow; foreign law presumed to be identical with that of the forum).

232 Forced heirship of descendants, unlike that of the surviving spouse, involves almost exclusively international conflicts. In this respect, the present study based on all the reported cases in the United States, purports to be complete in itself.

233 This competition is apparent in the legal systems of Louisiana, Texas, Quebec, Scotland, South Africa, and Ceylon, where the civil law principle of forced heirship came into contact with the common law principle of freedom of disposition. With the exception of Louisiana, where forced heirship was given constitutional sanctification and protection, LA. Consr. art. IV, $\$ 16$ (1921), and Scotland, freedon of disposition has prevailed over forced heirship of descendants. See with respect to Louisiana and Texas: Dainow, The Early Sources of Forced Heirsizip; Its History in Texas and Louisiana, 4 LA. L. REv. 42 (1941). Scotland: GLOAO, INTRODUCTION to THE LAW OF Scotrand 480 (2d ed. 1933); Dainow, Limitations on Testamentary Freedom in England, 25 CoRs. L. Q. 337, 344 n. 44 (1940). Quebec: Dainow, Unrestricted Testation in Quebec, 10 TUL. L. Rev. 401 (1936). South Africa: LEE, AN INTROduction to Roman-Dutch Law (5th ed. 1953); Natham, The Comaron Law of South Africa 1848, 1860 (1906). Ceylon: LEE, op cit. supra.

234 The interrelation of social environment and inheritance laws has been demonstrated by Borssonade, Histome de ia Reserve Hereditaire et de son Infeuence Morale et EconoIrRQUE (1873). See also Nussbaum, Liberty of Testation, 23 A.B.A.J. 183 (1937); MAX WeBER, Law IN Econosry and Society 137 (Rheinstein's transl. 1954); Morel, La Liberté Testamentouire et la Situation Social, 8 TrEans 77 (1957); Touster, Testamentary Freedom and Social Control of After-born Children, 6 BuFsaIo L. REv. 251, 255-59 (1957). 
other hand, freedom of disposition has been given paramount consideration. ${ }^{235}$

The laws of the several states of the United States, with the sole exception of Louisiana, do not directly restrict freedom of disposition in favor of the testator's descendants. ${ }^{236}$ Some degree of protection is afforded only indirectly by certain devices developed by the common law such as negative disinheritance, ${ }^{237}$ after-born and pretermitted heir statutes, ${ }^{238}$ and statutes limiting a testator's freedom to leave more than a defined portion of his estate to charities if he either is survived by close relatives, or attempts to make the charitable bequest during a specified period of time before death. ${ }^{239}$ The distinguishing feature of this common law system is that the testamentary scheme is disturbed only in so far as this is warranted by changed objective circumstances, in accordance with the testator's presumed intention. ${ }^{240}$

In contrast to this system prevailing in common law jurisdictions, in civil law countries testamentary freedom is limited directly and against the testator's express intention by securing to his descendants and other close relatives a "legitime" or "forced share" in the estate. ${ }^{241}$ The nature and essential characteristics of this civil law institution and the measure of pro-

235 See Touster, supra note 234, at 255 ff. Cf. In re Good's Estate, 274 S.W.2d 900 (Tex. Civ. App. 1955): "A citizen of this state may by his will dispose of his property without regard to the ties of nature and relationship, and may do so in defiance of its rules of justice or the dictates of reason"; McWilliams v. McWilliams, 140 N.E.2d 80 (Com. Pl. Ohio 1956): "We believe that a person having the absolute title to money or personal property has the right to dispose of it as he wishes, either during his lifetime, or at deatly through proper testamentary disposition"; note 383 infra.

236 See Rheinstemi, Cases on Decedents' Estates 58, 80 (2d ed. 1955) ; Bordwell, Statute Lave of Wills, 14 Iowa I. REv. 172, 194 (1929); Oainow, The Early Sources of Forced Heirship; Its History in Texas and Louisiane, 4 LA. L. Rev. 42, 57 (1941); Laufer, Flexible Restraints on Testamentary Freedom, 69 HaRv. L. Rev. 277, 278 (1955).

237 See Rheinstedn, Cases on Decedents' Estates 80 (2d ed. 1955).

238 See e.g., ME. Rev. Stat. tit. 169, § 9 (1954); Mass. Laws ANN. c. 101, § 20 (1951); N.D. Rev. CoDe tit. 56, $\$ 0417$ (1943), and see Mathews, Pretermitted Heirs: An Analysis of Statutes, 29 ColuM. L. REv. 748 (1957). Such statutes have even been interpreted "as a technique for reinforcing or preserving testamentary freedom," see Touster, Testamentary Freedom and Social Control of After-born Children, 6 BufFalo L. REv. 251, 255 (1957).

239 See e.g., GA. Code tit. 113, \& 107 (1935); Idaro Code ANN. tit. 14, § 326 (1949); IowA Code tit. 633, §3 (1954); Mont. Rev. Codes tit. 91, §142 (1947); PA. Ann. Stat. tit. 20, $\S 195$ (Purdon 1953).

240 See Breslauer, Confict of Laws in Restriction on Freedom of Testation, 27 Iowa L. Rev. 425, 439 (1942); Bordwell, Statute Law of Wills, 27 Iowa L. Rev. 172, 174-77 (1929); Dainow, Inheritance by Pretermitted Children, 32 InL. L. Rev. 1 (1937). Cf. Laufer, Flexible Restraints on Testamentary Freedom, 69 HaRv. L. Rev. 277, 291, 295 (1955).

241 See, e.g., Cubc: C.C. art. 808 (1888). France: C.C. art. 913-19 (1803), amended by laws of March 25, 1896, and March 24, 1898. Germany: B.G.B. art. 2303-38 (1896). Greece: C.C. art. 1825-45 (1940). Italy: C.C. art. 536 (1942). Scotland: Hog v. Lashley, 6 Bro.P.C. 577 (1792). 
tection afforded to the descendants ${ }^{242}$ of a liberal testator are exemplified in the United States by the provisions of the Louisiana Civil Code of $1870 .^{243}$

This sharp conflict of domestic policies is peculiar to the field of forced heirship of descendants. ${ }^{24}$ Thus, even if testamentary succession were "generally" governed by the law of the testator's domicile, it would not necessarily follow that forced heirship of descendants should be subjected to the same law. Such a rule, far from being a "specific application" of the "general" principle as the Restatement declares, would conflict with superior policies of the forum, be it Louisiana, the only civil law state in the Union, or a common law jurisdiction.

The policy underlying the forced heirship provisions of a civil law forum, primarily enacted for the protection of resident dependents, ${ }^{245}$ seems to require that forum and situs law be applied without regard to the domicile of the testator whenever residents are deprived of their rights to a forced share. Thus, in Louisiana residents are generally afforded protection in the distribution of local assets notwithstanding a contrary domiciliary law of the testator; and sometimes this protection is extended to non-

242 Technically, the surviving spouse is not a forced heir in Louisiana, but she or he is amply provided for in other ways. There is an indefeasible right to one half of the community property (LA. C.C. of 1870 art. 2406), the needy spouse's marital portion of one fourth of a rich estate (art. 2382), and the widow's privileged claim to one thousand dollars from an insolvent estate (art. 3252).

243 In Louisiana, as in both French and German Law, excessive dispositions are not null, but reducible to the disposable portion. LA. C.C. of 1870 art. 1502 et. seq.; Succession of Moore, $40 \mathrm{La}$. Ann. 531, 4 So. 460 (1888). The child's cause of action for the reduction of excessive dispositions arises after the death of the parent and is subject to a five year's period of limitation. art. 1502 et seq.; art. 3542 et seq. This right is personal to the forced heir or lis heirs and assignees; creditors cannot exercise it. art. 1504. Forced heirs nay be deprived of their legitime by a judicial decision of unworthiness to inherit for recognized reason, art. 964 et seq., and by a formal exercise of the power of disinheritance in the will of the testator; such disinheritance must be express, nominatim, and for some of the specifically enumerated "just causes," sufficiently proved after the death of the testator. art. 1617 et seq. Disinheritance is not favored, and release of inheritance agreements do not bind the forced heir. Succession of Reems, $134 \mathrm{La}$. 1034, 64 So. 898 (1914); Hoggatt v. Gibbs, 12 La. Ann. 770 (1857).

244 Those differences in domestic legislation are accentuated by a conflict of conflict of laws rules, since in most continental countries succession is referred to the national law of the deceased. See Batiffor, Droit International Prive, 669 (1949); Nussbaun, Deutches Internationates Privatrecht 352 (1932); Wolff, Private International Law 586 (1945).

245 Cf. 2 Pillet, Droit International Prtve 384 (1924); 4 Frankenstein, Internationates Privatrecht 399 (1935); Scoles, Conflict of Laws and Nonbarrable Interests in Administration of Decedents Estates, 8 U. FIA. L. REv. 151, 173 (1955). This protection of residents is extended in Louisiana not only against the testator's will but also against the operation of foreign law governing intestacy. In Marcenaro v. Mordella, 10 La. Ann. 772 (1855), deceased died in Gibraltar, her domicile, leaving personal property in Louisiana. She was survived by two children domiciled in Louisiana and lier husband domiciled in Gibraltar. Intestate's husband brought action in Louisiana to recover his wife's personal property claiming that under the law of deceased's domicile he was entitled to "reduce to possession" her entire personal estate. The 
resident descendants of non-resident testators. ${ }^{246}$ Characterization of the inheritance right as "incorporeal immovable," public policy, ${ }^{248}$ and a realistic recognition that forced heirship is governed by the situs law, ${ }^{240}$ are resorted to as a means of imposing reasonable limits on the freedom of both resident and non-resident testators to dispose of local property to the prejudice of their descendants.

Three cases are illustrative: (1) In Succession of Harris, ${ }^{250}$ testatrix died in Alabama, her domicile. She left real and personal property in that state and a chose in action in Louisiana-a claim to a forced share in the estate of her predeceased son, a resident of Louisiana. Her will, executed and valid in Alabama, was contested by forced heirs in Louisiana on the ground that it infringed on their legitime. The court, in order to protect these heirs, characterized the Louisiana assets as "incorporeal immovable" and, over the contention of the Alabama executor that distribution should be made according to the will, the disposition was reduced to the disposable

court refused to apply domiciliary law on the ground that a right is not enforcible "where it is against the settled policy of that country, and defeats the rights of any of her citizens, particularly as to an interest so carefully guarded as that of 'legitine'," and held the Louisiana law applicable on the ground that the right to succession "whether considered a legal right or a choice in action at common law lias its domicile in Louisiana."

246 See, e.g., Caballero v. the Executor, 24 La. Ann. 573 (1872), discussed in text following note 254 infra; Succession of Taylor, 28 La. Ann. 367 (1876), discussed in text following note 251 infra.

247 Succession of Harris, 179 La. 954, 155 So. 446 (1934). See Marcenaro v. Mordella, 10 La. Ann. 772 (1855) ("The right to succession is considered a real right in Louisiana").

248 See Marcenaro v. Mordella, 10 La. Ann. 772 (1855) ("Enforcement of plaintiff's right would be against the settled policy of Louisiana and in prejudice of the forced heirs, Louisiana domiciliaries"), quoted with approval in Succession of Harris, 179 La. 954, 155 So. 446 (1934).

$240 \mathrm{Cf}$. note 247 supra. The domicile of the testator has never been a predominant connecting factor in Louisiana. See Succession of Gaines, 45 La. Ann. 1237, 1245, 14 So. 233, 236 (1893). "The domicile of a testator, as to the form and effect of a will, is ignored by our law. It is the place where it is made, and the property disposed of where situated that is recognized." Following continental tradition, the law of the place of execution was early resorted to as an alternative point of reference with regard to the formal validity of wills. See Jones v. Hunter, 6 Rob. 235 (La. 1843); art. 1596 of the Crvn CoDe of 1870; art. 1589 of the Crvis CODE of 1825; art. 109 of the CrvIn CODE of 1808. In Succession of Senac, 2 Rob. 258 (La. 1842), a will valid under the law of the testator's domicile at death, France, was beld invalid in Louisiana, the place of execution and situs of the personal property, on the ground that the law of the place of execution governed the vahdity of the disposition. The law of the testator's domicile was thus supposed to govern the validity of wills of inovables only when the instrument was executed outside the state and the deceased lad never acquired a domicile in Louisiana. See C.C. 1870 art. 10; Succession of Packwood, 9 Rob. 438 (La. 1845); Estate of Lewis, 32 La. Ann. 385 (1880); Note, 14 TULANE L. REv. 313 (1940). And for a case involving application of situs law to the construction of the will of a non-resident, see Penny v. Christmas, 7 Rob. 481 (La. 1844).

250179 La. 954, 155 So. 446 (1934). The court relied Jieavily on Marcenaro v. Mordella, note 234 supra. See also Estate of Lewis, 32 La. Ann. 385 (1880); Succession of Senac, 2 Rob. 258 ( $\mathrm{La} .1842)$. 
portion according to Louisiana situs law. (2) In Succession of Taylor, testator died domiciled in Kentucky leaving assets in Kentucky, Ohio, and Louisiana. A will, executed in Kentucky, was probated in Louisiana by the public administrator; but the will "was entirely ignored," and two alleged children succeeded in obtaining orders to be put in possession of two-thirds of the estate as heirs-at-law. The Kentucky (domiciliary) executor brought suit for an accounting against these heirs-at-law and the public administrator in Louisiana and prayed that the will be carried into effect. He proved at the trial that the alleged heirs were illegitimate with no inheritance rights under either the law of Kentucky, their father's domicile, or Ohio, their own domicile. The court held that the children were entitled to a share in the estate-a result which, though explainable on grounds of "charity, one of the noblest Christian virtues"252 and perhaps consistent with the general forum policy, could be hardly sustained by the positive law of Louisiana under the facts of that case. ${ }^{253}$ (3) Finally, in Caballero v. the Executor, ${ }^{254}$ a resident of Spain was allowed to recover as a forced heir against a will of personal property in Louisiana. Testator, a naturalized American citizen, executed his will while domiciled in Louisiana. He subsequently abandoned his domicile in that state and went to Cuba; he celebrated there his marriage with a colored concubine, mother of several illegitimate children, whom he was forbidden to marry in Louisiana. When beneficiaries under the will initiated proceedings to carry the disposition into effect, a child thus legitimized by marriage in Cuba claimed a forced share in the estate. The court determined the validity of legitimation according to the law of the place where the marriage was celebrated and the parties domiciled ${ }^{255}$ and the effect of legitimation on the will according to Louisiana law. As a result, the disposition was reduced to the disposable portion.

In contrast to the civil law forum just discussed, in common law jurisdictions - with which the remainder of the instant discussion will be concerned-the domestic policy favoring testamentary freedom is superior to the protection of descendents, resident or not. ${ }^{256}$ On the conflicts level, the protection of "vested rights" of the descendents of a non-resident testator, their lawful expectations, and the recognition of a dominant interest in the country of their residence are considerations in support of the domiciliary rule. Application of a restrictive domiciliary law in the succession to local personal property would, however, run counter to the forum policy of free-

25128 La. Ann. 367 (1876).

252 Succession of Taylor, $25 \mathrm{La}$. Ann. 446, 447 (1873).

253 The dissenting opinion indicated that Louisiana miscegenation statutes were disregarded by the majority. $28 \mathrm{La}$. at 374.

25424 La. Ann. 573 (1872).

255 Id. at 575.

${ }^{256} \mathrm{Cf}$. text at note 236 supra. 
dom of disposition. This policy, apparently covering all property within the jurisdiction and not only that belonging to residents, seems to require that situs and forum law be applied whenever forced heirs relying on the law of a domiciliary civil law country challenge a testator's freedom of disposition over local assets. ${ }^{257}$ Accordingly, the American common law courts have resolved the issue of forced heirship of descendants by generally disregarding restrictions on the testamentary freedom imposed by a domiciliary civil law country. Quite uniformly, forced heirship claims have been denied and the testamentary disposition given effect under the situs law in accordance with the testator's intention. And this is the true common law choice-oflaw rule, the rule actually applied in all cases; situs law-the law validating the disposition-governs.

For historical reasons-and probably due in part to the rigid formulation of the Restatement-this result is not quickly reached. Lip service to the alleged rule is quite frequent and it is only by means of several devices that the courts manage to apply their own law and succeed in upholding the disposition. Those devices are classified in the following discussion as follows: (1) domicile localized at the situs of the personal property, (2) presumption of identity of the foreign law with that of the situs, (3) invocation of the testator's intention that situs law be applied, (4) acceptance of renvoi from the domiciliary law, and (5) preference for the donor's rather than the donee's domiciliary law in the distribution of property subject to a power of appointment. 258

(1) "In courts, rule and decision may dictate the interpretation of facts." ${ }^{259}$ Thus, a desired result may obtain by the device of finding a technical domicile within the forun state ${ }^{260}$-a finding which automatically

257 Cf. text at note 245 supra.

258 No need for such devices has apparently been felt where the will is valid under the foreign domiciliary law and invalid under the law of the situs and forum, for it is an elementary principle of private international law that the applicability of foreign law is limited by the public policy of the forum. See Nussbaum, Princtples of Private Internationad Law 110 (1943). Nor, in cases involving issues of formal validity or construction, is the resort to similar devices any longer necessary; modern legislation bas hiberalized the rule by the adoption of alternative points of reference with respect to formalities, and in cases of construction the rule that the law intended by the testator governs has been generally accepted. $C f$. text at note 96 supra; text at note 336 infra.

259 See Lleweliyn, The Brambie Bush 61 (1953).

260 See e.g., Dupuy v. Wurtz, note 91 supra; Palmer v. Bradley, 142 Fed. 193 (N.D. In. 1905), where the court "assumed" that testatrix, who died in France, was domiciled for "testamentary purposes" in Illinois; Houghton v. Brantingham, 86 Conn. 630, 86 Atl. 664 (1913) (France-Switzerland); Matter of Spitzmuller, 279 App. Div. 233, 109 N.Y.S.2d 1 (Ist Dep't 1951) (Italy); Roberts' Succession, 2 Rob. 427 (La. 1842) (France); Matter of Gifford, 279 N.Y. 470, 18 N.E.2d 663 (1939) (France) ; United States Trust Co. v. Hart, 150 App. Div. 413, 135 N.Y. Supp. 81 (1st Dep't 1912) (France); Matter of Blumenthal, 101 Misc. 83, 167 N.Y. Supp. 252 (Surr. Ct. 1917) (France); Matter of Cleveland, 28 Misc. 369, 59 N.Y. Supp. 985 (Surr. Ct. 1899) (France); Matter of Lynch, 170 Misc. 966, 11 N.Y.S.2d 303 (Surr. Ct. 1939); 
relieves the court from any reference to foreign law in succession to movables. This is a favorite old teclnique, used by the courts as an escape from the domiciliary rule ${ }^{261}$ in the determination of other issues of testamentary succession to personal property. Taormina v. Taormina Corp. ${ }^{262}$ discussed infra, illustrates the situation where such a technical domicile is found for the determination of forced heirship rights of descendants.

(2) By another device, situs law enters through the back door in a number of instances; the courts, in order to give effect to the testator's intention, are ready to indulge in the presumption that the foreign domiciliary law-the law which, if actually applied, would render the disposition invalid-is identical with the situs law. How the law of California can be presumed to be the same as that of China(!) in a case involving community property, ${ }^{263}$ and the law of New York identical with Swiss law in a case involving forced heirship of descendants ${ }^{264}$ but not identical with Italian law where the exercise of a power of appointment for the benefit of an Austrian mistress is in question, ${ }^{265}$ ceases to be a mystery if we look into the facts of eacli case and the equitable results reached under the law of situs and forum. For example, in In re Marsland's Estate, ${ }^{266}$ the beneficiary of a

Harrison v. Nixon, 34 U.S. (9 Pet.) 483 (1835); Cruger v. Phelps, 21 Misc. 252, 262, 47 N.Y. Supp. 61, 68, 70 (Sup. Ct. 1897). "A change of domicile to a foreign country is so injurious to the welfare of families, and affects so radically the validity and construction of testamentary acts ... that it should be established by the clearest and most convincing and satisfactory evidence.... [T] [The evidence to establish a change of domicile should be something more than casual and unadvised statements made without special reference to the technical meaning of the language used. In cases of succession, it requires plain and certain evidence showing a fixed and definite purpose to establish that a person has become a foreigner to his native land." (Emplasis added.) In New York Life Ins. and Trust Co. v. Viele, 161 N.Y. 11, 55 N.E. 311 (1899), testatrix, an American citizen who resided for thirty years before death in Germany, was found to be domiciled in New York although "the facts and the circunstances upon which the finding is based were not so satisfactory and persuasive." Cf. Matter of Lachenmeyer, 144 Misc. 678, 258 N.Y. Supp. 641 (Surr. Ct. 1928), involving localization for testamentary purposes of the domicile of a German national and naturalized American citizen. The court distinguishing previous cases, held that: "It is well settled that more evidence is required to establish a change of domicile from one nation to another than from one state to another. . . This is not a case of a native American possessed of large means who went abroad in search of health or pleasure, such as was the case in those decisions cited by the referee, but rather the case of a retired merchant of advanced years who returned to his native land to spend the remaining years of his life time. In view of the foregoing, the testator's description of himself as of 'New York' has very little weight as affecting the question of domicile."

261 Cf. Matter of Duke, 181 Misc. 529, 41 N.Y.S.2d 745 (Surr. Ct. 1943). Surrogate Delehanty, referring to this practice said that in Dupuy v. Wurtz, 53 N.Y. 565 (1873), the will "was saved only by a holding that her (deceased's) domicile was in this state. In Ames v. Duryea, 6 Lans. 155 (1871), aff'd, 61 N.Y. 609 (1874), another will was saved by a like holding that the domicile was in this state."

262109 A.2d 400 (Del. Ch. 1954), discussed in text at note 290 infra.

263 See Louknitsky v. Louknitsky, 123 Cal. App.2d 406, 266 P.2d 910 (1954).

264 See Matter of Marsland, 142 Misc. 230, 254 N.Y. Supp. 213 (Surr. Ct. 1931).

265 See Matter of Spitzmuller, 279 App. Div. 233, 109 N.Y.S.2d 1 (1st Dep't 1951).

268142 Misc. 230, 254 N.Y. Supp. 213 (Surr. Ct. 1931). 
testamentary trust of personalty with a power of appointment over the principal died domiciled in Switzerland having appointed in her will her husband as sole legatee. This will was given effect in New York, the situs of the trust estate, over the protest of deceased's disinherited children who claimed a forced share under the Swiss (domiciliary) law. The Surrogate presumed "in absence of proof" Swiss law to be the same as New York law and entered a decree awarding to the survivor the entire estate according to the wishes of the testatrix. ${ }^{267}$

(3) The courts of New York, confronted with forced heirship claims more frequently than any other courts in the Union, sometimes resolve the issue by still another device-direct reference to the testator's intention that situs law be applied. ${ }^{268}$ This trend is illustrated in In re Cook's Estate. ${ }^{269}$ An American citizen domiciled in Cuba left his residuary estate to his wife in disregard of his child's right under Cuban law to a forced share in two-thirds of the estate. ${ }^{270}$ The will, executed in Cuba, was originally probated in New York, the situs of decedent's large personal estate. The Surrogate upheld the disposition under New York law, relying on the testator's express intention that "the will be construed under the laws of New York." The court indicated that under both the common law and the statutory law of New York a foreign testator could escape onerous restrictions imposed by his domiciliary law by a declaration of intention that "the will be construed" under the situs law. ${ }^{271}$ The court erroneously treated the issue of essential validity as one of construction. ${ }^{272}$ The decision, nevertheless, is sound; it conforms with the situs policy and the intention of the testator. The reference to this intention and the recognition of the significance of the situs as a connecting factor ${ }^{273}$ enabled the court to apply its own law and

267 For other international cases where foreign law was presumed to he same as the situs and forum law see Matter of Stephani, 164 Misc. 240, 300 N.Y. Supp. 813 (Surr. Ct. 1937); Matter of Klyszewski, 140 Misc. 241, 250 N.Y. Supp. 264 (Surr. Ct. 1931) ; Matter of Meyer, 125 Misc. 361, 211 N.Y. Supp. 525 (Surr. Ct. 1925). Cf. Gallard v. Winans, 111 Md. 434, 74 Atl. 626 (1909); text at note 308 infra.

268 Similar technique was followed in a number of international cases involving issues of succession to movables, other than forced heirship. See In re Stebbins-Vallois' Estate, 99 N.Y.S.2d 402 (Surr. Ct. 1950); Matter of Smith, 182 Misc. 711, 48 N.Y.S.2d 631 (Surr. Ct. 1944) ; Matter of Ryan, 178 Misc. 1007, 36 N.Y.S.2d 1008 (Surr. Ct. 1942) ; Matter of Tabbagh, 167 Misc. 156, 3 N.Y.S.2d 542 (Surr. Ct. 1938).

269204 Misc. 704, 123 N.Y.S.2d 568 (Surr. Ct. 1953), aff'd, 283 App. Div. 1047, 131 N.Y.S.2d 882 (1st Dep't 1954).

270 See CuBA C.C. art. 808 (1888).

271 Section 47 of New York Decedent Estate Law specifically permits the adoption of the law of New York by non-resident testators. The court said that "the concept embodied in the statute was not foreign to the conımon law" and that "Section 47 is merely declaratory of the rule as it theretofore existed" (at 570 ).

272 Cf. text at notes 312,313 infra; note 102 supra.

273 The court declared that New York law is applicable and controlling "when the estate left by the testator is subjected to control by the courts of this state as it was in this case by the selection of a New York fiduciary, by the testamentary transmittal of the property to this jurisdiction and by the direction as to the governing law (at 570)." 
to reach a desirable result without mentioning the renvoi theory of the celebrated Schneider decision which we will discuss shortly, ${ }^{274}$ although the law of Cuba referred the issue of succession to the "national" law of deceased. $^{275}$

In re Feuermann's Will ${ }^{276}$ offers another illustration of direct reference to the testator's intention. Feuermann, the celebrated Austrian cellist, while domiciled in Switzerland executed a holographic will placing his wife in the most advantageous position under the Swiss law. He further directed that in case of subsequent change of domicile the widow be again placed "under the most advantageous position under the laws then applicable to us." The widow sought in New York, the situs of the personal property and deceased's domicile at death, a judicial determination that she was entitled to the entire estate to the exclusion of the only issue of her marriage with deceased, an infant born shortly following the execution of the will. The court awarded to her the entire estate according to the law of New York. ${ }^{277}$ But the application of that law was based on the express intention of the testator rather than on the domiciliary rule.

Similarly, contrary to the law of the testator's domicile, the disposition was upheld in In re Tomacelli-Filomarino's Estate ${ }^{278}$ the court again relied on deceased's intention. Testator in that case died domiciled in Mexico; his will was originally probated in New York, the situs of his personal property. The court found that "the provisions of the will clearly indicate the decedent's intention that it be construed in accordance with the law of the state of New York." As a result, the claim of an illegitimate child born to decedent subsequent to the execution of the will ${ }^{270}$ was denied although

274 In re Schneider's Estate, 96 N.Y.S.2d 652 (Surr. 1950), affd, 100 N.Y.S.2d 371, 80 N.E.2d 667 , reh. denied, 82 N.E.2d 29 , discussed in text at note 284 infra.

275 See Cuba C.C. art. 10 (1888).

27647 N.Y.S.2d 738 (Surr. Ct. 1944). The case is discussed in Nussbatra, AmericanSwiss Private Internationar Law 25 (1951).

277 The child had no forced heirship rights under the applicable law of New York and the contest turned on the question whether the infant was sufficiently "mentioned or provided for" within the meaning of the New York Decedent Estate Law. The fact that, notwithstanding the absence of any provision in the will for its benefit, the infant would have received under Swiss law the entire estate subject only to the "sufruct" of the widow, was held to constitute suffcient mention by implication!

278189 Misc. 410, 73 N.Y.S.2d 297 (Surr. Ct. 1947) (nationality of deceased, place of execution of the will, and identity of the heneficiary not known).

278 The special guardian, apparently conceding that New York law governed succession, contended that the child, having not been "mentioned in the will or provided for," was entitled to take against the will under Section 26 of the New York Decedent Estate Law. The court held that only "legitimized" children, as distinguished from "recognized," can inherit under that section and left the disposition undisturbed. With respect to the rights of illegitimate children, see Succession of Petit, 49 La. Ann. 625, 21 So. 717 (1897) (France) ; Vergnani v. Guidetti, 308 Mass. 450, 32 N.E.2d 272 (1941) (Italy); Danelli v. Danelli, 67 Ky. (4 Bush.) 51 (1868) (Italy); Matter of Vincent, 71 N.Y.S.2d 165 (Surr. 1947) (Haiti); In re Krabbe's Estate, 158 N.Y.S.2d 551 (Surr. 1957) (Denmark). 
that child had been formally recognized in Mexico and had a right to a forced share under Mexican law.

Determination of forced heirship of descendants according to the law expressly or impliedly designated by the testator conforms, better than the "logical" postulates of the Restatement, with the forum policy favoring testamentary freedom. It is doubtful, however, whether the courts would go so far as to recognize testator's autonomy to select a non-domiciliary and non-situs law. ${ }^{280}$ The fact that all cases were ultimately decided according to the situs and forum law casts doubt on the.broad language of the decisions discussed ${ }^{281}$ and seems to indicate that this "autonomy" trend is but one of the devices importing local law whenever the disposition is valid according to domestic standards and invalid under the law of the foreign domicile. ${ }^{282}$

(4) A fourth device, renvoi, the "most controverted and most famous dispute in the law of conflicts,"283 was until recently excluded from the American conflicts law of succession to personal property. But in the much debated case of In re Schneider's Estate, ${ }^{284}$ the New York Surrogate applied New York law to the succession of a dual Swiss-American national on a renvoi theory. Deceased, admittedly domiciled in New York, left a will disposing of both property situated in New York and land in Switzerland. The proceeds of the Swiss real estate had been remitted to New York and controversy arose as to the law governing the distribution of that fund. Forced heirs asserted their rights to a legitime under Swiss law; the beneficiary under the will, on the other hand, insisted that New York law governed and that the disposition should be given effect as made by the testator. The Surrogate, apparently anxious to overrule the "outmoded" Tallmadge decision, ${ }^{285}$ accepted renvoi as a part of the law of New York ${ }^{286}$ and came

$280 \mathrm{Cf}$. the broad language $I n$ re Cook's Estate, note 269 supra at 570.

$281 C f$. cases cited in notes $269,276,278$ supra.

$282 C f$. note 258 supra.

283 Rabed, Conflict of Laws: A Comparative Study 70 (1945).

28496 N.Y.S.2d 652 (Surr. Ct. 1950), afjd 100 N.Y.S.2d 371, 80 N.E.2d 667, reh. denied, 82 N.E.2d 29.

285 Matter of Tallmadge, 109 Misc. 696, 181 N.Y. Supp. 336 (Surr. Ct. 1919).

286 This against RESTATEMENT, Confzict of LAWS $\$ 8$ (1934), limiting the acceptance of renvoi to foreign divorce decrees and questions of title to land. Most American writers also agree that renvoi should be limited to a few select situations. See BEALE, Conftict of Laws 56, 57 (1935) (foreign divorce decrees and title to land); Cormack, Renvoi, Characterization, Localization, and Preliminary Question in the Confict of Laws, 14 So. CALTF. L. REv. 221, 262 (1941); Lorenzen, The Renvoi Doctrine and the Conffict of Laws; Meaning of the Law of a Country, 27 YaLE L. J. 509, 529 (1918); Falconbridge, Renvoi, Characterization, and Acquired Rights, 17 CAN. BAR Rev. 369 (1938). But see Griswold, Renvoi Revisiled, 51 HARv. L. REv. 1165 (1938); Cowen, Renvoi Does Not Involve a Logical Fallacy, 87 U. PA. L. Rev. 34, 49 (1938) ; RABEI, CoNFLICT OF LAWS 72 (1945) (stressing the significance of the policy considerations that should prevail at the forum and suggesting that "the entire problem is not to be taken in the lump and decided on a priori reasoning"). 
out with a result which could be reached in other less complicated ways. ${ }^{287}$ The court, for the purpose of retaining jurisdiction, characterized the proceeds at the outset as movables; then, for the purpose of distribution, recharacterized the same as immovable stating that the substituted fund represented the foreign land itself. ${ }^{288}$ Thus, according to well-settled conflicts rules the validity of the devise should be tested by Swiss situs law. But, as that law subjected the entire estate-personal and real-to the law of the last domicile ${ }^{289}$ and rejected renvoi, the court held that New York law, the law of the testator's domicile at death and situs of the substituted fund, governed. As a result, the testamentary scheme was upheld and the claim of the Swiss forced heirs was demed.

The Delaware Chancery Court in its decision in Taormina v. Taormina Corp., ${ }^{200}$ applied the Schneider renvoi theory to a situation of "transmission" rather than "remission." 291 Testator, a naturalized citizen, in a will executed in Mississippi and originally probated in Italy, named his wife and son universal legatees and disinherited a daughter by a former marriage from any interest in the estate. Deceased's daughter contested the validity of the disposition in Delaware, seat of ancillary administration and situs of personal property, claiming a forced share. She alleged that testator died domiciled in his native Italy, where he had spent his last ten years, or in Louisiana and that under the choice-of-law rules of the forum the law of Italy or that of Louisiana should govern succession-each law granting to her the right to a forced share. The court, contrary to much of the evi-

287 E.g. by simply applying the law of the domicile at death (New York), following a characterization of the fund as "movable." See Notes, 40 Cox. L. Rev. 862 (1950); 64 Harv. L. REv. 166 (1950); 35 MinN. L. REv. 87 (1950).

288 If, according to the law of New York determination of title to a fund representing foreign realty is equivalent to determination of title to the realty itself, the Surrogate's jurisdiction is not free from doubt. See citations at 96 N.Y.S.2d 657.

289 This is doubtful. See Nussbaum, Amrerican-Swiss Prtvate Internatronal Law 22 (1951), arguing that the decision in the Schneider case disregarded Swiss authorities interpreting the Conflicts Law of Switzerland, and violated, if not the letter, the spirit of the SwissAmerican Treaty of 1850. See also, JournaL du Droit INTERnationaI 657 (1950).

280109 A.2d 400 (Del. Ch. 1954).

201 "Remission" (Rueckverweisung), indicates that the foreign law referred to by the conflicts rule of the forum "rennits" the question to the forum. The term "transmission" (Weiterverweisung), is preferred when the foreign law instead of remitting the question to the law of the forum, "transmits" it to the law of a third legal system. See NussBaUdr, PrINCapLes of PrTvate International Law 99 (1943). While it is disputed whether the renvoi doctrine, in the sense of the reference back to the forum is part of the common law, the Delaware court accepted the "transmission," the reference to the law of a third state, which even jurisdictions adopting renvoi ordinarily decline to consider. See NUSSBAUM, DEUTSCErs Irternationales Prtyatrecht 56 (1932); Rabes, Conflict of LaWs 73 (1945); Wolf, INternattonates Privatrecht 49 (1933); and in general, Schreiber, The Doctrine of the Renvoi in the Anglo-American Law, 31 HARv. L. REV. 523 (1918). 
dence, ${ }^{282}$ found that deceased had died domiciled in Mississippi and held that according to the law of that State the disposition should be upheld. But, evidently, the court was not satisfied with the finding of a technical domicile in a state in which the testator had spent hardly two years of his lifetime and, on a renvoi theory, based its decision on the alternative ground that, though deceased died domiciled in Italy, Mississippi law governedthe law of the last American domicile. If deceased died domiciled in Italy, the court said, still Mississippi law governs because the Italian law refers the issue of succession to the "national" law of deceased. ${ }^{203}$ Thus, assuming that its own conflict rules referred the issue of forced heirship to the "entire" domiciliary law of the testator including the choice-of-law rules of that law, and supposedly "sitting and judging as in the testator's domicile," 294 the court identified the law of Mississippi as the "national" 205 law

282 The deceased had emigrated to New Orleans, Louisiana, in 1920, and resided there for twelve consecutive years. He went to Italy in 1932, married there, and came back with his wife to live in Dona, Texas. Next year, however, he moved back to New Orleans for reasons of health. Deceased moved to Gulfport, Mississippi, in 1934, and hived there until 1936 when he sailed with his family for Italy. During the World War II, he was drafted in the Italian Army, and at his death in 1946, a certificate issued by the local authorities listed him as domiciled in Partano, Italy.

293 See DISP. Prex, art. 23 of the Itazian CrvI Code of 1942, which refers succession to the law of the state whose citizen the deceased was at the time of death. See also PaIIIERE, Diritto Internaztonate Privato 207-216 (1950); Morelli, Elementi di Diritto Internazionale Privato Italiano 126-134 (1952). Renvoi is rejected in Italy. Civ. Code Disp. Prei. art. 30. The statement of the Delaware court, therefore, that "when a non-Itahian national dies in Italy, whether or not he is there domiciled, the Italian court will apply the principle of renvoi, and refer the distribution of his estate to the law of the decedent's nationahty," 109 A.2d 400, at 405 , is inaccurate. (Emphasis added.)

284 The court apparently adopted the "foreign court theory," a refinement of the renvoi doctrine developed by the English courts, whereby the forum disposes of the controversy as would the foreign court applying both the latter's conflict and renvoi rules. Sce Collier v. Rivaz, 2 Curt.Ecc. 855 (Ecc. Ct. 1838); In re Annesley, [1926] Ch. 692; In re Ross, [1930] 1 Ch. 377; In re Askew, [1930] 2 Ch. 259; In re Duke of Wellington [1947] Ch. 506, affd, [1948] Ch. 118 ; Kotia v. Nahas, [1941] A.C. 403. For a criticism see CheshrRe, Private International Law 70 (1952). Dean Griswold recommends this Enghish doctrine "unless clearly unworkable," feeling that the "frightful" endless chain "is only a remote possibility of renvoi, magniffed by theorists into its central theme." Griswold, Renvoi Revisited, 51 Harv. L. REv. 1165, 1192 n. 6 (1938). RaBel, Confuict of Laws 76 (1945), believes that this English doctrine is a "praiseworthy contribution to international harmony." Cf. Nussbaum, Principles of Private InterNATIONAT LAw 97 (1943). This theory, however, yields satisfactory results only when it is adopted in one country and rejected in the other. See Chesmire, Private Internationat Law 76 (1952). If adopted in all jurisdictions concerned, the result of the theory would be an endless merry-go-round. See Nussbaum, Principles of PrJvate InTERnational Laiv 98 (1943).

295 The assumption that in a similar case the Italian courts would apply the law of Mississippi does not seem warranted in view of recent developments in Italy. When a national of a country with a composite legal system died domiciled abroad, the Italian courts applied in the past the law of the domicile of origin as his national law. See RaBEL, ConfLICr of Laws 131 (1945). Thus, the English decisions cited supra in note 294 seem supported by Italian law. But where was the domicile of origin of the testator in the Delaware case? Was it in Louisiana, Mississippi, or rather in Italy ? Modern Italian writers suggest that when there is no substantive 
of the testator on the belief that it was applying establislied Italian doctrine. ${ }^{298}$

Application of situs and forum law would liave rendered unnecessary the resort to the renvoi doctrine, ${ }^{297}$ the highly teclnical reasoning of the Delaware court, the questionable interpretation of foreign doctrine, and the far-fetched search for a legal system that would save the will. If the forum policy is clearly against restrictions on the testainentary freedom for the benefit of the testator's descendants, the solution is to be found in the

"national" law, as in the case of an American domiciled abroad, the Italian courts should apply their lex fori. See de Nova, 15 ANN. DiRItTo Comp. 338 (1941); dE Nova, It Richiamo dI Ordna (1940) ; and Grassetr, L'ART. 9 Disp. Prec. CoD. Crv.; La Forma di Testamenti ed un pretesa caso di Applicazione della Teorica del Rinvio, 5 RrvisTa DI DIR. PR. 3 (1935), cited Falconbridge, Renvoi and the Law of the Domicile, 19 CAN. BAR REv. 311, 323 n.34 (1941) (principal works not available).

298 What is the "national" law of an American citizen? The Umited States has no substantive law of succession and a reference to the "national" law of an American citizen domiciled ahroad does not in itself afford any guide for the selection of the law of any particular state of the United States. It is only when an American citizen is domiciled within a state of the Union that the concept of state citizenship inay be utilized and the reference to the national law interpreted as requiring apphication of that body of law which would be applied by a court sitting at the domicile. See RABEI, Confurct of Laws 134 (1945). However, an American domiciled abroad is not any longer a citizen of a particular state; such an individual is still an American citizen but not a citizen of the particular state. See Prentiss v. Brennan, 19 Fed. Cas. 1278 No. 11385 (N.D.N.Y. 1851) ; Hammerstein v. Lyne, 200 Fed. 165 (W.D.Mo. 1912). See also Rheinstein, Lo Statuto Personale dei Sudditi degli Stati Uniti d'America, Gror. Comp. DI DrR. INT. PRrv. 141, 144 (1937). Thus, there is no "national" law of succession for an American domiciled abroad. See Rabel, The Form of Wills, 6 VAND. L. Rev. 538, 541 (1953) ; Rennstenv, Das Kolitsiosrecht mi Systear des VerfessungsRechts der VereINigten StaAten voN AMIERICA, IN FESTSCHRIFT FUER ERNST RABEI 539 (1953).

Where reference is made to a composite legal system having no interregional conflict rules, and the individual is domiciled outside the national country, the prevailing continental view is that the law of that district of the foreign country where the individual had his last domicile should be apphed, or if he never had any domicile in his national country, the law in force at the capital of that country. See RABEL, CONFLICT OF LAwS 130 (1945) ; NIEMEYER, DAS INTERnationale Privatrecht des B. G. B. 68 (1901) ; Meichior, Dif Grundtagen des DeutcheN Internationaten Privatrechts 452 (1932); Ziteriarann, Internationates Privatrecht 395 (1897); RaApe, Deutches Internationales Privatrecht 36 (1938); and $c f$. Keger, Die ANwendung des Rechts Auslaendisher Staaten Mit RabuMilicher Rechtsspattung, Kart ARNOLD FESTSCHRIFT 61 (1955). Quite a few European courts, in the case of Aunerican citizens domiciled outside the United States, have applied the law of the American state where these individuals had their last domicile on the erroneous assuniption that state citizenship still continued in existence. See Rheinstein, Lo Statuto Personale dei Sudditi degli Stati Uniti d'America, Crur. COMrP dI DIR. INT. PrIv. 141, 144 (1937).

297 The main purpose of the renvoi doctrine is the achievement of uniformity and of results that would be recognized at the situs of the personal property. See Coor, THE LOGICAI AND Legat Bases of the Confutct of Laws 244 (1949). Thus, the resort to the doctrine of renvoi in cases where the Anierican forum adjudicates inheritance rights over local personal property seems unjustifiable. Were the domicile in the United States and the situs in a civil law jurisdiction, resort to renvoi might be a solution to the forced heirship problem; but no such cases have been found. 
situs law rather than in the renvoi doctrine as an escape from the domiciliary rule.

(5) The remaining device utilized by courts to circumvent the domiciliary rule is selection of the donor's domicile law when a power of appointment is exercised. When, in 1838, the Privy Council faced the question whether the will of an English testator, valid according to the law of the place of execution (France) but invalid under the law of domicile at death (Italy), should be carried into effect in England, Lord Brougham in order to save the will seized at a straw. ${ }^{298}$ Leaving intact Stanley v. Barnes, ${ }^{290}$ and other older precedents establishing the principle that testamentary succession to personal property was governed by the law of the testator's domicile at death, Lord Brougham stressed the fact that the will attempted to exercise a power of appointment conferred by an English donor over property situated in England and declared that the donee's succession was governed by the domestic law of England. "The real question," he suggested, "is not whether this is a testamentary instrument according to the law of the domicile, for we adinit, as far as the execution of it goes, that it does not conforin to the Napolitan law, but whether it is not a part of Mr. Boone's will [the donor of the property] carrying into effect the provisions he made respecting the ultimate disposal of his estate." Accordingly, the will was admitted to probate and carried into effect.

The cases following Lord Brougham's reasoning soon grew too numerous to be regarded as an exception of the domiciliary rule; they were rationalized instead as establishing a new conflicts rule-that the donor's domiciliary law governs the exercise of powers of appointment. ${ }^{300}$ The new rule was successfully transplanted first to Pennsylvania ${ }^{301}$ and Massachusetts, ${ }^{302}$ then to other jurisdictions, and finally found its way into the Restatement of the American Law Institute. ${ }^{303}$

298 Tatnall v. Hankey, 2 Moo. P.C. 342 (1838).

299 See text at note 47 supra.

300 In re Sophia Alexander, 8 W.D. 451 (1860); Goods of Hallyburton, L.J. 1 P.\&D. 122 (1866); In re Goods of Huber, L.R.P.\&D. 209 (1900) ; Murphy v. Deichler (1909), A.C.446; Pouey v. Hordern, L.R. 1 Ch. D. 492 (1900) (all cases involving validation under the donor's domiciliary law of wills invalid under the donee's domiciliary law). Some courts distinguish between "restricted" or "special" and "unrestricted" or "general" powers. See Goodricr, CoNFLICT of Laws 530 (1949 ed.). Cf. In re New York Life Ins. and Trust Co., 139 N.Y. Supp. 695, 704 (Surr. Ct. 1913). "There is a great distinction, not, I think, noticed in the American cases cited to me by the counsel, nor in the briefs of the learned counsel, between "powers" which are the property of the donee of the power and "powers" which are the property of the donor of the power. The principle of domicile may apply to one and not to the other." In re Waite's Settlement, 2 W.L.R. 1024 (1957); Note, Power of Appointment in the Conflict of Laws, 73 L. Q. REV. 459 (1957).

301 Bingham's Appeal, $64 \mathrm{~Pa} .345$ (1870).

302 Sewall v. Wilmer, 132 Mass. 131 (1882).

303 Restatement, Confict of Laws $\S 287$ (1934). See also 2 Beale, Conflict of Laws 1011 (1935); Goodrtci, Conflict of Laws 530 (1949 ed.); Stumberg, Conftict of Laws 428 (1951); WHaRTon, CoNFutet of Laws 441 (1872). 
However, whether involving interstate or international conflicts, the cases can be reconciled only on the ground that the exercise of powers of appointment and the disposition of property subject to such powers is governed by the law which would best realize the testator's intention. ${ }^{304}$ The legalistic language of the courts and the thin disguise of the forum interest in the succession under the clothing of the donor's domicile gave rise in the past to difficult questions, particularly with respect to estate taxation. ${ }^{305}$ The real issues were hampered by the conceptualistic theory that the donee of the power was simply the agent of the donor, a view outmoded and inconsistent with economic and social facts. ${ }^{306}$

In the field of forced heirship, the power of appointment rule has been invoked to validate, under the forum and situs law, dispositions invalid under the domiciliary law of the testator. In Gallard $v$. Winans, ${ }^{307}$ testatrix, a former American citizen married to a French nobleman, died in Russia. In a will executed in Paris and probated in Baltimore - the situs of a large personal estate over which she had a power of appointment - testatrix named her husband sole beneficiary and made no provision for her two minor children who were entitled under the law of France to a forced share. The court held that the law of the donor's domicile governed and upheld the disposition under the law of Maryland. "The rule is, in our judgment, applicable with special force to a case like the present one," the court declared, "where the domicile of the donor and the location of the property subject to the power are the same. Even if we were to hold that, because the property consists of personalty, its disposition should be governed by the law of France, of which testatrix had become a citizen, the French law, in the absence of proof to the contrary, will be presumed to be the same as ours." $"$ "308

In re O'Connor's Estate, ${ }^{309}$ also involving forced heirship and the exer-

${ }^{304} \mathrm{Cf}$. notes 164,330 . That the resort of the donor's domicile is merely a device is best evidenced in cases where donor and donee is the same person! See, e.g., In re de Von der Hallen's Trust, 169 N.Y.S.2d 698 (Special Term 1957); In the matter of Spitzmuller, 279 App. Div. 233, 109 N.Y.S.2d 1 (1st Dep't 1951). The same is true where the donee is given a general power. In such cases to imsist on the distinction "would be to grasp at a shadow while the substance escapes," St. Leonard's Powers 396 (8th ed.).

305 See Matter of Canda, 197 App. Div. 597, 189 N.Y. Supp. 917 (Sup. Ct. 1921) ; Eisenstein, Powers of Appointment and Estate Taxes, 52 YaIE L.J. 494 (1943); Griswold, Powers of Appointment and the Federal Estate Tax, 52 HaRv. L. REv. 929 (1939); Scoles, Apportionment of Federal Estate Taxes and Confict of Laws, 55 Colus. L. REv. 261, 283 (1955).

${ }^{306}$ See Scoles, Apportionment of Federal Estate Taxes and Conflict of Laws, 55 CoLun.

L. REv. 261, 283 (1955). Cf. Mulford, The Confict of Interests in Powers of Appointment, 8 U. PA. L. REv. 403 (1939).

307111 Md. 434, 74 Atl. 626 (1909).

308111 Md. at 470,74 Atl. at 631 . Cf. notes 266, 267 supra.

30982 N.Y.S.2d 310 (Surr. Ct. 1948). Cf. In re Barnhart's Will, 137 Misc. 518, 244 N.Y. Supp. 130 (Surr. Ct. 1930), note 371 infra. 
cise of a power of appointment, offers an interesting contrast. The life beneficiary of a trust of personal property in New York with a power of appointment over the principal, an Italian citizen domiciled in Italy, left the "freely disposable" share of her estate to a friend. She was survived by two sons who, under the law of Italy, were entitled to a forced share in two-thirds of the estate. In a proceeding initiated in New York for the construction of the will, the court relied on situs law as such to hold that New York law governed. ${ }^{310}$ But the court found that it was the intention of the testatrix to dispose only one-third of the estate-that part that she could freely dispose under Italian law-and gave effect to this intention. As a result, the friend of the testatrix received one-third of the estate and her two children took the other two-thirds-not by virtue of Italian law but rather by virtue of a gift to them in default of exercise of the power. ${ }^{311}$

\section{Interpretation and Construction}

If a will is formally and essentially valid, the court at the situs of the personal property should enter a decree of distribution carrying the testator's intention into effect. This may involve a process of interpretation of the will-that is, determination of the actual intention of the testator ${ }^{312}$ and whenever this is not possible, a process of construction-determination of the meaning that the law attributes to the language used as presumably intended..$^{313}$

In many cases the distinction between interpretation and construction is

310 The court relied on the situs law as such rather than on the donor's domiciliary law, and held that "since the original successor and substituted trustees were New York residents and the trust property has always been situated and administered in New York, New York law governs the trust and the validity of the exercise of the power of appointment" (82 N.Y.S.2d at 312).

311 The original trust deed provided that the bife beneficiary would have the power to dispose of the principal "by will duly executed according to the laws of the place where she may be domiciled," and in default of such will, "the principal would go to her children." Cf., In re Waite's Settlement, 2 W.L.R. 1024 (1957) where an English court under similar facts awarded the entire estate to the designated beneficiary under English law.

${ }^{312}$ See Matter of Kadjar, 200 Misc. 268, 102 N.Y.S.2d 113 (Surr. Ct. 1950). See also 2 Beate, Confutct of Laws 972 (1935); Goodrich, Confutct of Laws 515 (1949 ed.); NUSSbaum, American-Swiss Private Internationat Law 26 n.88 (1951); Breslauer, Private Internattonal Law of Succession 132 (1937); Cheshitre, Private International Law 536 (1952). The Restatement distinguishes between interpretation, construction and effect of wills of lands (RESTaTEMENT, ConfLict of LAWS § 251), but with respect to wills of movables distinguishes only between interpretation and effect. RESTATEMENT, CoNFLICT of Laws $\$ \S 306,308$ (1934).

$\mathbf{3 1 3}$ Beale rejects the term "construction" as ambiguous; he suggests instead the use of the word "effect". See 2 Beate, Conflict of Laws 972 (1935). Cf. Restatement, Confuict of Laws $\$ \$ 251,306$ (1934); Cheshire, Private International Law 536 ff. (1952); Breslauter, Private International Law of Succession 119 (1937); WolfF, Private International Law 599 (1945); BatIFFOI, DroIt InTERNatTonal PrIvÉ 672 (1949). 
clear; in others it seems to disappear. ${ }^{314}$ This distinction, however, is necessary for an understanding of the issues confronting the courts and can be easily understood by an analysis of the nature of those processes. Interpretation involves the establishment of a fact $\mathrm{im}$ accordance with rules in the nature of evidence and is hardly a choice-of-law problem. ${ }^{315}$ Construction, on the other hand, involves an issue of law to be determined in accordance with "directory" rules-legal rules attributing a certain meaning to the language used in absence of manifest intention-and may present a choice-oflaw problen.. ${ }^{316}$

\section{Interpretation}

Few wills are entirely free from abiguity with respect to the testator's intention; interpretation is almost always needed. Very frequently this intention is obscured by incomplete definitions, by the use of foreign language or technical terms of a foreign legal system, ${ }^{317}$ or even by the existence of foreign contacts-for example, a foreign place of execution or a foreign domicile at the time of execution or death.

The courts clarify such ambignities and try to ascertain the testator's intention by employing all available means at their disposal and, in doing so, take into account all the surrounding cirmustances. Thus, in a succession involving foreign contacts consideration of foreign law becomes natural; but foreign law here is simply one of the circumstances and does not control the outcome as it does in a case where that law is applicable in accordance with choice-of-law rules. ${ }^{318}$

314 Cf. Matter of Kadjar, 200 Misc. 268, 102 N.Y.S.2d 113 (Surr. Ct. 1950) ("In applying the rules for construction of a will, confusion sometimes results from the failure to distinguish between a inere interpretation and a pronouncement as to the legal effect of a provision"); notes 322-23 infra; Note, 38 In.. L. REv. 337 (1944).

310 Cf. Cheshire, Private International Law 536 (1952).

316 Cf. Breslauer, Prtvate International Law of Succession 132, 133 (1937); Cheshire, Prtvate Internationad Law 536 (1952).

317 Cf. Restatearent, Confuict of Laws $\$ 308$, comment $c$ (1934): "If a will is written in a language not that of the decedent's domicile, techmical terms contained in the will will be interpreted in accordance with the usage of the language in which they are written." See In re Tomljenovich, 154 N.Y.S.2d 327 (Surr.1956).

318 See, e.g., In re Garfunkel's Estate, 71 N.Y.S.2d 693 (Surr. Ct. 1947). Testator, while domiciled in Belgium, executed a will and named his grandson sole beneficiary. In a proceeding for the construction of a clause in the will related to an attempted appointment of testamentary guardians in New York, situs of the personal property and admittedly domicile at death, the court looked "to Belgium law and the custom and usages of that country only to learn what was in the testator's mind when he used certain terms in the will." The legal effect of the testamentary provisions was determined according to the law of New York. Under that law the attempted appointment of testamentary guardians operated to constitute "the persons named as donees of a power in trust of the property passing to the infant under the will." See also Matter of Fricke, 122 Misc. 427, 202 N.Y. Supp. 906 (Surr. Ct. 1924). There, the testator, a New York citizen, by a will executed in the German language in Germany, left his business and its "current account" ("Kontokorrent") with a local New York bank to his manager in New 
Whenever the testator's intention can be established with some degree of certainty by a process of interpretation, construction may become unnecessary and the choice-of-law issue avoided. For example, In re Kapell's Will, ${ }^{319}$ testatrix died domiciled in Germany. In a will executed in the English language in Switzerland she named her son universal legatee with the direction that upon his death without "heirs" the estate should devolve to certain designated relatives. The son died without issue and his next-of-kin claimed the estate, consisting of personal property in New York, as his "heirs." The court did not even attempt a construction since it was apparent in view of the factual situation that testatrix did not provide for the contingency of her son dying without "heirs" but rather without "issue." In accordance with this intention of the testatrix, the designated remaindermen were awarded the estate without reference to the law governing construction. "In construing the language of the will," the court said, "it makes no difference whether the law of Germany or of New York governs construction. It is the intention of testatrix which controls."

Similarly, in New York Life Insurance and Trust Co. v. Viele, ${ }^{320}$ an American testatrix who for a period of thirty years preceding death resided in Germany, left a legacy to her daughter for life with remainder to her daughter's "lawful issue." The life beneficiary was survived by only an adopted child. This child, having "under the laws of the country of adoption," Saxony, all the rights of a child born in lawful wedlock, claimed the remainder as the designated "lawful issue." The court stated that "the question is not what was the precise status" of the adopted child "but what

York. Under German law the technical term "Kontokorrent" had a much broader meaning than the term "current account," and included all kinds of special deposits. The court refused to give effect to the disposition according to the German law. "Extrinsic evidence was taken," instead, "of the surrounding facts and circumstances, to aid in determining the intention of the testator." And, on the basis of very careful consideration, the court was able to conclude that the testator actually intended to leave to his manager only the current account of his business. In re Tomijenovich, 154 N.Y.S.2d 327 (Surr. 1956), involved construction of a domestic will written in foreign langnage. The court said: "Where a will is written in a foreign language, the court may look to usages and customs of the person writing such language to determme the testator's intent, but the validity and legal effect of these testamentary provisions are to be determined by the law of New York."; see In re Hischmann's Estate, 124 N.Y.S.2d 801 (Surr. 1953); cf. Matter of Kadjar, 200 Misc. 268, 102 N.Y.S.2d 113 (Surr. Ct. 1950); Note, 94 A.L.R. 230 (1934).

319120 N.Y.S.2d 52 (Sup. Ct. 1953). See also Matter of Mayer, 84 Misc. 9, 145 N.Y.Supp. 665 (Surr. Ct. 1914). Testator, a French domiciliary, left personal property in France and New York. In the last of two valid wills, executed in France, testator included certain apparently contradictory provisions with respect to the nomination of executors. Both wills were admitted to probate in New York as interdependent. In a proceeding in that state for the determination of the persons entitled to letters testamentary, the court after considering all the pertinent facts came to the conclusion that the testator's "actual" intention was not to revoke the nomination of American executors made in the earlier will. Consequently, no reference to the law governing construction was made. Cf. In re Bishop's Estate, 129 N.Y.S.2d 387 (Surr. Ct. 1954), aff'd, 3 N.Y.2d 294, 165 N.Y.S.2d 86 (1957) (England).

820161 N.Y. 11, 55 N.E. 311 (1899). 
the testatrix meant when she devised the remainder to the 'lawful issue" " of her daughter-an issue of construction. And, having already found that testatrix was domiciled in New York, the court held that under New York law the words "lawful issue" did not include adopted children. But the court did not actually rely on such a rule of construction of deceased's technical domicile. ${ }^{321}$ Instead, by a process of interpretation and by a very careful consideration of the entire factual situation it came to the conclusion that the actual intention of the testatrix and the "more reasonable construction to place upon the words 'lawful issue" "was to transmit the whole estate to her own descendants, her other grandchildren.

A similar technique was followed in several cases involving bequests of foreign currency. But in a number of such cases, though the courts avoided the choice-of-law issue by directly finding the "intention" of the testator, determination was actually inade in accordance with the forum rules of construction, attributing to the langnage used a certain definite meaning.

In cases involving bequests of foreign currency made in domestic wills, concealing "construction" under the appearance of "interpretation" 322 is

321 Testatrix had resided in Germany for thirty years preceeding death. See note 260 supra. For other cases involving inheritance rights of illegitimate and adopted children see note 279 supra.

322 In In re Lendle's Estate, 250 N.Y. 502, 166 N.E. 182 (1929), a German national domiciled in New York, left certain legacies payable in "marks." The value of the mark since the execution of the will and the death of the testator had been depreciated and revalued. The Surrogate ordered payment of the legacies at the rate of exchange prevailing at the time of execution of the will; the Appellate Division at the time of death, thus practically annihilating the bequests; and the Court of Appeals adopted the rate of exchange at the time of paynent. The conclusion of each court was based on "the intention of the testator," eacb attributing to the language used a different meaning. This, I believe shows the real nature of the process involved; the courts, dealing with a domestic will, construed it in accordance with what they thought to be prevailing rules of construction at the forum. Cf. In re Worth's Estate, 132 N.Y.S.2d 98 (Surr. 1954) ; Comment, 1954 WASE. U.L.Q. 464; Matter of Heck's Estate, 203 Misc. 788, 116 N.Y.S.2d 255 (Surr. 1952) (bequests of gold marks; held, gold mark a fixed value at the time of execution of the will).

Chemical National Bank v. Butt, 123 Misc. 575, 206 N.Y. Supp. 36 (Sup. Ct. 1924), also involved bequests of foreign currency made in a domestic will (francs). In a proceeding for the construction of the will the court found as a fact that the testator intended to leave to his beneficiary "gold francs." Though there may be some doubt with respect to the process followed by the court, it seems that the result reached was based on both interpretation and construction. The court found on the basis of a factual analysis that the testator meant "real francs in coin"; but cutting off any reference to foreign law, the court was quick to state that "This will is the will of a resident of this state, and the estate is administered bere. The annuity bas been created and is payable here," thus justifying the application of New York law.

Similarly, in Volpe v. Benavides, 214 S.W. 593 (Texas Ct. Civ. App. 1919), a Texas domiciliary left certain legacies payable in "Mexican pesos." The trial court found as a fact that the testator intended to bequeath "silver or gold" pesos, to be paid one-half in Mexican silver coin and one-half in gold coin. The court of appeals adopted the interpretation that the testator intended to bequeath "Mexican pesos, silver or gold," but modified the trial court's order with respect to the way of payment. That matter, according to the appellate court, was not an issue of interpretation of the will but of "construction" to be placed on the language. According to the Texas rules of construction, testator had given to the executors an option to pay either silver or gold coins at the prevailing rate of exchange. No reference to foreign law was unade 
not injurious since the will would, in any event, be construed in accordance with domestic standards. But in cases like that of In re Manus, ${ }^{323}$ involving a bequest of Dutch guilders made in the will of a domiciliary of Netherlands, this approach which excludes possible application of foreign law may result in a disposition not intended by the testator. The New York court in that case, "presumed" the intention of the deceased to be that "legacies in guilders would be paid at the rate prevailing on the date when payment was made," thus circumventing the choice-of-law issue. This case, however, cannot be properly regarded as one requiring only interpretation; the court was unable to establish the actual intention of the testatrix and had to "presume" it. What the court did in effect was to attribute to the language used a certain meaming in accordance with the rules of construction prevailing at the situs.

\section{Construction}

It often happens that, although the meaning of the language used by the testator is precisely fixed, ambiguity arises as to his intention due to inadequate planning, unforseen contingencies, or changed circumstances, and the courts are called to resolve issues such as the effect of the predecease of the legatee, ${ }^{324}$ whether a legacy lapses, ${ }^{325}$ what passes under the residuary clause, ${ }^{326}$ whether a beneficiary is put to his election, ${ }^{327}$ the effect of the partial invalidity of the will, ${ }^{328}$ who is the testator's or the legatee's "lawful heir," ${ }^{20}$ or whether a power of appointment has been exercised. ${ }^{330}$ In a case involving exclusively domestic contacts all these is-

since, except for the bequest of foreign currency, the succession involved exclusively domcstic contacts.

In the case of In re Hess' Will, 120 Misc. 372, 198 N.Y. Supp. 573 (Surr. Ct. 1923), a New York resident executed a will in Gernany and left certain legacies in "inarks." In a proceeding in New York, the domicile of the deceased and situs of the personal property, for the determination of the meaning of the word "marks" the court found that the intention of the testator was to leave to his beneficiaries "gold or silver marks" and not depreciated currency. Reference, therefore, to the law of Germany or that of New York for the construction of the word "marks" was unnecessary.

323200 Misc. 441, 106 N.Y.S.2d 102 (Surr. Ct. 1951).

324 E.g., In re Tallmadge, 109 Misc. 696, 181 N.Y. Supp. 336 (Surr. Ct. 1919).

325 E.g., Rockwell v. Bradshaw, 67 Conn. 8, 34 Atl. 758 (1895) (England); In re Duke's Estate, 181 Misc. 529, 41 N.Y.S.2d 745 (Surr. Ct. 1943) (interstate); In re Tallmadge, note 324 supra.

${ }^{326}$ E.g., In re Stebbins-Vallois' Estate, 99 N.Y.S.2d 402 (Surr. Ct. 1950) ; Ennis v. Smith, 55 U.S. (14 How.) 399 (1852).

327 E.g., Caulfield v. Sullivan, 85 N.Y. 153 (1881).

328 E.g., Cruger v. Phelps, 21 Misc. 252, 47 N.Y. Supp. 61 (Sup. Ct. 1897).

320 E.g., Harrison v. Nixon, 34 U.S. (9 Pet.) 483 (1835) ; cf. In re Kapell's Will, 120 N.Y. S.2d 52 (Sup. Ct. 1952) ; New York Ins. and Trust Co. v. Viele, 161 N.Y. 11, 53 N.E. 311 (1899).

330 While no rational distinction can be made between a will exercising a power of appointment and any other will, see Breslauer, Prrvate International Law of Succession 184 (1937), it is generally accepted that the construction of a will exercising such a power is governed by the law of the donor's rather than the donee's domicile. REstatement, Confuict of Laws § 285 (1934); 2 Beate, Conflict of Laws 1011 (1935); Goodruch, Conflict of Laws 
sues are resolved in accordance with "directory" rules of the local law. . $^{331}$ However, in the difficult case involving foreign contacts the issue of the law governing construction is frequently raised. ${ }^{\mathbf{3 2}}$

533 (1949 ed.) ; StuMrberg, Confuct of Laws 429 (1951). The question arising most frequently is whether a residuary bequest not mentioning the power of appointment exercises the power or not. It is submitted that the courts, as in any other case of construction of wills, try to reach just and reasonable results by taking into consideration both the donor's and the donee's intention and avoiding reliance on inflexible choice-of-law rules. In Cotting v. De Sartiges, 17 R.I. 668,24 Atl. 530 (1892), the donee of a power of appointment over a trust of movables in Rhode Island died shortly after the execution of a will aboard a ship in England. In a proceeding in Rhode Island for the determination of the question whether the power was exercised by the residuary clause by implication, the court held that it was not. This result was reached by application of Rhode Island law, the donor's domiciliary law, requiring inanifestation of express or implied intention for the exercise of the power. Apphication of the donee's domiciliary law (New York) would probably lave led to a result not intended by either the donor or the donee; the court pointed this out by a very careful consideration of all the surrounding circumstances.

In the Matter of Spitzmuller, 279 App. Div. 233, 109 N.Y.S.2d 1 (1st Dep't 1951), aff'd, 304 N.Y. 608, 107 N.E.2d 91 (1952), testator, an American citizen, died in Switzerland having executed a will in Italy. In a proceeding in New York for the construction of the will, the main issue was whether testator exercised a power of appointment over the principal of a trust of movables that he lad settled in that state. Under the situs law of New York there was a rebuttable presumption in favor of the exercise of the power by the residuary clause, and petitioner rehed upon that presumption. It was beld that the power was not exercised. In reaching this decision the New York court stated that "since there is no clain that Otis [the deceased] was ever a resident of this state, the New York statute cannot govern the effect to be given to the provision of the will," and that "the law of the testator's domicile, in the circumstances liere, controls the interpretation and scope of the will." Under both the law of Italy, wbere testator declared he was domiciled, or the law of Connecticut, where the court found that the deceased was domiciled, an affirmative exercise of the power was necessary. The result can be rationalized either on the ground (1) that the testator intended the law of Italy or that of Connecticut to apply or (2) that a proper interpretation of the deceased's intention made reference to rules of construction unnecessary. For the court was eager to state that "whether or not Otis by his will intended to exercise the power of appointment contained in the inter vivos trust is fundamentally one of intention. The intention of the testator is the controlling factor" and that "the inference is clear that the settlor never intended to exercise the power reserved by him in the two inter vivos trusts." See Amerige v. Attorney General, 88 N.E.2d 126, 132 (Sup. Jud. Ct. Mass. 1949): "It has been said that the basis of this principle [application of the donor's domiciliary law] is that the property subject to the power is considered as belonging to the donor. ... But this is not always decisive. The intention, express or presumed, of the donor lias also been considered as a factor of importance." Wilmington Trust Co. v. Wilmington Trust Co., 26 Del. Cl1. 397, 24 A.2d 309 (1942) (interstate); see also In re New York Life Ins. and Trust Co., 139 N.Y. Supp. 695 (Surr. Ct. 1913) (Italy) ; Simonson v. Waller, 9 App. Div. 503, 41 N.Y. Supp. 662 (Sup. Ct. 1896) (England) ; Adams v. d'Hauteville, 72 R.I. 325, 51 A.2d 92 (1947) (Switzerland); Aubert's Appeal, 109 Pa. 447, 1 Atl. 336 (1885) (France); Bancroft v. Bancroft, 68 R.I. 406, 27 A.2d 836 (1942) (England) ; In re Holtorf's Estate, 117 N.Y.S.2d 804 (Surr. Ct. 1952) (Germany); In re de Von der Hallen's Trust, 169 N.Y.S.2d 698 (Special Term 1957) (Argentina) ("Whether the will did or did not exercize a power of appointment is fundamentally one of intention"). Id. at 701.

331 I.e., rules that are applicable only in absence of contrary intention. $C f$. BresLAUER, Private International Law of Succession 119 (1937).

332 The issue is actually raised in cases involving a real conflict of laws, i.e., where the same will may be given different construction under different systems of law. If the will las been already construed abroad and the court merely follows such construction, the issue is not one of choice-of-law. $C f$. text at note 6 supra. 
It is settled law that a testator may designate the law governing construction by express or implied reference. ${ }^{333}$ It is commonly stated that the law of the testator's domicile governs in the absence of any such reference. ${ }^{334}$ The rationale of this rule lies in the assumption that the testator knew or should know the law of his domicile and that his failure to provide for the contingency which happened or for the application of foreign law is an indication that domiciliary law was intended to apply. ${ }^{335}$

This fiction is, perhaps, justified in the ordinary case of succession where contacts with only one country are involved. But, in a multiple contact case of succession, mechanical application of the domiciliary rule would refute its rationale; in such a case, full effect to the intention of the testator may be given only by a choice of law in view of all the surrounding circumstances and apart from fixed principles, fictions, and presumptions. This is

333 In re Kadjar's Estate, 200 Misc. 268, 102 N.Y.S.2d 113, 117 (Surr. Ct. 1950): "Where the testator makes it clear that the will is to be interpreted according to the laws of a given jurisdiction other than his domicile, effect will usually be given to such intention." See also In re Ryan's Estate, 178 Misc. 1007, 36 N.Y.S.2d 1008 (Surr. Ct. 1942) (implied intention that New York situs law govern construction); In re Grant's Will, 200 Misc. 35, 101 N.Y.S.2d 42.3 (Surr. Ct. 1950) (intention that the will of a New York domiciliary be construed in accordance with Australian law) ; Harding v. Shapiro, 120 Md. 541, 87 Atl. 951 (1913) ("... wills of personalty are to be construed according to the law of the testator's donicile at the time of his death, unless it appears on the face of the will that it should be construed with reference to some other law"); In re Coudert, 92 Misc. 109, 155 N.Y. Supp. 145 (Surr. Ct. 1915) ("A will of movables is generally, in the absence of other intention to be governed by the law of the testator's last domicile"); In re Fabbri's Will, 2 N.Y.2d 236, 140 N.E.2d 269 (1957); Estate of Wood, 155 N.Y.S.2d 959 (Surr. 1956); In re Riesenberg's Estate, 116 Mo. App. 308, 90 S.W. 1170 (1905); Harrison v. Nixon, 34 U.S. (9 Pet.) 483 (1835). Cf. 2 Beare, Conflict of Laws 1038 (1935); Brestauer, Private Internationat Law of Succession 128 (1937).

There was previously some doubt with respect to the power of the testator to designate the law governing essential validity of the will, thus abrogating "imperative" or "cogens" rules of the law of his domicile. Cf. BREsLaUER, supra, at 128. This doubt seems removed by the decision in In re Cook's Estate, 204 Misc. 704, 123 N.Y.S.2d 568 (Surr. Ct. 1953), aff'd, 283 App. Div. 1047, 131 N.Y.S.2d 882 (1st Dep't 1954), discussed in text at note 269 supra. Such reference to the law governing essential validity may be made by implication. See $I n$ re TomacelliFilomarino's Estate, 189 Misc. 410, 73 N.Y.S.2d 297 (Surr. Ct. 1947), discussed in text at note 278 sutpra.

${ }^{334}$ See In re Kadjar's Estate, 200 Misc. 268, 102 N.Y.S.2d 113 (Surr. Ct. 1950); 4 PAGE, Wirrs 707 (1941); Annot., 52 A.I.R.2d 490, 491 (1957). Some courts admit the existence of a rebuttable presumption that the testator intended his will to be construed in accordance with the usage at his domicile. See Note, 19 N.Y.U.L.Q. Rev. 216 (1942); Worfr, Private InTERNATIONAT LAW 600 (1945). Where there is a change of domicile between the time of execution of the will and the time of death, some courts apply, in absence of other intention, the law of the domicile at the time of execution. See In re West's Estate, 157 N.Y.S.2d 760 (Surr. Ct. 1956); In re Hirschmann's Estate, 124 N.Y.S.2d 801 (Surr. 1953) ("In as much as decedent and his spouse were residents of Gernany at the date of the execution of the reciprocal testament, the construction of its provisions is not affected by the subsequent change of residence to New York, and German law will accordingly be applied"). Cf., In re Galagher's Estate, 169 N.Y.S.2d 271, 274 (Surr. 1957) (intestate) ; RESTATEMENT, Confuict of LAws $\$ 308$ (1934).

${ }^{335}$ See In re Riesenberg's Estate, 116 Mo. App. 308, 90 S.W. 1170 (1905); In re Fischer's Estate, 66 N.Y.S.2d 69 (Surr. Ct. 1946); In re Angarica's Estate, 157 Misc. 98, 282 N.Y. Supp. 
precisely what the American courts have done; domiciliary formulae have been disregarded and the wills construed in accordance with the law best realizing the intention of the testator, be it domiciliary law at the time of execution of the will or death, or situs and forum law.

Several wills involving international conflicts have been construed according to the law of the testator's domicile at death. In most of them the courts expressly based the applicability of domiciliary law on the express or implied intention of the testator. In one of these, In re Hollins, ${ }^{336}$ a British citizen domiciled in England executed in that country a will disposing of personal property situated in New York. A legatee under the will, domiciled in Austria, objected to a deduction made by the American executors for the payment of a legacy duty to the British Crown. The court granted in principle both the executors' contention that the devolution of the personal property of this testatrix was "primarily governed by the law of her English domicile" and the legatee's exception that American courts should "not aid a foreign country in the enforcement of its revenue laws." The deduction, however, was allowed in accordance with English law on the ground that application of that law would result in a disposition presumably intended. "The court should favor such an administration of the estate here as will be in conformity with the intention of the testatrix," the Surrogate declared. "It certainly was not the intention of the late Duchess that the bequests made by her to the English legatees should be partly confiscated in the payment of death duties imposed upon the bequest to foreign legatees."

In re Kadjar's Estate, ${ }^{337}$ was a case of like import. The deposed Shah of Persia died in France leaving a holographic will executed in that country in which he named his mother beneficiary of a trust of personal property situated in New York, with the direction that upon her death the fund should devolve to her "direct heirs" (heritiers directs). This term had a different meaning under each of the legal systems involved-the law of France, the place of execution of the will and alleged domicile at death; the law of Persia, the nationality of the deceased and domicile of origin; and the law of New York, situs and forum. The court said that "the rule is that a gift to the heirs of a given person is generally determined to pass to those who would constitute that person's heirs according to the law of the domicile of the testator," and proceeded to find a domicile in Persia in spite of the testator's declarations to the contrary and his prolonged stay in France. But the application of Persian law was not based on a mechanical reliance

627 (Surr. Ct. 1935); In re Sewart's Estate, 342 Mich. 491, 70 N.W.2d 732 (1955); Martin v. Eslik, 90 So. 2d 635 (Miss. 1957); cf. note 332 supra; note 388 infra. 83879 Misc. 200, 139 N.Y. Supp. 713 (Surr. Ct. 1913).

837200 Misc. 268, 102 N.Y.S.2d 113 (Surr. Ct. 1950), affd, 113 N.Y.S.2d 245 (1952). 
on the domiciliary rule; the court, instead, declared that it was the testator's "presumed intention" 338 that the term direct heirs be construed in accordance with Persian law, warranting a result most probably intended. ${ }^{330}$

Two additional cases in which application of domiciliary law was based on the intention of the testator merit discussion. Construction of the residuary clause in the will of a French testator with respect to a bond requirement was in issue in In re Coudert. ${ }^{340}$ Were this clause to be construed under the law of New York to which the will owed its validity the universal legatee would be required to give a bond to secure the payment of certain specific legacies; if, on the other hand, the law of France governed no such bond was necessary. "It must be remembered that it is the will of a Frenchman last domiciled in France," the court stressed, and allowed the universal legatee to recover the estate without bond "in absence of other intention" by the testator. And in the well-known Tallmadge ${ }^{341}$ case, testator, domiciled in France, executed a will in New York disposing of personal property situated in that state. He left the residuary estate "share and share alike" to an aunt and a cousin, and disinherited his brother; but the cousin predeceased the testator and the legacy lasped. Under the law of France lapsed legacies swell the residue; were this law to be applied the aunt would receive the fund. Under the law of New York lapsed legacies become intestate property; if that law controlled construction the disinherited brother would receive a windfall against the testator's express intention. In an elaborate opinion, the court held that the law of France governed and awarded the entire residuary estate to the testator's aunt. The decision is particularly significant because the court, in order to reach this result, had to overcome serious legal difficulties. ${ }^{342}$

A second series of international cases-these applying situs law in the construction of wills of foreign domiciliaries-also illustrate the common

338 Id. at $117,120$.

339 The applicability of the law better realizing the testator's intention is evidenced in the instant case by the fact that in an earlier decision construing another portion of the same will, the law of the state of New York was applied. See In re Kadjar's Estate, 200 Misc. 268, 102 N.Y.S.2d 113 (Surr. Ct. 1950).

34092 Misc. 109, 155 N.Y. Supp. 145 (Surr. Ct. 1915).

341 In re Tallmadge, 109 Misc. 696, 181 N.Y. Supp. 336 (Surr. Ct. 1919). See also Rockwell v. Bradshaw, 67 Conn. 8, 34 Atl. 758 (1895) (legacy by Englisb testator to American bencficiary; held, lapsed, in accordance with the intention of the testator); McCurdy v. McCallum, 186 Mass. 464, 72 N.E. 75 (1904) (Nova Scotia).

342 The court (1) decided the issue of formal validity under the situs law since the will was formally invalid under the domiciliary law; (2) construed the will in accordance with the domiciliary law-a law under which the entire disposition was invalid; and (3) denied renvoi as a part of the law of New York and rejected the reference to the "national" law of the deceased made by the domiciliary law. It seems that the court could lave reached the same result by simply "interpreting" the will and avoiding the choice-of-law problem. Cf. text at note 316 supra. 
law choice-of-law rule that construction of wills of movables is governed by the law best realizing the testator's intention. Construction of a clause relating to the payment of inheritance taxes in the will of an American citizen domiciled in Bermuda was the issue in In re Ryan's Estate. ${ }^{343}$ Testatrix directed: "Succession taxes shail be paid from out the residuary estate and shall not be charged against any of the specific bequests, legacies, or devises herein made." There was partial intestacy and the residuary legatee contended that he was charged with taxes only on property passing under the will. It does not appear from the record what result would be reached if Bermuda law were to be applied but under the law of New York which was applied on the ground that such was "the decedent's implied intention" the legatee was charged with taxes for property passing under the will only; all other property included in the taxable estate was charged with a proportionate share. The court explained this result with a statement which can be fairly taken as expressing the present state of the law: "The determinaion here made ... is based solely upon the intent of this testatrix.

Situs law was also applied in the case of In re Stebbins-Vallois' Estate. ${ }^{344}$ An American citizen domiciled in France gave her residuary estate and the principal of a trust over which she had a limited power of appointment to the descendants of a predeceased brother and sister. The exercise of the power failed and only a portion of the fund was placed at the disposal of the executor for re-distribution. In a proceeding for the determination of the persons entitled to distribution, the court awarded the fund to the same residuary legatees according to New York (situs) law, stating that "the facts indicate deceased's intention to have New York law control the validity and effect of the testamentary dispositions." And in the case of In re Firth's Estate, ${ }^{345}$ involving construction of the will of an American citizen domiciled "outside" the United States with respect to the power of the executors to remove assets from the situs jurisdiction, the issue was determined in accordance with the law of New York. Testator had directed that the will "be construed ... by the laws of the state of New Yorl."

Several wills of movables involving foreign contacts other than domicile have been construed in accordance with the law of the situs and forum which coincided with the domicile. Even when these significant contacts

843178 Misc. 1007, 36 N.Y.S.2d 1008 (Surr. Ct. 1942), aff'd, 265 App. Div. 1051, 41 N.Y. S.2d 196 (Sup. Ct. 1943).

84499 N.Y.S.2d 402 (Surr. Ct. 1950).

845205 Misc. 101, 127 N.Y.S.2d 407 (Surr. Ct. 1953). See also In re Grant-Suttie's Estate, 205 Misc. 640, 129 N.Y.S.2d 572 (Surr. Ct. 1954) (implied intention of the testator, Canadian domiciliary, that his will be construed in accordance with the New York (situs) law); In re Fingerhut's Estate, 85 N.Y.S.2d 716 (Surr. Ct. 1948) (construction of will of a Swiss domiciliary under New York situs law); cf. Ennis v. Smith, 55 U.S. (14 How.) 399 (1852). 
coincide the courts do not mechanically apply domestic standards. Quite ordinarily, the entire factual situation is closely scrutinized and local law is applied only in absence of any other express or implied intention. Accordingly, local law was applied in Harrison v. Nixon, ${ }^{340}$ one of the earliest cases in the United States to follow the domiciliary rule, apparently on a finding that it was not "manifest that the testator had the laws of some other country in his own view"; in Houghton v. Brantingham, ${ }^{347}$ since there was "nothing to indicate that she [testatrix] intended that the will should operate according to foreign laws"; in Harding v. Schapiro, ${ }^{348}$ there "being nothing to ... show that the testatrix intended it to be construed with reference to any other law"; and in Caulfield v. Sullivan, ${ }^{340}$ since the application of foreign law "would defeat the testator's manifest intention."

34634 U.S. (9 Pet.) 483 (1835). Testator, a citizen of Pennsylvania, by a will executed in Philadelphia left his enormous estate consisting of personal property situated in Pennsylvania to his "heirs-at-law" or "lawful heirs." He died in England having resided there for more than four decades. The trial court awarded the entire estate to an Englishman as the designated heir under the law of England. The United States Supreme Court (per Joseph Story, Justice) reversed that decision on the ground that "there was no allegation in the pleadings as to the place of the testator's domicile, a matter which, when the case was below, the counsel on both sides and the court, had considered as either sufficiently alleged or of no importance." See 19 Fed. Cas. 876. On remand, "the jury understanding what they did understand, thought they understood everything; and pretty much had decided the case, when they heard it by one side; they found a Pennsylvania domicile." 19 Fed. Cas. 878. As a result, the will was construed under Pennsylvania law. The case is particularly important for Justice Story's dictum that "in regard to personalty, the law of the testator's domicile governs the distribution thereof, and will govern in the interpretation thereof; unless it is manifest that the testator had the laws of some other country in his own view," which was cited with approval in numerous cases recognizing the testator's autonony to select the applicable law in the succession.

84786 Conn. 630, 86 Atl. 664 (1913). A proceeding was initiated in Connecticut, domicihary and situs jurisdiction, for the construction of a will executed in France in the French language and form. The court interpreted the will by looking "to the technical meaning and use in France of the language adopted" and construed it in accordance with the law of Connecticut, the law "presumably" intended by the deceased.

848120 Md. 541, 87 Atl. 951 (1913). An Anjerican citizen domiciled in Maryland, by a will executed in Austria left to her niece a legacy payable "when she attains majority." In a proceeding for the construction of the will it was held that the majority of the legatce should be determined under Maryland law according to the intention of the testatrix - and not Austrian law, the law of the legatee's domicile.

Perhaps the best rationalization of this decision can be found in Holloway v. Safe Deposit Trust Co., 151 Md. 321, 333, 134 Atl. 497, 501 (1926), where the court explained: "[T]he court did not regard the question of the majority of the legatee in that case as one of status at all .... The testatrix wanted her to have the legacy at a given time, viz., when she should arrive at the age of 18 years, the age of the 'majority' of a girl as testatrix knew it . . . It was simply a question of finding the intention of the testatrix...."

34085 N.Y. 153 (1881). New York situs and domiciliary law was applied in the construction of a will executed in France and in French language by an American citizen "tcmporarily residing" in that country. 'Testator left all his property in the United States to his two brothers and his estate in France to his French mistress. When the latter attempted to enforce a contractual claim against the American estate, the court, under New York law, put her to her election and held that acceptance of a gift under the will operated as a satisfaction of the claim. 


\section{Revocation}

According to the domestic laws of most American jurisdictions a will may be revoked by (1) the execution of a subsequent instrument expressly or impliedly revoking the earlier one; (2) physical acts done to the will, such as cancellation, obliteration, tearing, burning, destruction; and (3) by operation of law because of subsequent events which the law presumes to import a revocatory intent, such as marriage, birth of issue, and divorce..$^{350}$ On the conflicts level, it is generally accepted that revocation is governed by the law of the testator's domicile at death. ${ }^{351}$ It seems, however, that the same choice-of-law rules apply to revocation as to the making of wills ${ }^{352}$ and that the law which best gives effect to the intention of the testator governs revocation, whether by subsequent will or by other acts and events.

\section{By Subsequent Will}

Revocation by subsequent will may involve issues of formal validity, essential validity, and construction of the revoking will-just as in the case of any other will..$^{353}$

The subsequent will, whether containing only a revocatory clause or a new scheme of disposition, must be formally valid. ${ }^{354}$ Such validity will be

But this result was not based solely on the applicability of the domiciliary and situs law as such; for the court observed that "it was in the contemplation of the testator that she would either surrender her claims against the estate or obtain satisfaction of them out of his property in France, and it would defeat his manifest intention if the property given to his brothers was to be diminished by the amount of her claim."

See also New York Life Ins. and Trust Co. v. Viele, 161 N.Y. 11, 55 N.E. 311 (1899), where the court said: "In giving construction to the words used by the testatrix in a domestic will, we cannot assume, without the clearest evidence, that she used the words "Iawful issue" in the sense that they might possibly bear in the code of Saxony, or that they might be understood by the Roman civihans"; Pleasant's Appeal, $77 \mathrm{~Pa} .356$ (1875) (Jamaica). In this category of cases, the courts at times apply local (forum, situs, and domiciliary) law without express reference to choice-of-law principles. See In re Bondy's Estate, 203 Misc. 920, 118 N.X.S.2d 93 (Surr. Ct.1952) (will executed in Czechoslovakia by New York citizen sojourning in that country); In re Bell's Will, 141 Misc. 720, 253 N.Y. Supp. 118 (Surr. Ct. 1931) (Ireland); In re Antoni's Will, 186 Misc. 988, 61 N.Y.S.2d 349 (Surr. Ct. 1946) (Germany). Cf. In re Mayer, 84 Misc. 9, 145 N.Y. Supp. 665 (Surr. Ct. 1914) (France); In re Hess' Will, 120 Misc. 372, 198 N.Y. Supp. 573 (Surr. Ct. 1923) (Germany).

${ }^{350}$ See in general Atrinson, Wirts 419-79 (1953). See also Brestauter, Prrvate IntzrNATTONAL LAW OF SUCCESSTON 166 (1937).

351 See Restatement, Confuict of Laws § 307 (1934); 2 Beate, Confutct of Laws 1037 (1935); Goodrich, Confutct of Laws 519 (1949 ed.); 4 Page, Witis 719 (1941); Stumberg, Confuict of LaWs 426 (1951); Wrarton, Conflict of LaWs 435 (1872); WolfF, Private INTERNATIONAL LaW 604 (1945); Annot., 9 A.L.R.2d 1412, 1414 (1950).

352 See text at notes 87,103 supra.

353 Cf. Brestauter, Private InTernational Law of Succession 166 (1937); WolfF, Private InTERnatignar, Law 604 (1945). See in general, Evans, Testamentary Revocation by Subsequent Instrutment, 22 Ky. L.J. 469 (1934); Note, 123 A.L.R. 1395 (1939).

354 See In re Logasa's Estate, 161 Misc. 774, 293 N.Y. Supp. 116 (Surr. Ct. 1937) ("The reason that exists for requiring that a will to be effective inust be executed with certain formali- 
determined in accordance with the already discussed choice-of-law rules governing formal validity of wills in general. ${ }^{355}$ Thus, in In re de Garmendia's Estate, ${ }^{358}$ an American testatrix domiciled in Maryland, having already executed a valid will in France, executed a second instrument in Germany containing new bequests of personal property. The latter instrument was holographic but, except for an indorsement on the back of the sheets-"This will was made in Nayheim August 22, 1922. My last wishes"-it was neither signed by testatrix nor witnessed. A beneficiary under the second instrument sought to establish it in Maryland as a valid will and contested the probate of the earlier French will on the ground that it had been revoked. The court, relying mostly on the intention of the testatrix, ${ }^{357}$ held that the French will was valid and unrevoked and denied effect to the second instrument which was formally invalid under both the law of Maryland and that of Germany. And similarly, in In re Logasa's Estate, ${ }^{358}$ an American citizen domiciled in New York executed a will in the French form in France and subsequently another instrument in New York attested by only one witness and containing entirely contradictory provisions. Interested parties contested the probate of the French will in New York alleging that it was revoked by the second instrument which constituted a valid revocation under French law. ${ }^{350}$ The Surrogate admitted to probate the French will and denied affect to the subsequent instrument

ties exists to an equal extent for requiring that an instrument revoking a will to be effective inust be executed with like formalities. Formalities in the making and in the revocation of a will are necessary to prevent mistake, misapprehension, and fraud").

355 Roman II, subpart $A$ of text beginning at note 87 supra.

356146 Md. 47, 125 Atl. 897 (1924).

$357 \mathrm{Cf}$. id. at $53,125 \mathrm{Atl}$. at 899 . "Any incompleteness in such a paper is naturally taken as an indication that the testator did not finally adopt the paper as bis will . . . . The paper offered for probate in this case bears on its face declarations by the decedent that it was not yet signed as she intended to sign it; that it was to be executed at some later time, not yet so fixed that the date could be inserted; and that her signing it in the place she bad prepared for signing, and now left blank, was to be witnessed and the signatures of the witnesses appended in a place designated and likewise now left blank."

358161 Misc. 774, 293 N.Y. Supp. 116 (Surr. Ct. 1937).

359 This second instrument was holographic and attested by only one witness. As it was then invalid under New York law either as a will or as a revocation, interested parties sougbt to establish its vahity under French law relying upon Section 34 of New York Decedent Estate Law which provided that "a will may be revoked ... by some other writing . . . executed with the same formalities with which the will itself was required by law to be executed." The Surrogate declared flatly that "this section admits to no such interpretation." Obviously, French law was irrelevant since its only contact with the succession was the execution of the original will in France.

See also Rabe v. McAllister, note 367 infra; Ennis v. Smith, note 368 infra (formal validity of revocatory instruments determined according to the law of the place of execution); $c f$. Kelley v. Sutliff, 262 Ala. 622, 80 So.2d 636 (1955) (situs law); Estate of Lufkin, 32 Hawaii 826 (1933) (will of Hawarian domiciliary executed in Hawaii and disposing of Hawaiian property; held, formally invahid; earlier will executed in California not revoked). 
which was formally invalid under the law of the place of execution, the domiciliary law of the testator, and the situs and forum law.

In addition to the requirement of formal validity, according to the prevailing view, a subsequent will containing entirely inconsistent provisions must also be essentially valid in order to effect a revocation of the earlier will. ${ }^{300}$ This issue of essential validity may be raised because of the doctrine of dependent relative revocation prevailing in most common law jurisdictions; ${ }^{301}$ in those jurisdictions an earlier will is not revoked if the last will cannot be carried into effect. ${ }^{302}$ While no international case has been found on the precise point, it seems probable that the issue of essential validity of a revocatory instrument, if raised in the future, will be deternnined in accordance with the choice-of-law rules governing essential validity of wills in general. ${ }^{363}$

Problems of construction are frequently raised when a formally and essentially valid subsequent instrument, thougl not expressly revoking the earlier will, contains provisions wholly or partially inconsistent with those previously made. Thus, in In re Hug's Estate, ${ }^{304}$ testator died domiciled in Switzerland. He left one will executed in the United States disposing of assets situated in New York, and a second will executed in Switzerland which "did not in express ternns revoke any other will or make reference to any other testamentary instrument." Testator's son initiated proceedings in New York to vacate the probate of the American will, alleging that under Swiss domiciliary law the execution of a subsequent will containing inconsistent provisions operated as a revocation of any other previous will. The court, relying on the intention of the testator rather than on Swiss domiciliary law, ${ }^{305}$ denied the petitioner's claim and held that the American will was not revoked.

When the revoking will is itself subsequently revoked, it may be a matter of construction whether the earlier will is revived. ${ }^{336}$ In Rabe $v$.

300 See PAGE, WIIS 893 (1941); ArkINSON, WIIrs 462 (1953). If there is an express clause of revocation, however, the subsequent instrument need not be essentially valid. See Jararas, WrIIS 183 (1951); PAGE, WIIS 888 (1941); ATKINSON, WIIIS 461 (1953).

301 See in general Warren, Dependent Relative Revocation, 33 HaRv. L. Rev. 337 (1920);

Evans, Dependent Relative Revocation, $16 \mathrm{Kx}$. L.J. 251 (1928).

382 See ArkInson, WIrrs 462 (1953); PAGE, WIIrs 893 (1941).

803 Discussed in Roman II, subpart $B$ of text following note 103 supra.

384201 Misc. 709, 107 N.X.S.2d 664 (Surr. Ct. 1949), affd, 134 N.Y.S.2d 591 (1st Dep't 1954).

365 See 107 N.Y.S.2d at 673. "On the question of revocation of the 1934 will, the experts produced by both sides are in disagreement .... The question inust be whether the decedent intended the 1940 will to govern all of his property wherever located or only property not disposed of in the American will ... . Petitioner has failed to establish reasonable probability of success on the question of revocation."

306 This is the rule at least in those jurisdictions that follow the so-called doctrine of the ecclesiastical courts. See Arknvson, Wris 475 (1953); Note, 29 Mrce. L. Rev. 1031 (1931). 
McAllister, ${ }^{367}$ testatrix, while domiciled in Maryland, executed a will disposing of her entire estate situated in that state. She subsequently moved to Germany and executed a second will revoking the first, and a third revolsing the second. No heirs or legatees were instituted in the last will and the Maryland court was confronted with the issue of revival of the first will. The court did not dwell on the issue of the applicable law since, according to a Maryland statute, Maryland law was applicable in the succession regardless of deceased's domicile abroad; it held that the first will was revived. This result, however, was not reached by a mechanical application of the situs and forum law. The court explained that "the question, as to revival of a previous will, thus appears to be reduced to one of fact dependent on all the evidence going to show the testator's intention, and not one of legal presumption," and concluded that "the ruling ... is supported under the circumstances by the evidence of the testatrix's intention to revive it by the express revocation of the second will."

In contrast, no issue of revival was raised in Ennis v. Smith. ${ }^{308}$ General Kosciusko, the War of Independence hero, made four wills. The first, executed in the United States and disposing of assets situated in this country, was subsequently revoked by a will executed in Paris. This second will was revoked by a third one executed in Switzerland, and the latter by a fourth will also executed in Switzerland. In a proceeding before the United States Suprenie Court for the determination of the liability of the executors and the persons entitled to indemnity it was held that General Kosciusko died intestate as to his assets in the United States since neither the third nor the fourth will included a residuary clause.

\section{By Acts and Events}

Revocation by physical acts done to the will and by operation of law because of subsequent events and changes in the circumstances involves, in essence, a problem of construction. The law attributes to those acts and events an intention to revoke; but a contrary intention, if established, is often given effect. Similarly, in a multiple contact case, the courts appear to be guided by the intention of the testator rather than his domiciliary law. ${ }^{369}$ Thus, in Senac's Succession, ${ }^{370}$ testator, while domiciled in Louisiana, made a will disposing of personal property situated in that state. He subsequently married and sailed to France, intending to reside permanently

867177 Md. 97, 8 A.2d 922 (1939).

80855 U.S. (14 How.) 399 (1852).

369 Cf. In re Traversi, 189 N.Y.S.2d 453 (Surr. Ct. 1946) (place of revocation, domicile at time of revocation).

370 2 Rob. 258 (La. 1842); cf. Caballero v. the Executor, 24 La. Ann. 573 (1872), note 264 supra; In re Tomacelli-Filomarino's Estate, 189 Misc. 410, 73 N.Y.S.2d 297 (Surr. Ct. 1947), note 278 supra; In re Feuerinann's Will, 47 N.Y.S.2d 738 (Surr. Ct. 1944), note 276 supra. 
there. In the following years a child was born in the marriage and the testator died. When legatees under the will sought possession of the estate in Louisiana the widow contested the probate on the ground that the birth of the child revoked the will. Indeed, under the laws of Louisiana, the subsequent birth of issue had such an effect, but under the domiciliary law at death-the law of France-the will continued valid and unrevoked. The court, relying on what it thought to be the intention of the testator and disregarding the domiciliary law, declared that the will had been revoked. "This provision of our code," the court said, "is founded on the presumption that the testator would not have made such a will, had he forseen that he would thereafter have children. If, as has been remarked, the testator did not revoke this will during the sixteen months that he survived the birth of his child, it is fair to presume that it was because he knew that by the law of Louisiana, under which it was made, it had become a nullity by the birth of such child."

Similarly, in In re Barnhart's Will, ${ }^{371}$ an American citizen domiciled in Canada, executed a will in New York the day following his second marriage disposing of personal property situated in that state. He made some legacies in favor of his children of the first marriage and left the residue of his estate to his second wife. Three children were subsequently born in the second marriage; upon the death of the testator, a special guardian sought a determination in New York that the will was revoked as to these children. The court agreed with the guardian's legal theory that New York law governed but denied any rights to the after-born children on the ground that deceased had no estate in New York but merely a power of appointment over property belonging to his father. Relying on this legal technicality, the court was able to give effect to the testator's wishes to leave nothing to his after-born children, evidenced by the fact that the will was executed "in contemplation" of the birth of children. ${ }^{372}$

371137 Misc. 518, 244 N.Y. Supp. 130 (Surr. Ct. 1930).

372 See also Rhode Island Hospital Trust Co. v. Anthony, 49 R.I. 339, 142 Atl. 531 (1928) (will not revoked on the ground that Rhode Island pretermitted heir statute did not cover property subject to a power of appointment) ; Pitman v. Pitman, 314 Mass, 465, 50 N.E.2d 69 (1943) (will exercising power of appointment not revoked by subsequent marriage, under the donor's domiciliary law); cf. Amers v. Duryea, 6 Lans. 155 (1871), aff'd, 61 N.Y. 609 (1874); In re Witter's Estate, 15 N.Y. Supp. 133 (Surr. Ct. 1891); Matter of Brown, 133 Misc. 457, 233 N.Y. Supp. 145 (Surr. Ct. 1929) (wills not revoked under the applicable domiciliary, same as situs, law) ; In re Dennis' Estate, 98 Vt. 424, 129 Atl. 166 (1925); In re White's Will, 112 Misc. 433, 183 N.Y. Supp. 129 (Surr. Ct. 1920); Will of Wehr, 247 Wis. 98, 18 N.W.2d 709 (1945); In re Patterson's Will, 64 Cal. App. 643, 222 Pac. 374 (1923) ; Barnes v. Graves, $259 \mathrm{Ky} .180$, 82 S.W.2d 297 (1935); Lee v. Monks, 318 Mass. 513, 62 N.E.2d 657 (1945); Cornell v. Burr, 32 S.D. 1, 141 N.W. 1081 (1913) (no revocation by marriage, under the domiciliary law); In re Revard's Estate, 178 Okla. 524, 63 P.2d 973 (1936) (will revoked under situs law); In re Parham's Succession, 11 La. 646 (1856) (will revoked under domiciliary, same as situs, law). 


\section{III}

\section{POLICY BASES OF THE RULE AND LIMITS OF ITS APPLICATION}

Writers and courts are in agreement that it is "generally" the law of the testator's domicile at death that governs succession to personal property. But concerning the nature ${ }^{373}$ and the policy bases of that choice-oflaw rule, there is a sharp conflict of opinion.

\section{A. Quest for Uniformity}

Professor Beale and the Restatement have rationalized the domiciliary rule as a quest for uniformity, convenience, and distribution of the entire estate wherever situated according to a single standard. ${ }^{374}$ Uniformity proved to be a day-dream in the international situation ${ }^{375}$ and its pursuit in the interstate conflicts seeins to have disappointed even modest aspirations. ${ }^{378}$ Single administration is practically never achieved; ancillary ad-

373 Lorenzen regards the domiciliary rule in cases of succession as "personal law" in essence. See Lorenzen, Territoriality, Public Policy, and the Conflict of Laws, 33 YaLE L.J. 736, 738 (1924). Beale suggests that this rule is not a conflicts rule at all, but a part of the internal law of the forum. See 1 Beare, Conflict of Laws 58 (1935). Goodrich, Stumberg, and the Restatement seem to assume that the domiciliary rule is a conflict principle of the situs. See Goodricrr, Conflict of Laws 504, 512 (1949); Stumberg, Confrict of Laws 412 (1951); Restatement, Confuicr of LAws $\$ 306$, comment $a$ (1934). Briggs, in a series of articles tried to prove that the famous rule is in effect twofold; a "jurisdictional" rule at the highest level under which the forum recognizes the exclusive power of the situs to delimit interest in tangibles, and a choiceof-law rule at the secondary level by which the situs refers to the law of the foreign domicile to effectuate its own particular policies regarding the matter litigated. Sce Briggs, The Dual Relationship of the Rules of Conflict of Laws in the Succession Field, 15 MIss. L.J. 77,79 (1943) ; Briggs, "Renvo" in the Succession to Tangibles: A False Issue Based on Faulty Analysis, 64 Y ALE L.J. 195 (1954). Briggs' effort aimed at reconciling the broad judicial language, declaring that the law of the domicile governs succession, with the actual apphication of the situs law in several instances. He demonstrated "the existence of two different conflict of laws rules applying at one and the same time to the problem of succession," and concluded that those two rules (that the law of the situs "controls" succession while the law of the domicile "governs"), are "fundamentally incompatible with each other, or they serve basically different purposes." 15 Miss. L.J. 77, 79 (1943). The search for a general principle explaining all problems of succession, and his attempt at reviving the concept of "legislative" jurisdiction, are the main difficulties with Briggs' analysis. Cf. Coor, The LogrCar and Legar BASEs of the CoNFlicr of Laws 71 (1949); Ehrenzweig, American Conficts Law in Its Historical Perspective, 103 U. PA. L. REv. 133, 141 (1954).

374 See 2 Beale, Conflict of Laws 1029, 1030 (1935); Restatement, Confuict of Laws, Introductory Note to the Chapter on Administration of Decedents' Estates 560 (1934). See also Goodrich, Conflict of Laws 504, 512 (1949 ed.); Liverarore, Dissertations on the ConTRARIETY OF LaWs 133 (1823); StORY, CONFLict OF LAWS 317 (1st ed. 1834); Stumbero, CONFLict of Laws 412 (1951).

375 See Coor, The Logical and Legat, Bases of the Conflict of Laws 242, 244 (1949). Cf. Niboyet, Droit Internationat, Privé 594 (1945).

376 The volume of hitigation, and the number of conflicting judgments in different states with respect to the distribution of the same estate, leaves little room for optimism. $C f$. Hopkins, The Extraterritorial Effect of Probate Decrees, 53 YaLe L.J. 221, 233 (1944). Uniformity is also difficult to achieve duc to the fact that each forum is free to "localize" domicile by independent consideration. Cf. Cormack, Renvoi Characterization, Localization, and Preliminary Question in the Confiict of Laws, 14 So. CaLF. L. REv. 221, 242 (1941). 
ministration is opened in any jurisdiction in which assets belonging to the estate are found; ${ }^{377}$ and whether ancillary or not, the administration is subject to burdensome procedures, expenses, and inconveniences. And, while consistent application of the domiciliary rule would, perhaps, lead to distribution according to a single standard in the international or interstate level, it would clearly result in distribution according to double standards within the state whenever the estate of a non-resident would consist of both personal and real property. ${ }^{378}$

\section{B. International Law}

Several courts, especially in the past century, have applied the domiciliary rule as a part of the "law of nations," based on "comity." 379 However, nobody would seriously argue today that this rule derives from public international law; and while "comity" language, in the sense of courtesy rather than legal obligation, still persists in some decisions, most courts are aware that "comity" in the conflicts is ouly a useful tool, and nothing more than an expression of judicial reverence to the law of a foreign sovereign when otherwise applicable. Actually, the problen today is whether the forum, free from compulsion deriving from international treaties, can apply to the distribution of local property the law that would best conform with its domestic and conflict policies. "Comity" at the expense of the lawful expectations of the beneficiaries, the wishes of the deceased, and the forum policy cannot be rightly regarded as a sound basis for the formulation of choice-of-law rules.

\section{The Intention of the Testator}

Numerous decisions declare the policy basis of the domiciliary rule to be succession according to the intention of the testator. The very first court which introduced this rule in the United States declared: ${ }^{380}$

It is supposed that every man is best acquainted with the law of his coun try, and when he dies intestate, it is his desire that his personal property,

377 Cf. text at note 73 supra.

378 This because according to well-settled conflicts rules testamentary succession to real property is governed by the law of the situs. See Goodrich, CoNfLICT OF LAws 505 (1949); Strarberg, Confuict of Laws 409 (1951). Adoption of the same rule with respect to movables might promote the achievement of uniformity within the state. But, at the same time, the situs rule would leave hittle room for judicial discretion. Situs of tangibles is readily ascertaimable by objective criteria, while domicile due to the intervening subjective element proved to be a resilient connecting factor, adjustable to factual situations and enabling the courts to reach results according to the testator's intention.

379 See, e.g., Parsons v. Lyman, 20 N.Y. 103 (1859); Higgins v. Eaton, 202 Fed. 75, 77 (2d Cir. 1913) ("The general rule exists between states and is international. But its recognition depends altogether on comity"); Dammert v. Osborn, 140 N.Y. 30, 35 N.E. 407, 409 (1893). See note 58 supra.

980 Desesbats v. Berquier, 2 Am. Dec. 448, 450 (Pa. 1808), text at note 59 stupra. 
wherever situated, should be distributed according to that law; and to gratify this reasonable desire, it is the practice of civilized nations to extend their courtesy toward each other so far as to permit the law of the domicile of the interstate to prevail.... If this is the rule in case of intestacy why should not the same rule prevail with respect to last wills?

\section{The Supreme Court of Washington observed: ${ }^{381}$}

Various reasons have been given for this rule but none seems to us more satisfactory than that the testator is presumed to be familiar with the laws of his domicile; to have prepared his will in the light of those laws, and to apply any other law would be at great risk of defeating his intent, unless it is manifest that the testator had the laws of some other place, or country, in view.

\section{And the New York Surrogate declared that: ${ }^{882}$}

The basis of this rule is usually the presumed intent of the testator.

It is submitted that this is the true policy basis of the domiciliary rule; it justifies the adoption of the celebrated rule, sets the limits of its application, explains the results reached by the American courts in all international cases of succession to movables, and underlies the actual common law choice of law rules governing formal and essential validity, construction, and revocation.

Deriving thus from the fundamental common law policy favoring testamentary freedom, ${ }^{383}$ and the ubiquitous consideration that the intention of the testator is the guiding star in carrying into effect the disposition, ${ }^{384}$ and clearly not "imperative" but "permissive" in essence, the domiciliary rule aims at the integration of the testator's intention and comes into operation only where no other intention can be gathered. But since "most of the cases from which the principle has emerged had nothing to do with the situations in whicli the deceased had evidenced a contrary intention ...., sight is sometimes lost of the fact that the choice of which law should control always remained with the testator." ${ }^{385}$ As a result, distinction is made

381 In re Chappell's Estate, 124 Wash. 128, 131, 213 Pac. 684, 685 (1923).

382 Matter of Kadjar, 200 Misc. 268, 272, 102 N.Y.S.2d 113, 118 (Surr. Ct. 1950).

383 The right to dispose of property by will came to be regarded as a "natural" right. Munnemacher v. State, 129 Wis. 190, 108 N.W. 627 (1906); Noel v. Ewing, 9 Ind. 37 (1857). See also Smith v. Smith, 48 N.J. Eq. 566 (social compact); In re Estate of Moore, 114 Ore. 444, 236 Pac. 265 (1925) (an attribute of property); Ball v. Boston, 153 Wis. 27, 141 N.W. 8 (1913) (one of the most important of the inherent incidents of human existence). Cf. note 235 supra.

384 See note 372 supra.

385 In re Cook's Estate, 204 Misc. 704, 123 N.Y.S.2d 568, 570 (Surr.Ct. 1953), aff'd, 283 App. Div. 1047, 131 N.Y.S.2d 882 (1st Dep't 1954). Cf. Cook, Tre Logicar and LeGaI Baseg OF THE CONFLICT OF LAwS 244 (1949). This choice is not unlimited. As in cases involving selection of the applicable law to contractual agreements, reasonable connection with the country whose law is selected seems necessary. See In re Rosenbergers' Estate, 131 N.Y.S.2d 59 (Surr. 
in theory between construction and validity of the disposition; and it is urged that, in contrast to construction where the domiciliary rule serves only as a "guide," 386 the validity of the disposition is always determined according to the testator's domiciliary law.

This distinction, which completely disregards the true rationale of the domiciliary rule, was rejected when the proper cases appeared before the courts. Characteristically, the Supreme Court of Washington declared: ${ }^{387}$

We perceive no logical reason why this rule [that domiciliary law is applicable only in absence of other express or implied intention] should not apply to distributions as well as to interpretation, and for the same reasons, since the ultimate purpose in either case is to cause the estate to be distributed as the testator intended.

Other courts, while less outspoken, have consistently determined the validity of the disposition of local movables according to policy-oriented choiceof-law rules rather than immutable principles. In view, however, of the deeply rooted belief in the applicability of the domiciliary rule as an imperative in cases involving validity of disposition, a brief analyses of the policy problems confronting the American forum in such cases is here necessary.

First, whenever the will is valid, or invalid, under all systems having contacts with the succession there is no conflict and in effect no problem. If the will is invalid the personal property will devolve according to the rules governing intestate succession. If the will is valid distribution will be made according to its provisions; it little matters whether it is said that the choice-of-law rule of the forum refers the issue of validity to the law of the domicile of the testator, that of the forum and situs, or any other law. This seems to be the case in most instances of interstate conflicts where the uniformity of domestic laws is such that the result would be the same under any law. ${ }^{388}$ But in the international conflicts field the disposition is fre-

Ct. 1954). See also Wilmington Trust Co. v. Wilmington Trust Co., 26 Del. Ch. 397, 24 A.2d 309, 313 (1942): "[T]here is no sufficient reason why the donor's choice should be disregarded if his intention in this respect can be ascertained from an examination of attendant facts and circumstances, provided, that the same substantial connection between the transaction and the intended jurisdiction shall be found to exist."

386 Matter of Kadjar, 200 Misc. 268, 102 N.Y.S.2d 113, 117 (Surr. Ct. 1950). Cf. text at notes 333,335 supra.

387 In re Chappell's Estate, 124 Wash. 128, 213 Pac. 684, 685 (1923). See also Equitable Trust Co. v. Ward, 29 Del. Ch. 206, 48 A.2d 519 (1946): "Unless a contrary intent appears, the essential validity of a bequest of personal property, whether in trust or otherwise, is governed by the same rule [i.e., law of domicile]." In re Fabbri's Will, 2 N.Y.2d 236, 140 N.E.2d 269,271 (1957) ("at the time of death testator was domiciled in Maine and since no contrary intent appears in the will, the law of that state determines the validity and effect of the will with respect to the disposition of personal property.").

388 Cf. In re Fabbri's Will, 2 N.Y.2d 236, 140 N.E.2d 269 (1957). 
quently valid under one system of law and invalid under the other; consequently, the American forum is confronted with a conflict of policies.

Second, whenever the will is valid under the forum and situs law and invalid under the domiciliary law of the testator, the Restatement seems to suggest that for the sake of uniformity, convenience, and distribution according to a single standard, the testamentary disposition should fail. But the policy underlying the domiciliary rule seems to limit the applicability of foreign law to the extent that the testamentary scheme is valid under that law. ${ }^{389}$ Foreign law, invalidating the will and resulting in intestacy contrary to the wishes of the deceased, can no longer be regarded as "presumably" intended. ${ }^{380}$ Accordingly, the disposition is given effect, at times by express reference ${ }^{301}$ and at times by various devices and techniques, ${ }^{302}$ under the liberal forum and situs law.

Third, a different policy problem confronts the situs courts whenever the testamentary instrument, were it a purely domestic will, would be declared invalid. Invalidity under the forum and situs law, unlike validity, does not predicate a certain and definite result. The solution in the particular case seems to depend on the reason of invalidity and on an evaluation of conflicts and domestic policies.

If the instrument is invalid under the forum and situs law merely due to non-compliance with formal requirements for the execution of wills, the disposition will be given effect if the will is formally executed according to the law of the domicile of the testator or that of the place of execution. Common law courts, favoring testamentary freedom and placing the emphasis on the intention of the testator, are generally inclined to give effect

389 A purely dounestic will in such a case would be carried into effect. The problem, therefore, for the situs court is whether effect should be denied to the instrument not for any other reason but because of the intervening foreign element-the domicile of the testator abroad. In numerous instances wills invalid under the domiciliary law of the testator were saved by a reference to the forum and situs law and in only one case a will, vahid under the law of the situs and forum, was denied effect because of a contrary domiciliary law. See Desesbats v. Berquier, text at note 59 supra.

390 This explains why domiciliary law is applied more frequently in cases involving construction than validity of the disposition. Cf. notes $97,103,258,336$ supra. Construction does not involve a choice between testamentary succession and intestacy, but whether a ccrtain result will be achieved withim the testamentary scheme. Cf. text at note 312 sicpra. Application of domiciliary law in such cases can be reasonably calculated to give results in the hight of the testator's intention.

301 See notes 97, 180, 181, 269, 278, 381, szlpra. Cf. Higgins v. Eaton, 202 Fed. 75, 78 (2d Cir. 1913). "The state of New York with respect to personal property within its territory declines to be bound by the rule of comity and permits independent proof of a testamentary disposition of such property notwithstanding that such disposition may be void according to the law of the decedent's domicile." (Emphasis added.) See also Annot., 52 A.L.R.2d 490, 491 n. 4 (1957) : "The general rule that the law of the testator's domicile governs is itself a qualified principle, applicable only to the extent that it will give effect to the intention of the testator."

892 See notes $91,120,266,290,307$ supra. 
to a testamentary disposition once the forum policy underlying the requirement of form is satisfied-when the court has before it an instrument expressing the testator's free will and seriously intended to become a testament. ${ }^{393}$

Whenever the will is essentially invalid according to domestic standards, the policy of the situs (and forum) allowing a foreign testator to designate his domiciliary law to govern succession would conflict with that underlying the domestic prohibition. If the latter embodies a strong policy of the forum, the disposition, in spite of compliance with the domiciliary law of the testator, will be declared invalid and intestacy will result. ${ }^{394}$ But it may be that the forum law was designed to apply to domestic wills exclusively or to property which would remain within the jurisdiction; in such a case the disposition will be carried into effect according to the law of the testator's domicile. ${ }^{395}$

\section{SUMMARY OF CONCLUSIONS}

The preceding analysis of all reported international cases in the United States has shown that the American courts apply, in the determination of

${ }^{303}$ See In re Rubens' Will, 128 App. Div. 626, 630, 112 N.Y. Supp. 941, 944 (1st Dep't 1908). "We are dealing in this section with ... the question of the authenticity of the expression of the last will and testatment of the decedent. Upon what proof will our courts say that an instrument is the true expression of the dead man's wishes? First, and in any event, we will accept it if executed according to our laws, which we have determined sufficiently safeguard the authenticity of the instrument; second, if the will was made in certain specified countries, if executed according to their laws; and thirdly, if of a nonresident, according to the laws of his residence."

394 In extreme cases the apphicability of foreign domiciliary law is limited by the reservation of public policy of the forum. See Nusssaum, PrdnctPLes of PrTvate INTERNationac LAw 110 (1943). Remarkably few wills, however, have been declared invalid as against public policy. See Laube, Right of a Testator to Pauperize His Helpless Dependents, 13 CoRNELI L.Q. 559 (1928). Cf. Cruger v. Phelps, 21 Misc. 252, 47 N.Y. Supp. 61 (Sup. Ct. 1897).

395 Cf. Dammert v. Osborn, 140 N.Y. 30, 35 N.E. 407, 409 (1893). "It would be contrary to the principles of common justice and right upon which the [domiciliary] rule is founded to permit a testamentary disposition of personal property, valid by the law of the domicile, to be annulled or questioned in every country where jurisdiction was obtained over the property disposed of, or the parties claiming it, except for the gravest reasons." This fully complies with the practice of the courts to decide in favor of the will. See Succession of Meunier, $52 \mathrm{La}$. Ann. Rep. 79, 26 So. 776 (1899) ("The courts lean to upholding of the disposition made by testators of their estates"); In re Bell's Will, 141 Misc. 720, 253 N.Y. Supp. 118 (Surr. Ct. 1931) ("The court will, if possible, adopt that one of two possible interpretations which will give validity to the testamentary direction, rather than one that would make it invalid"); In re Lachenmeyer's Estate, 144 Misc. 678, 258 N.Y. Supp. 641 (Surr. Ct. 1928) ("One of the best known principles is that, if two or more constructions are reasonably possible, the one that will sustain the validity of the will, is to be preferred, generally speaking, to the one that will defeat it.... The court struggles to preserve, and surrenders to nothing short of obvious compulsion. In the attainment of this end, it may reject words and limitations, supply thend or transpose them, to get at the correct meaning." Thus, recognition of the testator's autonomy to designate the applicable law, and application of the law validating the disposition in absence of other express intention, is not an anomaly. It actually involves an interpretation of the testator's intention with respect to the applicable law. 
inheritance rights over local personal property, the law which gives full effect to the intention of the testator in accordance with the forum policy favoring freedom of disposition.

1. Formal validity is determined on the basis of a broad choice-oflaw including, the law of the place of execution, the law of the domicile of the time of execution or death, and the situs and forum law.

2. Essential validity is ordinarily determined according to the law that would save the disposition rather than render it invalid. Accordingly, capacity to dispose and to receive, may be governed by the law of the testator's or the beneficiary's domicile; the validity of a charitable bequest, by the law of the testator's domicile, the law of the place where the charitable bequest is to take effect, or the law of the charitable legatee's domicile; the validity of a will creating trusts and other unknown or forbidden interests, by the law of the place where the trust is to be administered, the testator's domiciliary law, or the situs of the trust estate; and forced heirship, with the exception of the interest of the surviving spouse, may be governed by the liberal law of the common law situs and forum jurisdiction.

3. Interpretation involves a question of fact and hardly a choice-of-law problem. Construction, which may involve a choice-of-law problem, is ordinarily governed by the law best realizing the intention of the testator in view of all the surrounding circunistances. In absence of express or implied designation of the applicable law, domiciliary law may be applied as presumably intended.

4. Revocation by subsequent will, physical acts or operation of law involves primarily a question of intention. Issues of formal validity, essential validity, interpretation and construction of the revocatory instrument, are determined according to the choice-of-law rules governing wills in general. Revocation by physical acts and operation of law involves an issue of construction and is governed by choice-of-law rules, similar to those governing construction.

Since, ordinarily, no articulate distinction is made between interstate and international conflicts cases, an inference could, perhaps, be drawn that the law which gives full effect to the intention of the testator governs succession to movables, in both the interstate and the international situation. Such a generalization should be avoided prior to a careful investigation of the "actual doing" of the courts in cases involving exclusively interstate contacts. Underlying policies differ; and it may be that different choice-oflaw rules govern each field of conflicts. 


\section{California Law Review}

MEMTBER NATIONAL AND WESTERN CONFERENCES OF IAW REVIEWS

Published Five Times Yearly by Students of the School of Law of the

University of California, Berkeley, California. Indexed in Index to Legal Periodicals and Public Affairs Information Service.

\section{Subscription Price, $\$ 6.00$}

Current Single Copies, $\$ 2.00$

\section{BOARD OF EDITORS}

Artaur O. Arasstrong, Jr.

Editor

\section{Chardes A. Minter \\ Assistant Editor}

Davio D. Watelet

Managing Editor

JOFn E. BRECKENRIDGE

Malcolar S. Burnstent

Mrues A. Cobb

Georg Geiger

PaUt W. HartLofs, Jr.
Broce M. Cowax

Article Editor

Edarumd L. Regatia

Book Review Editor

Associate Editors

WIITAAK L. HUGHES

HaROLD C. NachtrIEB

Sheldon C. St. Clatr

Jan S. Stevens

HOWARD M. WEISER

Anne Hosuray

General Secretary

\section{Contributors}

E. MUtes HaRveY

Chartes H. Jaruis

K. D. Lyders
H. Michaer PeccorinI

Norman H. RaIDEN

Davio D. WAIELEY

Theodore Zmameraman 